\title{
Bacterial and fungal infections: evolving towards molecular pathogen diagnostics
}

Citation for published version (APA):

Hansen, W. L. J. (2012). Bacterial and fungal infections: evolving towards molecular pathogen diagnostics. [Doctoral Thesis, Maastricht University]. Maastricht University. https://doi.org/10.26481/dis.20120620wh

Document status and date:

Published: 01/01/2012

DOI:

10.26481/dis.20120620wh

Document Version:

Publisher's PDF, also known as Version of record

\section{Please check the document version of this publication:}

- A submitted manuscript is the version of the article upon submission and before peer-review. There can be important differences between the submitted version and the official published version of record.

People interested in the research are advised to contact the author for the final version of the publication, or visit the DOI to the publisher's website.

- The final author version and the galley proof are versions of the publication after peer review.

- The final published version features the final layout of the paper including the volume, issue and page numbers.

Link to publication

\footnotetext{
General rights rights.

- You may freely distribute the URL identifying the publication in the public portal. please follow below link for the End User Agreement:

www.umlib.nl/taverne-license

Take down policy

If you believe that this document breaches copyright please contact us at:

repository@maastrichtuniversity.nl

providing details and we will investigate your claim.
}

Copyright and moral rights for the publications made accessible in the public portal are retained by the authors and/or other copyright owners and it is a condition of accessing publications that users recognise and abide by the legal requirements associated with these

- Users may download and print one copy of any publication from the public portal for the purpose of private study or research.

- You may not further distribute the material or use it for any profit-making activity or commercial gain

If the publication is distributed under the terms of Article $25 \mathrm{fa}$ of the Dutch Copyright Act, indicated by the "Taverne" license above, 


\section{Bacterial and fungal infections: evolving towards molecular pathogen diagnostics}

Wendy Hansen 
ISBN 978-90-5681-386-4

(c) Wendy Hansen, Hoeselt 2012

All rights reserved. No part of this thesis may be reproduced, stored in a retrieval system or transmitted in any form or by any means, electronic or mechanical, including photocopy, without prior written permission of the publisher and copyright owner, or where appropriate, the publisher of the articles.

Cover design: Wendy Hansen, Océ Business Services

Printed by: Océ Business Services, Maastricht 


\title{
Bacterial and fungal infections: evolving towards molecular pathogen diagnostics
}

\author{
PROEFSCHRIFT
}

Ter verkrijging van de graad van doctor aan de Universiteit Maastricht, op gezag van de Rector Magnificus Prof. mr. G.P.M.F. Mols, volgens het besluit van het College van Decanen,

in het openbaar te verdedigen op 20 juni 2012 om 10.00 uur

door

Wendy Lucie Jan Hansen

geboren te Bilzen op 17 september 1984 


\section{Promotor}

Prof. dr. C.A. Bruggeman

\section{Copromotor}

Dr. ir. P.F.G. Wolffs

\section{Beoordelingscommissie}

Prof. dr. M.P. van Dieijen-Visser (voorzitter)

Prof. dr. G. leven (Universitair Ziekenhuis Antwerpen, België)

Prof. dr. ir. A.M. Schols

Dr. A. Vreugdenhil 
Aan mijn ouders 



\section{CONTENTS}

List of abbreviations 9

Chapter 1 General introduction \& outline of the thesis 11

Chapter 2a Evaluation of new preanalysis sample treatment tools 43 and DNA isolation protocols to improve bacterial pathogen detection in whole blood

Chapter 2b Pathogen diagnostics for bloodstream infections: 53 bacterial load issues

Chapter 3a Molecular probes for the diagnosis of clinically relevant 59 bacterial infections in blood cultures

Chapter 3b Rapid identification of Candida species in blood 75 cultures by multiprobe TaqMan PCR assay

Chapter 4 A real-time PCR-based semi-quantitative breakpoint 85 to aid in molecular identification of urinary tract infections

Chapter 5 Rapid identification and genotypic antibiotic resistance 101 determination of staphylococci

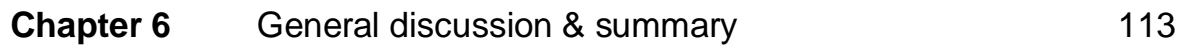

$\begin{array}{ll}\text { Samenvatting } & 125\end{array}$

$\begin{array}{ll}\text { Dankwoord } & 133\end{array}$

$\begin{array}{ll}\text { Curriculum vitae } & 140\end{array}$

$\begin{array}{ll}\text { List of publications } & 141\end{array}$ 



\section{List of abbreviations}

$\begin{array}{ll}\text { ACCP } & \text { American college of chest physicians } \\ \text { AST } & \text { antibiotic susceptibility testing } \\ \text { bp } & \text { base pair } \\ \text { BSI } & \text { bloodstream infection } \\ \text { CAP } & \text { community-acquired pneumonia } \\ \text { cfu } & \text { colony-forming unit } \\ \text { CLSI } & \text { clinical and laboratory standards institute } \\ \text { CoNS } & \text { coagulase-negative staphylococci } \\ \text { CSF } & \text { cerebrospinal fluid } \\ \text { Ct } & \text { cycle threshold } \\ \text { EPIC } & \text { European prevalence of infection in intensive care study } \\ \text { FISH } & \text { fluorescence in situ hybridization } \\ \text { FRET } & \text { fluorescence resonance energy transfer } \\ \text { GPC } & \text { Gram-positive cocci } \\ \text { ICU } & \text { intensive care unit } \\ \text { IFI } & \text { invasive fungal infection } \\ \text { LOD } & \text { limit of detection } \\ \text { MALDI-TOF MS } & \text { matrix-assisted laser desorption ionization time-of-flight } \\ \text { MIC } & \text { mass spectrometry } \\ \text { MLS } & \text { minimal inhibitory concentration } \\ \text { MRSA } & \text { macrolide, lincosamide, and streptogramin antibiotics } \\ \text { NAT } & \text { methicillin-resistant Staphylococcus aureus } \\ \text { NPV } & \text { nucleic acid-based technology } \\ \text { PBP } & \text { negative predictive value } \\ \text { PCR } & \text { penicillin-binding protein } \\ \text { PPV } & \text { polymerase chain reaction } \\ \text { ROC } & \text { positive predictive value } \\ \text { SCCM } & \text { receiver operating characteristic } \\ \text { SCOPE } & \text { society of critical care medicine } \\ \text { SIRS } & \text { surveillance and control of pathogens of } \\ \text { epidemiological importance study }\end{array}$





\section{Chapter 1}

\section{General introduction \& outline of the thesis}




\section{Preface}

Infectious diseases are caused by microorganisms such as bacteria, viruses, fungi or parasites. Some of these organisms constitute the "normal flora" or microbiota present and are participating in the metabolism of food products, the protection against pathogenic microorganisms, and the development and stimulation of the immune system. However, some of them can become pathogenic, for instance when introduced in normally sterile environments such as the blood, or in case of suppression of the immune system. Besides these opportunistic pathogens (e.g., Staphylococcus aureus, Escherichia coli, Candida albicans, Acinetobacterspp.), strict pathogens exist that do not belong to the normal flora, and can cause disease (e.g., Mycobacterium tuberculosis, Vibrio cholera, Neisseria gonorrhoeae). Clinical symptoms associated with infectious diseases are mostly not disease-specific or not microorganismspecific and often include general signs such as fever, loss of appetite, fatigue and muscle aches. Therefore, laboratory tests of different body fluid samples (e.g., blood, urine, cerebrospinal fluid (CSF)) are used for the detection and determination of the causative agent. Traditional culture-based methods in the clinical microbiology laboratory are time-consuming, and are associated with a low sensitivity in case of slow-growing or fastidious microorganisms. In addition, the sample volume ${ }^{1-5}$, the time from sampling to incubation ${ }^{6-9}$, and the use of antibiotics or antifungal therapy can decrease the sensitivity of cultures ${ }^{10-13}$. On the other hand, the specificity of cultures can be hampered by the occurrence of false-positives due to contamination ${ }^{14}$. The rapid and accurate diagnosis of the etiologic agent in infectious diseases is essential for the adequate treatment of the patient. In addition, the simultaneous determination of the microorganisms' antimicrobial susceptibility pattern is strongly needed for the guidance towards pathogen-tailored therapy.

The aim of this thesis was to contribute to a more rapid, sensitive and specific diagnosis of bacterial and fungal infections through the development of rapid real-time polymerase chain reaction (PCR)-based assays for the detection and identification of clinically important bacteria and fungi. In the present chapter, an overview will be given about the diagnostic tools, more specifically real-time PCR-based assays in the current clinical microbiology laboratory. Throughout the remainder of the thesis, experiments will be described in which we evaluated, developed and optimized methods for the isolation and purification of bacterial and fungal DNA from whole blood, blood cultures and urine specimens, the detection and identification of clinically relevant bacteria and fungi from blood cultures and urine specimens, and the genotypic determination of antibiotic resistance in staphylococcal blood culture isolates. 


\section{Bloodstream infections}

Bloodstream infections (BSI), characterized by the invasion of microorganisms in the bloodstream, are a major cause of death all over the world. This lifethreatening condition can be subdivided into bacterial and fungal BSI. In BSI, pathogens are disseminated throughout the body, and this is mostly caused by a primary focus of infection after trauma, or in intravascular devices, or in an organ system initially presenting for instance as a urinary tract infection or respiratory infection. In the United States, approximately 750,000 patients develop bacterial or fungal BSI annually, accompanied with a mortality rate ranging from 20 to $70 \%{ }^{15-18}$. In Europe, it is estimated that each year approximately 135,000 patients die due to sepsis-associated complications ${ }^{19}$. A recent report by Engel et al. presented sepsis as the third most common cause of death in Germany ${ }^{20}$. Within The Netherlands, the annual admission of patients suffering from severe sepsis and septic shock is estimated to be 15,500 and 6,000, respectively ${ }^{21}$. The rapid diagnosis and management of BSI is critical to successful treatment. Inadequate antibiotic therapy is associated with higher mortality rates ${ }^{22,23}$, the appearance of antibiotic resistance in intensive-care units (ICUs) ${ }^{24}$, and longer hospitalization lengths of stay ${ }^{25}$.

\subsection{Bacterial bloodstream infections}

The presence of bacteria in the blood, defined as bacteremia, was first recognized by Libman in 1897 . Two children, presenting with bloody diarrhoea were diagnosed of having streptococcal infection ${ }^{26}$. The occurrence of pathogenic bacteria in the bloodstream can cause severe damage to the body by eliciting a systemic inflammatory immune response, called Systemic Inflammatory Response Syndrome (SIRS). The term was introduced in 1992 at the American College of Chest Physicians/Society of Critical Care Medicine (ACCP/SCCM) Consensus Conference and provided a reference for the complex findings that result from a systemic activation of the innate immune response, regardless of cause ${ }^{27}$. SIRS is considered to be present when the following clinical symptoms are present: body temperature higher than $38^{\circ} \mathrm{C}$ or lower than $36^{\circ} \mathrm{C}$, heart rate higher than 90 beats/min, hyperventilation evidenced by respiratory rate higher than 20 breaths $/$ min or $\mathrm{PaCO}_{2}$ lower than $32 \mathrm{mmHg}$ or white blood cell (WBC) count higher than $12000 \mathrm{cells} / \mathrm{mm}^{3}$ or lower than $4000 / \mathrm{mm}^{327}$. The diagnosis of SIRS in combination with proven infection is called sepsis. Severe sepsis is defined as sepsis with organ dysfunction, hypoperfusion or hypotension. Septic shock is the final stage, in which severe sepsis is associated with hypotension despite adequate fluid resuscitation. Risk factors for the development of BSI include age, underlying diseases, invasive procedures and immunosuppression ${ }^{28}$. Furthermore, the outcome of 
bacteremia can be dependent on the source and the type of microorganism present in the blood. A nationwide surveillance study (Surveillance and Control of Pathogens of Epidemiologic Importance, SCOPE) in US hospitals found 65\% of Gram-positive and $25 \%$ of Gram-negative bacteria as etiologic agent of nosocomial $\mathrm{BSI}^{29,30}$. Coagulase-negative Staphyloccus spp. (CoNS), S. aureus and enterococci were the most common isolated pathogens ${ }^{29}$. Both, the recognition of clinical signs as well as the detection of the causative agent are extremely important in the acute phase of BSI. Hence, a timely and adequate treatment for patients with severe sepsis or septic shock will have a positive impact on outcome $\mathrm{e}^{25,31,32}$. It was shown that the administration of inadequate empirical antimicrobial therapy in septic patients was associated with a higher mortality rate, and also with a longer hospitalization length of stay ${ }^{23,33}$. In this perspective, current culture-based methods do not fulfil the wishes of the clinic since at least 24 to 72 hours are needed for the confirmation of an infectious etiology, the identification of the pathogen, and determination of its antimicrobial resistance profile ${ }^{34}$. Numerous attempts have been made for the improvement of diagnosis of BSI and continue to be developed and evaluated ${ }^{34}$. Though, until now there is not one alternative diagnostic tool capable of totally replacing the blood culture-based approach.

\subsection{Fungal bloodstream infections}

Invasive fungal infections have become a major contributor to ICU-associated infections. One outcome measure of the European Prevalence of Infection in Intensive Care (EPIC) study focused on the most frequently observed microorganism, and revealed the prevalence of fungi in 17\% of ICU infections ${ }^{35}$. Similar reports on nosocomial infections in ICUs were performed in the US, and found fungi as causative agent in 9.5 up to $12 \%$ of the bloodstream isolates ${ }^{29,36}$. The most important risk factors include immunosuppression, use of broadspectrum antibiotics, central venous catheters and recent major surgery ${ }^{37}$. The vast majority of nosocomial fungal infections are caused by Candida spp., and are associated with a high mortality and morbidity ${ }^{38,39}$. Data originated from the 2004 Surveillance and Control of Pathogens of Epidemiological Importance (SCOPE) study defined Candida spp. as the fourth most common cause of all hospital-acquired BSI in the US, and the third most common cause of hospitalacquired $\mathrm{BSI}$ in the $\mathrm{ICU}^{40}$. The most occurring causative species include $C$. albicans, Candida glabrata, Candida parapsilosis, Candida tropicalis and Candida kruse ${ }^{41}$. The prevalence of these opportunistic pathogens, particularly in this group of critically ill patients, emphasizes the importance of an early and accurate diagnosis. Moreover, the empirical treatment is associated with an increased risk for drug toxicity and antifungal resistance. The diagnostic sensitivity of culture-based and histological techniques is often not sufficient 
because some fungi are difficult to culture, and are rarely recovered from clinical specimens. This lack of sensitivity has been shown in patients with chronic disseminated candidiasis and invasive aspergillosis, in which less than $50 \%$ of the blood cultures were positive ${ }^{42}$. Besides, culturing is time-consuming and can take up to three weeks ${ }^{43}$. Many efforts have been made to defeat these shortcomings and alternative methods based on the detection of fungal antigens and pathogen-specific gene signatures are currently reported as most promising molecular diagnostics tools ${ }^{44-48}$.

\section{Blood cultures: the gold standard}

Blood cultures are the "gold standard" of BSI diagnosis and are based on the detection of viable microorganisms in the blood. Whenever microbial growth has occurred, the positive blood culture is used for Gram staining, culture on agar plates, biochemical testing and antibiotic susceptibility testing (AST). The accurate identification of the causative pathogen and the determination of the microorganisms' antimicrobial profile are essential in the management of BSI, since both parameters are of significant importance for the guidance of antibiotic therapy. Therefore, both aspects can be seen as the strength of the current gold standard, because until now no other technique can offer both diagnostics parameters. Blood cultures have a central role in the clinical microbiology laboratory. In the past, numerous studies have been conducted to define the factors influencing the sensitivity of the procedure as well as to establish the most optimal conditions for blood culture processing. The current Clinical and Laboratory Standards (CLSI) guidelines provide the general principles and procedures for blood cultures from patients who are suspected of having bacteremia or fungemia ${ }^{4}$. The continuous optimization of various technical elements in blood culture processing such as automated detection of growth, or enhancement of culture media has lead to major improvements of the diagnostic performance. Though, several factors exist limiting the medical value of blood cultures.

\section{Diagnostic yield}

One of the most determining factors in the detection of pathogens is the blood volume $^{1,2}$. Studies of adult patients have reported numbers between 1 and 100 colony-forming units per millilitre (cfu/ml) during bacteremic episodes ${ }^{49-51}$. Pediatric patients are thought to have higher numbers of bacteria in the blood ${ }^{49}$, however, reports also showed the occurrence of low-level bacteremia $(\leq 10$ cfu/ml) in $60-70 \%$ of their population ${ }^{52}$. The diagnostic yield is directly related to the volume of blood sampled, as presented in several studies of both adult ${ }^{3,53,54}$ and pediatric patients ${ }^{55,56}$. As recommended in the CLSI guidelines, 20 to $30 \mathrm{ml}$ 
of blood per culture set should be drawn in adults ${ }^{4,51}$. This can be particularly problematic for pediatric patients, for whom mostly inadequate sample volumes can be obtained.

\section{Non-cultivable pathogens and antimicrobial therapy}

A second limitation of blood cultures is the lower sensitivity for slow-growing and fastidious microorganisms. These include pathogens involved in systemic diseases such as Whipple's disease (Tropheryma whipplei), bartonellosis (Bartonella spp.), Q fever (Coxiella burnetii) and rickettsiosis (Rickettsia spp.) ${ }^{57,}$ ${ }^{58}$. Many of these microorganisms can also be found in blood culture-negative infective endocarditis ${ }^{59}$. Furthermore, pathogens causing community-acquired pneumonia (Legionella pneumophila, Chlamydia pneumonia, and Mycoplasma pneumonia) can render negative blood cultures ${ }^{60}$. The occurrence of these fastidious and slow-growing pathogens will cause a serious delay in the identification process, which can lead to prolonged and inadequate empirical antimicrobial therapy. Another potential interfering factor resulting in negative blood cultures is previous antimicrobial therapy, which can give rise to falsenegative results ${ }^{10,11,13}$. This can be particularly the case in patients receiving prophylactic antibiotics. In these cases, the inhibitory effect of antibiotics must be prohibited by using the most optimal culture conditions.

\section{$\underline{\text { Turnaround time }}$}

A third reason limiting the clinical value of blood culture is the delay in time to results. After the detection of microbial growth in a blood culture bottle, Gram staining is performed and the positive blood culture is used for further culturing on plate. The median time to positivity is approximately 15 hours (range 2.6-127 hours) ${ }^{61-63}$, and subsequent subculturing takes an additional time of at least 24 hours. Of course, the bacterial or fungal load, the type and characteristics of the pathogen are factors influencing these time ranges. Rapid Gram staining and biochemical tests can offer an initial insight about the etiologic agent within one hour after growth detection. However, more time is needed for the final identification and AST of the causative agent.

\section{Molecular pathogen diagnostics}

Molecular techniques have become a growing field of interest for the detection and identification of bacteria and fungi present in bloodstream infections. This is mainly due to the limitations associated with the conventional culture-based approach which include the delay between sampling and analysis, the need for bacteriological expertise, the personnel workload and the insensitivity for 
fastidious or slow-growing microorganisms. Major evolutions have been made so far, but even today, the ideal technique, in which simultaneous pathogen identification and determination of the antimicrobial susceptibility pattern is provided, does not exist. Throughout the years, many technologies were evaluated and an overview of the different approaches is given in Figure 1. The diagnosis of bacterial or fungal BSI can be based on the detection of pathogens from cultured specimens (blood culture) or directly from whole blood, plasma or serum. The latter category demands a higher performance capacity in terms of detection limit because of the potential low number of microorganisms in the blood. The identification of the etiologic agent without the need for prior culturing would reduce the turnaround time drastically, and would enable quantification of the bacterial or fungal load. The next section will highlight existing and more recent technologies for the detection and identification of pathogens that are based on the detection of nucleic acids (real-time PCR, fluorescence in situ hybridization (FISH)) or proteins (matrix-assisted laser desorption ionization time-of-flight mass spectrometry (MALDI-TOF MS)). These molecular assays may offer several advantages such as rapidity (i.e. within a few hours), require small sample volumes, enable high-throughput, and reduce microbiological workload.

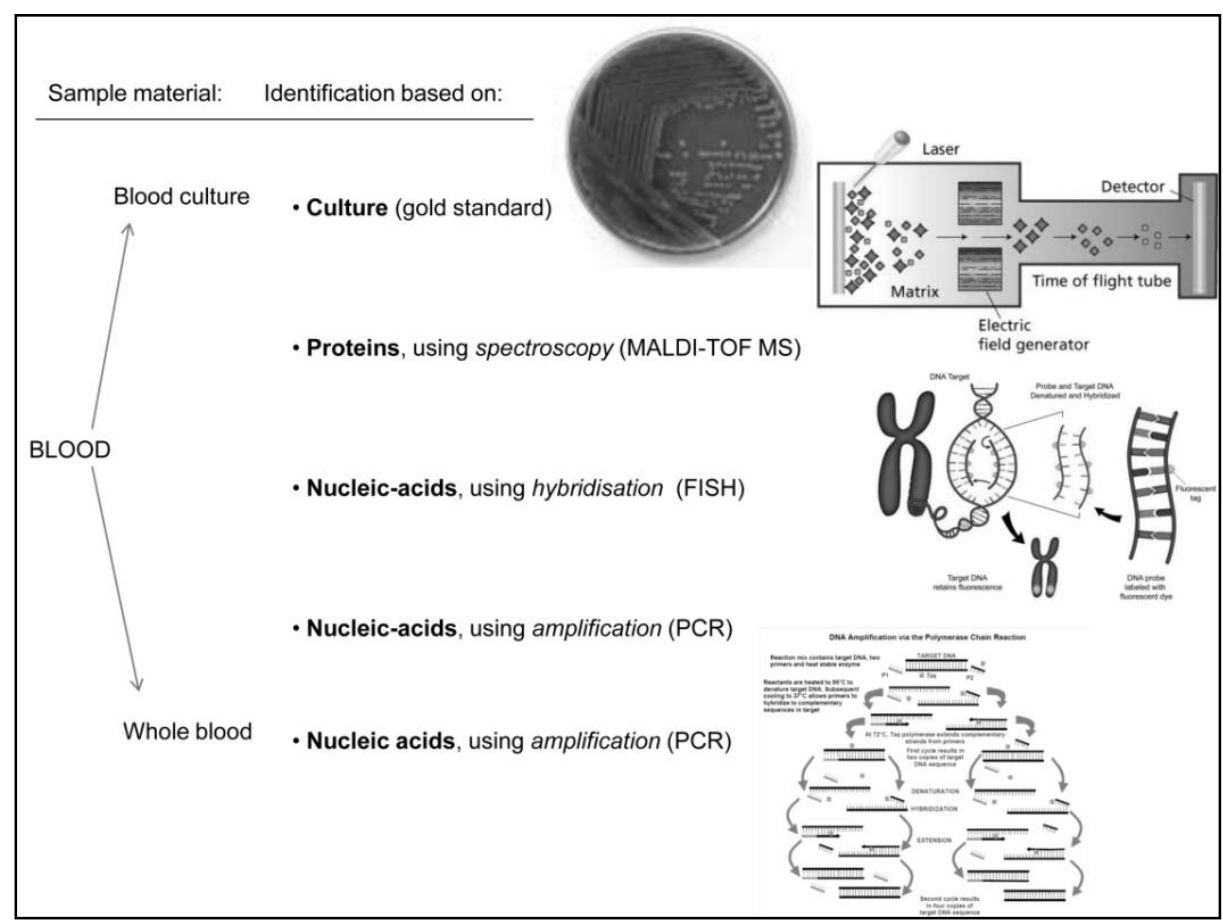

Figure 1. Overview of the most frequently used techniques for the detection and identification of bacterial and fungal pathogens involved in bloodstream infections. This figure was redrawn from Peters, $2004^{64}$. 


\section{Protein-based identification techniques}

Protein-based identification uses vibrational spectroscopy for the determination of the protein composition of a sample, and a widely discussed application is matrix-assisted laser desorption ionization time-of-flight mass spectrometry (MALDI-TOF MS). In clinical microbiology, MALDI-TOF MS is used to analyze specific peptides or proteins which are directly desorbed from microorganisms ${ }^{65}$. The taxonomic classification of individual microorganisms is based on the existence of unique proteomic fingerprints that allow speciesspecific identification, and was first reported about 30 years ago ${ }^{66}$. Previous studies showed that MALDI-TOF MS can be used for the identification of Grampositive bacteria ${ }^{67-72}$, Enterobacteriaceae ${ }^{73}$, non-fermenting bacteria ${ }^{74-77}$, mycobacteria $^{78-80}$, anaerobes ${ }^{71,81}$, and yeasts ${ }^{82,83}$.

MALDI-TOF MS allows a very rapid, i.e. within minutes, identification of the microorganism, but currently involves a prior culturing step to increase the number of microbial cells for analysis. Recent studies investigated the potential use of positive blood cultures as starting material for MALDI-TOF MS ${ }^{84-89}$. Whereas bacterial identification from colonies can be performed without any sample preparation, pre-treatments are suggested in case of fungal identification. Using blood cultures as specimen obligates the need of eliminating human red blood cells in order to prevent interference during MS analysis. As suggested by Drancourt et al. the most optimal protocol for processing of blood cultures remains to be developed and evaluated to enable standardisation and automation ${ }^{90}$. The main problems encountered with MALDITOF MS analysis are the difficulty in identifying mixed organisms ${ }^{86,87,89}$ and viridans Streptococcus spp. organisms ${ }^{86,87}$. Although suggested as a candidate method replacing traditional techniques for microbial identification ${ }^{91}$, one has to keep in mind that successful MALDI-TOF MS analysis is dependent on the microbial load $\left(10^{7}-10^{8} \mathrm{cfu} / \mathrm{ml}\right)$ requiring pre-culturing of the blood. Apart from the identification process, the role of MALDI-TOF MS in the determination of antibiotic resistance needs further investigation. First reports presented the successful identification and discrimination of methicillin-resistant $S$. aureus $(\mathrm{MRSA})^{92,93}$. However, the search for other antibiotic resistance determinants remains to be elucidated.

\section{Nucleic acid-based identification techniques}

Nucleic acid-based technologies (NATs) have been introduced for the rapid identification of microorganisms and are based on the detection of microorganism-specific DNA or RNA sequences. Widely studied NATs that have been used for the diagnosis of infectious diseases include detection assays based on hybridization or amplification of target sequences. An example 
of a hybridization-based assay is fluorescent in situ hybridization (FISH), in which fluorochrome-labelled oligonucleotide probes targeted to rRNA are visualised using microscopy. In previous studies, FISH assays were developed for the detection of Chlamydia spp. ${ }^{94}$, Enterococcus spp. ${ }^{95}$, Pseudomonas aeruginosa ${ }^{96}$, Helicobacter spp. ${ }^{97}$, Streptococcus spp. ${ }^{98}$, Staphylococcus spp., Escherichia coli ${ }^{96}$, Candida spp., and other Enterobacteriaceae ${ }^{95,}{ }^{99}$. FISH allows the identification of bacteria and yeast from blood cultures within 2 to 5 hours. The usefulness of the procedure is largely dependent on the type of microorganism since the permeabilization of the cell wall during sample preparation is a critical step in the process. Next, the technology is highly specific, but depending on probe design and hybridization conditions. Because of the currently limited probe repertoire, species-specific identification is not possible for all bacterial species. In a study of Peters et al. identification at genus or family level and at species level was shown in $91 \%$ and $79 \%$, respectively ${ }^{100}$. These results confirmed earlier data obtained by Kempf et al. in which the usefulness of $\mathrm{FISH}$ as a diagnostic test was recommended ${ }^{99}$. Though, the panel of probes included should be well considered and designed in relation to the pathogens present in a specific patient setting. Among the amplification-based NAT, the polymerase chain reaction (PCR) and its derivatives are one of the preferred methods. This branch of molecular techniques will be discussed in the next paragraphs. First, the importance of sample preparation will be discussed, followed by the opportunities associated with real-time PCR assays.

\section{Nucleic acid extraction}

In order to release and concentrate microbial DNA, the extraction and purification of bacterial and/or fungal nucleic acids from patient specimens involves a three-step procedure including the lysis of the microorganism, followed by the selective binding and elution of the bacterial and/or fungal DNA. Independent of the downstream NAT application, the purification of the bacterial or fungal nucleic acids from the sample material is a critical step in the whole process $^{101}$. The low concentration of pathogenic DNA in relation to the high amount of human DNA ${ }^{102}$, the presence of PCR-inhibitory compounds in patient specimens and/or culture media ${ }^{103,}{ }^{104}$, and the possible presence of contaminating bacterial or fungal DNA in reagents ${ }^{105-108}$ are important challenges that are faced during the diagnosis of bacterial and fungal pathogens. Classical phenol/chloroform extraction followed by ethanol precipitation is toxic, and impractical for the processing of large numbers of samples. During recent years, many commercial kits and automated DNA isolation instruments were developed and evaluated, and mainly use spin- 
column-based extraction (e.g., QIAamp DNA Mini Kit (Qiagen, Hilden, Germany)).

The popularity of the latter is mostly based on the low costs and the easiness to use, only requiring standard equipment which is available in most routine laboratories. The principle of DNA extraction using column purification is i) release of the nucleic acids through denaturation of the proteins with chaotropic salts, ii) separation of the nucleic acids through adsorption onto a silica gel membrane, iii) washing with high-salt-concentration buffers to remove denatured proteins and other compounds, iv) elution of the bound DNA with a low-salt-concentration buffer. In a study by Rantakokko - Jalava and Jalava, the results indicated that no single DNA extraction method is optimal for the detection of all microorganisms, and for application to every patient specimen ${ }^{109}$. Indeed, for the extraction of fungal nucleic acids, it became clear that specific protocols need to be used because of the difficulty in breaking the cell wall ${ }^{43,110}$. Therefore, as more insights were gained concerning the different types of patient specimens and the subsequent variable presence of inhibitory compounds, methods were fine-tuned according to the application.

\section{Detection in direct patient specimens (without enrichment)}

In order to facilitate a rapid detection of the causative infectious agent, processing of patient specimens without prior bacterial/fungal enrichment, i.e. direct specimens are preferred. Nucleic acid extraction from direct patient specimens such as whole blood, plasma or serum can be difficult because of the high amount of human DNA versus the low amount of bacterial DNA. In addition, whole blood contains many PCR inhibiting substances which emphasize the need for further processing ${ }^{111}$. Commercially available DNA extraction kits were evaluated and compared in terms of performance between with or without proteinase $\mathrm{K}$ digestion ${ }^{112}$, manual or automated nucleic acid extraction ${ }^{113}$, binding-plate or filter-plate format or magnetic bead format ${ }^{114}$. More recently, commercial whole blood assays such as MolYsis (Molzym, Bremen, Germany), Looxster (SIRS-Lab, Jena, Germany) and Septifast (Roche Diagnostics, Mannheim, Germany) DNA isolation Kit were developed and included a pre-treatment protocol together with a DNA extraction protocol. The focus of these kits is the removal of interfering host DNA and the enrichment of pathogen DNA. In a study performed by Handschur et al., results showed that the removal of human DNA eliminated unspecific signals occurring in the $16 \mathrm{~S}$ rDNA real-time $\mathrm{PCR}^{115}$. Wiesinger - Mayr et al. compared different commercially available assays (Looxster, MolYsis Kit, SeptiFast, standard EasyMAG (BioMérieux, Marcy l'Etoile, France) DNA isolation) with a semiautomated EasyMAG protocol, supplemented with pre-processing steps involved in human DNA elimination ${ }^{116}$. Together with the Looxster kit, the 
modified EasyMAG protocol generated the most sensitive results, achieving a detection limit of $10^{1}$ to $10^{2}$ bacterial cells per $\mathrm{ml}$ of whole blood. Besides whole blood, reports also showed the applicability of these tests to oral samples such as saliva ${ }^{117,118}$, and other clinical samples such as tissue biopsy, synovial fluid, pleural fluid, and CSF specimens ${ }^{109}$. The addition of pre-processing steps (i.e. human DNA elimination with MolYsis or Looxster) removed at least $90 \%$ of the human DNA present in oral samples, whereas bacterial DNA recovery ranged between 35 and $50 \%{ }^{117,}{ }^{118}$. The data presented by Rantakokko - Jalava and Jalava indicated that no single method is optimal for the detection of all bacteria, or for all patient specimens ${ }^{109}$.

\section{Detection in cultured patient specimens}

Cultured patient specimens such as blood cultures consist of a high bacterial or fungal load, but inhibitory substances such as the anticoagulant and anticomplementary agent sodium polyanethol sulfonate (SPS) can influence downstream applications like PCR ${ }^{119}$. Millar et al. compared a series of commercially available (Qiagen QIAmp Blood kit (Qiagen, Hilden, Germany), Roche high PCR template preparation kit (Roche Diagnostics, Mannheim, Germany), Puregene DNA extraction kit (Qiagen, Hilden, Germany)) and inhouse assays (boiling, glass beads/sonication and wash/alkali/heat lysis) for blood cultures, and presented a wash/alkali/heat lysis method as the most sensitive, reproducible and cost-effective DNA extraction method ${ }^{120}$. Besides the high yield of bacteria and/or fungi present in positive blood cultures, a more rapid identification and antibiotic susceptibility pattern of life-threatening pathogens such as MRSA ${ }^{121-123}$ and Streptococcus pneumonia ${ }^{124,125}$ can be achieved. More recently, a study was performed in which six DNA extraction protocols were compared to accelerate the detection of $S$. aureus and coagulase-negative staphylococci (CoNS) from two different types of blood culture materials, i.e. BACTEC (Becton, Dickinson and Company, Sparks, US) and BacT/ALERT (BioMérieux, Marcy l'Etoile, France) ${ }^{126}$. The most sensitive technique achieved a detection limit of $10 \mathrm{cfu} / \mathrm{ml}$ in BacT/ALERT material, whereas $100 \mathrm{cfu} / \mathrm{ml}$ could be detected in BACTEC blood culture material. In addition, they tested the effect of reduced blood culture incubation times in combination with the most sensitive extraction method, and showed that an initial S. aureus or CoNS load of $1 \mathrm{cfu} / \mathrm{ml}$ could be detected after five hours of incubation, compared to 28 hours with conventional methods. These results were also shown in a paper presented by Gebert et al. ${ }^{127}$ and revealed a significant reduction in time to results. This is also of importance for another group of microorganisms, i.e. fungi, which could also benefit from accelerated detection, since full identification can take more than 72 hours ${ }^{128}$. 


\section{Nucleic acid amplification}

The PCR constitutes one the most important nucleic acid amplification techniques and was developed by Mullis and Faloona in $1987^{129}$. PCR is used for the in vitro-amplification of DNA, which functions as a molecular fingerprint ${ }^{130}$. The DNA is copied by a heat-stable polymerase in the presence of nucleotides, buffers and primers (Figure 2).

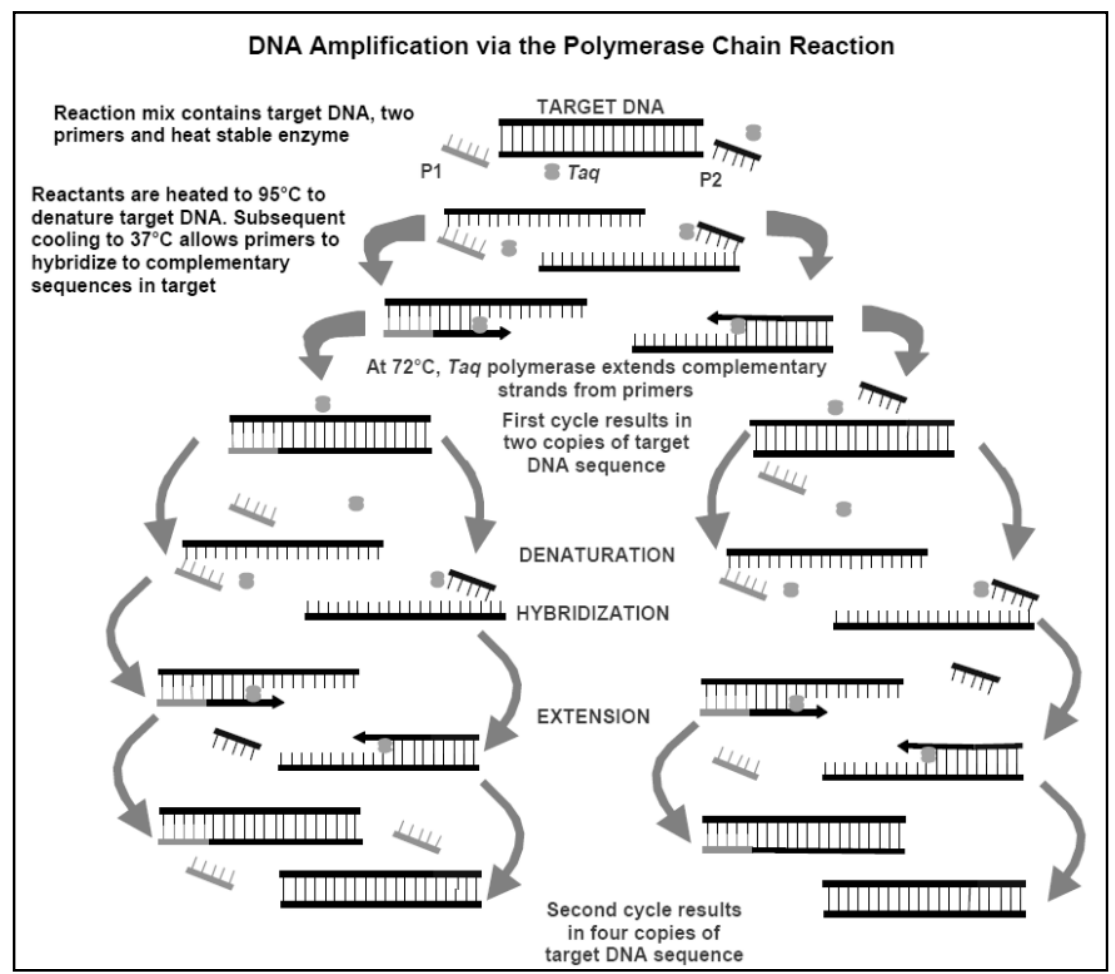

Figure 2. The basic mechanism of the polymerase chain reaction (PCR). This figure was redrawn from ORNL-DWG91M-17476.

Primers are short DNA oligomers that are complementary to the ends of a target sequence. The primers hybridize to their complementary regions of DNA, and subsequently DNA polymerases extend the DNA strands, producing a copy of the DNA. Each copy of DNA serves as another template, resulting in an exponential amplification of the original DNA sequence. In the clinical microbiology laboratory, PCR was introduced as a promising technique for the molecular diagnostics of infectious disease ${ }^{131-133}$. Both unique and eubacterial (e.g., 16S rDNA) DNA sequences of microorganisms can be used for their identification, or can be helpful in the discrimination between certain types of microorganisms. The development of real-time PCR, which combined 
conventional PCR with fluorescent probe detection of the amplified DNA product, offered major opportunities in the field of molecular pathogen diagnostics ${ }^{134-138}$. In real-time PCR, nucleic acid amplification and detection are performed within the same closed vessel, minimizing the risk for contamination. In addition, compared to conventional PCR, the ease of performance, speed and high sensitivity and specificity levels have made real-time PCR an appealing alternative approach for the conventional culture-based diagnosis of infectious diseases.

The most traditional method for the visualization of double-stranded DNA product is SYBR Green nucleic acid detection. SYBR Green assays are not specific, but can provide melting curve analysis for the determination of the melting temperature of the different amplification products. Instead, the use of fluorescent probes, capable of fluorescence resonance energy transfer $(\mathrm{FRET})^{139}$, allowed sensitive and specific detection of target DNA. The first fluorescent probes were TaqMan probes, or also called 5' nuclease probes, which are short oligonucleotides containing a 5' fluorescent dye and 3' quenching dye. The fluorescent and quenching dye have to be separated by the Taq polymerase in order to generate a light signal. This can only be achieved when the probe binds to a complementary strand of DNA, which underlines the specificity of this technology. The accumulation of amplification product can be monitored in real time and generates a change in signal, which can be related to the amount of DNA present during each cycle ${ }^{135}$. Other types of nucleic acid detection using fluorescent probes are molecular beacons and FRET hybridization probes $^{140}$.

\subsection{Identification of bacteria and fungi}

The high sensitivity and specificity together with a short turnaround time for results, and the ease of performance make real-time PCR a promising replacement method for conventional culture-based identification methods ${ }^{140}$. Numerous studies describe real-time PCR-based assays for the identification of bacteria and fungi, and they can be based on broad-range, pathogen-specific or multiplex detection. Pathogen-specific assays are targeted to a single bacterium of fungus, and have a more limited role in diagnostic settings because of the high variety of pathogenic microorganisms responsible for infectious diseases ${ }^{34}$. However, in some diseases such as typhoid fever, the rapid identification of Salmonella typhi was established using species-specific real-time PCR detection ${ }^{141,142}$. Also, in previous studies pathogen-specific assays were developed for the detection of Staphylococcus epidermidis ${ }^{143}, S$. aureus ${ }^{144,145}$, MRSA $^{121-123,} 1^{146-149}$, S. pneumonia ${ }^{150-153}$, Neisseria meningitides ${ }^{154,} 155, M$. tuberculosis ${ }^{156-158}$, Brucella spp., C. albicans ${ }^{159}$, and Aspergillus spp. ${ }^{160}$. The main disadvantage is that they only can be used when a certain pathogen is 
suspected, and laboratory confirmation is needed. In the diagnostic workup of patients with fever and suspected bloodstream infection broad-range detection or multiplex assays are preferred ${ }^{128}$. Universal targets such as the 16S rDNA gene or the 16S-23S rDNA gene interspacer region for bacteria ${ }^{161-163}$, or the $18 S$ and 28S rDNA gene for fungi ${ }^{164,}{ }^{165}$ are being used extensively for identification ${ }^{166}$. For instance, the $16 \mathrm{~S}$ rDNA gene sequence is about 1550 base pairs (bp) long, composed of both variable and conserved regions, demanding the need for post-amplification sequencing ${ }^{167}$. Sequencing facilitates the identification of the etiologic agent, but no differentiation at the species or strain level is possible with this technique. Broad-range PCR in combination with sequencing has been applied to identify bacteria from blood ${ }^{168-178}$, but this is laborious, rather expensive and time-consuming ${ }^{128}$. A review of Clarridge focused on the impact of $16 \mathrm{~S}$ rDNA gene sequence analysis in clinical microbiology. They described both the opportunities and limits associated with this technology ${ }^{167}$. More recently, in a review of Sontakke et al. the past and current applications of broad-range 16S rDNA PCR for the diagnosis of bacterial infections are summarized and discussed ${ }^{179}$. A compromise between pathogen-specific and broad-range detection could be achieved with the development of multiplex PCR assays. Multiplex real-time PCR detection assays use one or more primer sets, eventually in combination with one or more fluorogenic oligoprobes for the amplification of multiple targets within a single reaction. Different strategies can be used, and one of them comprises the use of different primer sets that are specific for one microorganism ${ }^{180-182}$. On the other hand, one broad-range primer set can be used in combination with different fluorescently labelled probes complementary for a panel of bacterial and/or fungal targets. Some studies reported the use of molecular probes for the classification of Gram-type ${ }^{184}$, eventually in combination with pathogen identification ${ }^{127,183,184}$, and achieved detection within three to six hours, while sensitivity and specificity ranged between $95 \%$ and $100 \%$ compared with the conventional culture-based method. Nowadays, many commercial systems offering a panel of clinically relevant bacteria and/or fungi have been developed and evaluated. One of the most described commercial assays available for the identification of bacteria and fungi is the SeptiFast (Roche Diagnostics, Mannheim, Germany) test. The kit is intended for the identification of up to 25 microorganisms from whole blood using real-time PCR coupled to melting curve analysis ${ }^{185}$. The latest studies, both in adults ${ }^{186-189}$ and children ${ }^{190}$ demonstrated the potential of SeptiFast to be of added value to blood cultures, by reducing the time to results and adding diagnostic yield, especially in antibiotic pretreated patients. Other similar testing platforms are Prove-It Sepsis (Mobidiag, Helsinki, Finland), which combines broad-range PCR with microarray hybridization for the detection of 60 bacteria and 13 fungi from blood cultures. Gaibani et al. found an agreement of more than $90 \%$ (when the microorganisms 
found in blood culture were included in the Prove-It Sepsis panel) between Prove-It Sepsis and blood cultures ${ }^{191}$. The SepsiTest (Molzym GmbH, Bremen, Germany) consists of a broad-range real-time PCR (absence of presence of microorganisms) combined with sequence identification, capable of detecting more than 345 bacteria and fungi from whole blood specimens. In a study performed by Wellinghausen et al. results showed that the concordance of PCR and blood culture for positive and negative samples was $86 \%{ }^{192}$. The VYOO Kit (SIRS-Lab GmbH, Jena, Germany) uses a multiplex PCR followed by microarray analysis, enabling the detection of 34 bacteria and seven fungi from whole blood samples. Yet, no published data on clinical experience exist, only two abstracts were reported on 24 (Sachse, unpublished data) and 63 (Bloos, unpublished data) patients ${ }^{193}$. Application of VYOO did only result in $15 \%$ of modifications of antimicrobial therapy and positive PCR was not associated with increased mortality ${ }^{193}$. Overall, the turnaround times of the described commercial assays ranged between 3.5 hours to 7 hours, except for the SepsiTest, which involves sequence identification. Although the presented data showed the potential of newly developed molecular assays based on real-time PCR in terms of rapid pathogen identification, interventions studies are needed that focus on clinical experience, i.e. patient outcome and modification of antimicrobial or antifungal therapy.

\section{Determination of the bacterial load}

In clinical microbiology, real-time PCR assays are mainly used for the qualitative (i.e. absence or presence) detection and identification of microorganisms. However, the quantification of bacterial and/or fungal pathogens from direct specimens such as whole blood could enable correlation with important clinical parameters such as disease severity, therapy response, and outcome. Few studies have been performed to prove correlation between bacterial or fungal DNA load and disease severity. In a study focusing on patients with meningitis, meningococcal bacterial DNA load was found to be significantly higher in patients with severe compared to milder disease ${ }^{194}$. Also, bacterial DNA load was shown to be a diagnostic marker of pneumococcal infection in patients with community-acquired pneumonia $(\mathrm{CAP})^{195}$, and this was in concordance with another report by Kee et al. ${ }^{196}$. In certain diseases (e.g., urinary tract infections (UTIs), endocarditis) quantification of pathogens is essential because the diagnosis is based on clinical symptoms together with the bacterial load of the etiologic agent. For instance, the diagnosis of UTIs is based on semi-quantitative urine culture (reference standard) since different bacterial loads $\left(>10^{3}\right.$ or $\left.10^{5} \mathrm{cfu} / \mathrm{ml}\right)$ are used to identify UTIs in different patient populations $^{197}$. Also, discrimination may be possible between the presence of contaminants and causative pathogens. This can be relevant in samples in 
which distinction is needed between normal flora and disease-causing microorganisms, such as in patients with corneal ulcer, as studied in a paper of Itahashi et $a^{198}$. Quantification of pathogens has also been investigated in other patient specimens such as blood ${ }^{195,199}$ and CSF $^{200,201}$. One of the drawbacks described in these reports is the lack in distinction between viable and dead microbial cells. Following, the origin of the bacterial DNA is unclear, and may cause difficulties in interpretation when patients receiving antibiotics are monitored in time. After the administration of antibiotics, the amount of living bacteria is reduced, while bacterial DNA may persist ${ }^{194,}{ }^{202,} 203$. Therefore, the clinical value of bacterial load determination (i.e. bacterial DNA) remains to be elucidated in terms of correlation with disease severity, patient outcome, and therapy response.

\subsection{Detection of antibiotic resistance genes}

Besides detection and identification of microorganisms, antimicrobial susceptibility testing (AST) of bacterial pathogens is one of the main functions of the clinical microbiology laboratory, and is essential for the guidance of antimicrobial therapy. Reports have shown that the administration of the appropriate antibiotics is correlated with a decrease in mortality ${ }^{25}, 32,33,204$. Conventional AST methods including agar dilution, broth microdilution, E-test and disk diffusion, still involve pure subculturing and therefore take up to 24 hours before initial results are known. To increase the rapidity and accuracy of susceptibility testing, genotypic methods have been introduced for the detection of antibiotic resistance genes ${ }^{205-207}$.

\section{Staphylococci}

Throughout the years, many studies have focused on the genotypic detection of antibiotic resistance using in real-time amplification of known resistance genes, of which $m e c A$, the gene for methicillin (oxacillin) resistance in staphylococci is most established in clinical practice ${ }^{121,208-214}$. Methicillin resistance in staphylococci is conferred by the chromosomally located mecA gene, which encodes for an altered penicillin-binding protein PBP2a ${ }^{215-217}$. Production of PBP2a results in a lowered affinity for beta-lactam antibiotics. Both $S$. aureus and CoNS are known to accumulate more than one antibiotic resistance determinant, resulting in multi-drug resistant strains. Therefore, other antibiotics including penicillins, aminoglycosides, glycopeptides and macrolide, lincosamide, and streptogramin (MLS) antibiotics are also commonly used to treat infections caused by staphylococci, and are of particular interest for further implementation in a rapid real-time PCR assay. Resistance to penicillins is caused by the presence of the bla $z$ gene, which encodes for beta-lactamase, an 
enzyme responsible for the hydrolysis of the beta-lactam nucleus ${ }^{218}$. Vancomycin, belonging to the group of the glycopeptides, is used to treat infections caused by multi-resistant Gram-positive microorganisms such as oxacillin-resistant staphylococci. VanA-type resistance is the most commonly encountered form and results in the production of an alternative D-ala-D-ala ligase, a cell wall precursor with a lowered affinity to glycopeptides ${ }^{219}, 220$. Resistance to aminoglycosides occurs mainly because of the presence of aminoglycoside-modifying enzymes that interfere with protein synthesis. The most encountered one is 6'- $\mathrm{N}$-acetyltransferase-2"-O-phosphotransferase (AAC(6')-APH(2"), and is encoded by the aac(6')-aph(2") gene $e^{220}$. The presence of this gene results in phenotypic resistance to gentamicin, kanamycin, tobramycin, neomycin and amikacin ${ }^{221}$. Within the group of the MLS antibiotics different mechanisms of acquired resistance have been found in Gram-positive bacteria ${ }^{220}$. Target modification by methylases, which are encoded by erythromycin ribosome methylation (erm) genes, is the most common mechanism found. Another relevant possibility is the presence of efflux proteins, encoded by for instance the $m s r A$ gene. Presence of the msrA gene confers resistance to both macrolides and streptogramin B antibiotics (MS phenotype) $)^{220,222}$

DNA microarray-based detection of antibiotic resistance genes can be used as a tool for the determination of a detailed antimicrobial resistance profile, as was presented by Perreten et al. ${ }^{223}$. They reported a DNA microarray capable of detecting 90 antibiotic resistance genes occurring in Gram-positive bacteria. A similar report by Frye et al. also presented a DNA microarray including 94 antimicrobial resistance genes in both Gram-positive and Gram-negative bacteria $^{224}$. Although the presented microarrays have been shown to be efficient prototypes for the rapid screening of antibiotic resistance genes, the high costs associated with this technique limit the clinical applicability. From this perspective, small-scale microarrays have been developed, offering the detection of a panel of clinically relevant staphylococcal antibiotic resistance genes $^{225,226}$. Zhu et al. found correlations were more than $90 \%$ for detection of the phenotypic resistance in 415 staphylococcal isolates, while Strommenger et al. only tested 13 clinical isolates as a proof of concept, resulting in $100 \%$ concordance with phenotypic AST. Besides DNA microarrays, multiplex realtime PCR assays have been designed offering a similar panel of antibiotic resistance genes (e.g., mecA/methicillin resistance, aacA-aphD/aminoglycoside resistance, ermA-B-C-msrA/MLS resistance, vatA-B-C/streptogramin A resistance, blaz/penicillin, vanA/vancomycin) ${ }^{227-231}$. Overall, high correlations were found between genotypic and phenotypic analysis, though it has to be taken into account that novel or unknown resistance mechanisms may exist, harbouring the analytical sensitivity of the assay. For this reason, current genotypic antibiotic resistance detection assays have to be seen as an additive 
to traditional AST testing, offering a faster detection of certain antibiotic resistances (e.g. methicillin resistance, vancomycin resistance) that are associated with a high clinical relevance.

\section{Hypothesis and Outline of the Thesis}

More than ever, molecular diagnostics is used as platform for the detection and identification of pathogens in the field of infectious diseases. Techniques included in this niche of diagnostic testing are ought to be rapid, sensitive, specific and robust. However, the successful application of molecular techniques is dependent on many factors. A wide variety of sample materials can be processed, although different sample preparations might be required. Analysis of whole blood would be the most favourable approach because of the relevant applicability in for instance urgent interventions at intensive care units (ICUs). Though, the complex mixture of human and bacterial or fungal DNA and other interfering compounds makes it the most challenging sample for designing a suitable handling protocol. Detection and identification of bacterial pathogens can be established using a wide variety of molecular techniques. An assay must be founded on a simple and straightforward technique, in combination with rapid en reproducible results. The main objective of this thesis was to contribute to a more rapid diagnosis of bacterial and fungal infections in whole blood and blood culture samples. To realize this goal, the whole process from sample collection to data interpretation, was carefully unravelled.

First, we evaluated a series of preanalysis sample treatment tools and DNA isolation protocols for whole blood samples. Pre-analytic kits have been developed for the removal of human DNA and the selective enrichment of bacterial DNA. Therefore, we determined the detection limits of four selected DNA extraction kits in combination with two novel pre-analytical sample treatment protocols for the isolation of methicillin-resistant Staphylococcus aureus (MRSA) DNA from whole blood (Chapter 2a).

One of the limiting factors of whole blood can be the presence of low counts of circulating bacteria in the bloodstream. This is also influenced by patient- and infection-related characteristics. The level of implementation of molecular techniques will be dependent on these individual-specific features and will determine the potential of working with whole blood. Hence, we focused on the bacterial load in neonates in order to obtain better insights in the requirements needed for successful application of nucleic acid amplification techniques (Chapter 2b).

Next, we aimed to design a rapid and clinically relevant molecular assay capable of the detection and identification of the most frequently encountered microorganisms causing bloodstream infections. Moreover, priority was given to those pathogens that could direct the choice of antibiotic therapy. The $16 \mathrm{~S}$ 
rDNA gene signature, present in all bacteria, was used for the design of fluorescently labelled probes. Using a real-time PCR-based platform supplemented with four species- and four genus-specific probes, we were able to identify important bacterial pathogens from positive blood cultures within two hours (Chapter 3a).

Earlier data pointed out that besides bacteria certain fungi comprise a significant population found in blood cultures. Invasive fungal infections are particularly considered as cause of opportunistic infections in immunosuppressed patients. So, a rapid diagnosis and therapy is directly connected with patients' outcome. Gram-stained specimens presenting with yeasts were subjected to a real-time PCR assay containing probes for Candida spp., Candida albicans, Candida glabrata, Candida krusei and Candida parapsilosis (Chapter $\mathbf{3 b}$ ).

Both newly developed assays proved to be of relevant value in the diagnosis of bloodstream infections (BSIs). In an attempt to broaden the application field of these methods, we wanted to expand the bacterial pathogen identification assay with a semi-quantitative tool for diagnosis of infections requiring enumeration of the bacteria. Therefore, a semi-quantitative real-time PCRbased breakpoint was established to aid in the diagnosis of urinary tract infections (UTIs) (Chapter 4).

Knowledge about the kind of causative pathogen is coherent to the determination of the antimicrobial resistance profile in order to direct the most suitable antibiotic therapy. In parallel to the identification of staphylococci, the most relevant antibiotic resistance phenotypes were genotypically determined in a real-time PCR assay. The development of such an assay, capable of identification and antibiotic susceptibility testing of the bacterial pathogen, would contribute to a more rapid diagnosis and therapy of BSI (Chapter 5).

In the last chapter (Chapter 6), a summary is made of the preceding findings and future perspectives are given. 


\section{References}

1. Hall MM, Ilstrup DM, Washington JA, 2nd. Effect of volume of blood cultured on detection of bacteremia. J Clin Microbiol 1976; 3: 643-5.

2. Tenney $\mathrm{JH}$, Reller LB, Mirrett $\mathrm{S}$ et al. Controlled evaluation of the volume of blood cultured in detection of bacteremia and fungemia. J Clin Microbiol 1982; 15: 558-61.

3. Cockerill FR, 3rd, Wilson JW, Vetter EA et al. Optimal testing parameters for blood cultures. Clin Infect Dis 2004; 38: 1724-30.

4. Clinical and Laboratory Standards Institute. Principles and Procedures for Blood Cultures; Approved Guideline. CLSI Document M47-A (ISBN 1-56238-641-7): Clinical and Laboratory Standards Institute, 940 West Valley Road, Suite 1400, Wayne, Pennsylvania, 19087-1898, USA, 2007.

5. Weinstein MP, Reller LB, Murphy JR et al. The clinical significance of positive blood cultures: a comprehensive analysis of 500 episodes of bacteremia and fungemia in adults. I. Laboratory and epidemiologic observations. Rev Infect Dis 1983; 5: 35-53.

6. Vigano EF, Vasconi E, Agrappi $C$ et al. Use of simulated blood cultures for time to detection comparison between BacT/ALERT and BACTEC 9240 blood culture systems. Diagn Microbiol Infect Dis 2002; 44: 235-40.

7. Schwetz I, Hinrichs G, Reisinger EC et al. Delayed processing of blood samples influences time to positivity of blood cultures and results of Gram stain-acridine orange leukocyte Cytospin test. J Clin Microbiol 2007; 45: 2691-4.

8. Sautter RL, Bills AR, Lang DL et al. Effects of delayed-entry conditions on the recovery and detection of microorganisms from BacT/ALERT and BACTEC blood culture bottles. $J$ Clin Microbiol 2006; 44: 1245-9.

9. Saito $\mathrm{T}$, linuma $\mathrm{Y}$, Takakura $\mathrm{S}$ et al. Delayed insertion of blood culture bottles into automated continuously monitoring blood culture systems increases the time from blood sample collection to the detection of microorganisms in bacteremic patients. $J$ Infect Chemother 2009; 15: 49-53.

10. McKenzie R, Reimer LG. Effect of antimicrobials on blood cultures in endocarditis. Diagn Microbiol Infect Dis 1987; 8: 165-72.

11. Glerant JC, Hellmuth D, Schmit JL et al. Utility of blood cultures in community-acquired pneumonia requiring hospitalization: influence of antibiotic treatment before admission. Respir Med 1999; 93: 208-12.

12. Serody JS, Berrey MM, Albritton K et al. Utility of obtaining blood cultures in febrile neutropenic patients undergoing bone marrow transplantation. Bone Marrow Transplant 2000; 26 : 533-8.

13. Grace CJ, Lieberman J, Pierce $\mathrm{K}$ et al. Usefulness of blood culture for hospitalized patients who are receiving antibiotic therapy. Clin Infect Dis 2001; 32: 1651-5.

14. Hall KK, Lyman JA. Updated review of blood culture contamination. Clin Microbiol Rev 2006; 19: 788-802.

15. Angus DC, Linde-Zwirble WT, Lidicker $\mathrm{J}$ et al. Epidemiology of severe sepsis in the United States: analysis of incidence, outcome, and associated costs of care. Crit Care Med 2001; 29: 1303-10.

16. Dombrovskiy VY, Martin AA, Sunderram $\mathrm{J}$ et al. Rapid increase in hospitalization and mortality rates for severe sepsis in the United States: a trend analysis from 1993 to 2003. Crit Care Med 2007; 35: 1244-50.

17. Martin GS, Mannino DM, Eaton S et al. The epidemiology of sepsis in the United States from 1979 through 2000. N Engl J Med 2003; 348: 1546-54.

18. Angus DC, Wax RS. Epidemiology of sepsis: an update. Crit Care Med 2001; 29: S10916.

19. Lever A, Mackenzie I. Sepsis: definition, epidemiology, and diagnosis. Bmj 2007; 335: 879-83. 
20. Engel C, Brunkhorst FM, Bone HG et al. Epidemiology of sepsis in Germany: results from a national prospective multicenter study. Intensive Care Med 2007; 33: 606-18.

21. van Gestel A, Bakker J, Veraart CP et al. Prevalence and incidence of severe sepsis in Dutch intensive care units. Crit Care 2004; 8: R153-62.

22. Weinstein MP, Towns ML, Quartey SM et al. The clinical significance of positive blood cultures in the 1990s: a prospective comprehensive evaluation of the microbiology, epidemiology, and outcome of bacteremia and fungemia in adults. Clin Infect Dis 1997; 24: 584-602.

23. Leibovici L, Shraga I, Drucker $M$ et al. The benefit of appropriate empirical antibiotic treatment in patients with bloodstream infection. J Intern Med 1998; 244: 379-86.

24. Harbarth S, Garbino J, Pugin J et al. Inappropriate initial antimicrobial therapy and its effect on survival in a clinical trial of immunomodulating therapy for severe sepsis. $A m \mathrm{~J}$ Med 2003; 115: 529-35.

25. Ibrahim EH, Sherman G, Ward S et al. The influence of inadequate antimicrobial treatment of bloodstream infections on patient outcomes in the ICU setting. Chest 2000; 118: 146-55.

26. E. L. Weitere Mitteilungen über die Streptokokken-enteritis bei Saüglingen. Zentralb/ Bakteriol 1897; XXII: 376.

27. Levy MM, Fink MP, Marshall JC et al. 2001 SCCM/ESICM/ACCP/ATS/SIS International Sepsis Definitions Conference. Crit Care Med 2003; 31: 1250-6.

28. Reimer LG, Wilson ML, Weinstein MP. Update on detection of bacteremia and fungemia. Clin Microbiol Rev 1997; 10: 444-65.

29. Wisplinghoff HOURS, Bischoff T, Tallent SM et al. Nosocomial bloodstream infections in US hospitals: analysis of 24,179 cases from a prospective nationwide surveillance study. Clin Infect Dis 2004; 39: 309-17.

30. Edmond MB, Wallace SE, McClish DK et al. Nosocomial bloodstream infections in United States hospitals: a three-year analysis. Clin Infect Dis 1999; 29: 239-44.

31. Nobre V, Sarasin FP, Pugin J. Prompt antibiotic administration and goal-directed hemodynamic support in patients with severe sepsis and septic shock. Curr Opin Crit Care 2007; 13: 586-91.

32. Garnacho-Montero J, Garcia-Garmendia JL, Barrero-Almodovar A et al. Impact of adequate empirical antibiotic therapy on the outcome of patients admitted to the intensive care unit with sepsis. Crit Care Med 2003; 31: 2742-51.

33. Garnacho-Montero J, Ortiz-Leyba C, Herrera-Melero I et al. Mortality and morbidity attributable to inadequate empirical antimicrobial therapy in patients admitted to the ICU with sepsis: a matched cohort study. J Antimicrob Chemother 2008; 61: 436-41.

34. Mancini N, Carletti S, Ghidoli N et al. The era of molecular and other non-culture-based methods in diagnosis of sepsis. Clin Microbiol Rev 2010; 23: 235-51.

35. Vincent JL, Bihari DJ, Suter PM et al. The prevalence of nosocomial infection in intensive care units in Europe. Results of the European Prevalence of Infection in Intensive Care (EPIC) Study. EPIC International Advisory Committee. Jama 1995; 274: 639-44.

36. Richards MJ, Edwards JR, Culver DH et al. Nosocomial infections in medical intensive care units in the United States. National Nosocomial Infections Surveillance System. Crit Care Med 1999; 27: 887-92.

37. Beck-Sague C, Jarvis WR. Secular trends in the epidemiology of nosocomial fungal infections in the United States, 1980-1990. National Nosocomial Infections Surveillance System. J Infect Dis 1993; 167: 1247-51.

38. Shoham S, Marwaha S. Invasive fungal infections in the ICU. J Intensive Care Med 2010; 25: 78-92.

39. McNeil MM, Nash SL, Hajjeh RA et al. Trends in mortality due to invasive mycotic diseases in the United States, 1980-1997. Clin Infect Dis 2001; 33: 641-7.

40. Pfaller MA, Diekema DJ. Epidemiology of invasive candidiasis: a persistent public health problem. Clin Microbiol Rev 2007; 20: 133-63. 
41. Lewis RE. Overview of the changing epidemiology of candidemia. Curr Med Res Opin 2009; 25: 1732-40.

42. Einsele HOURS, Hebart HOURS, Roller G et al. Detection and identification of fungal pathogens in blood by using molecular probes. J Clin Microbiol 1997; 35: 1353-60.

43. White PL, Shetty A, Barnes RA. Detection of seven Candida species using the LightCycler system. J Med Microbiol 2003; 52: 229-38.

44. Odabasi Z, Mattiuzzi G, Estey E et al. Beta-D-glucan as a diagnostic adjunct for invasive fungal infections: validation, cutoff development, and performance in patients with acute myelogenous leukemia and myelodysplastic syndrome. Clin Infect Dis 2004; 39: 199-205.

45. Pfeiffer CD, Fine JP, Safdar N. Diagnosis of invasive aspergillosis using a galactomannan assay: a meta-analysis. Clin Infect Dis 2006; 42: 1417-27.

46. Metwally L, Fairley DJ, Coyle PV et al. Improving molecular detection of Candida DNA in whole blood: comparison of seven fungal DNA extraction protocols using real-time PCR. $J$ Med Microbiol 2008; 57: 296-303.

47. De Marco D, Perotti M, Ossi CM et al. Development and validation of a molecular method for the diagnosis of medically important fungal infections. New Microbiol 2007; 30: 308-12.

48. Mandviwala T, Shinde R, Kalra A et al. High-throughput identification and quantification of Candida species using high resolution derivative melt analysis of panfungal amplicons. $J$ Mol Diagn 2010; 12: 91-101.

49. Yagupsky P, Nolte FS. Quantitative aspects of septicemia. Clin Microbiol Rev 1990; 3: 269-79.

50. Arpi M, Bentzon MW, Jensen J et al. Importance of blood volume cultured in the detection of bacteremia. Eur J Clin Microbiol Infect Dis 1989; 8: 838-42.

51. Mermel LA, Maki DG. Detection of bacteremia in adults: consequences of culturing an inadequate volume of blood. Ann Intern Med 1993; 119: 270-2.

52. Kellogg JA, Manzella JP, Bankert DA. Frequency of low-level bacteremia in children from birth to fifteen years of age. J Clin Microbiol 2000; 38: 2181-5.

53. Bouza E, Alvarado N, Alcala $L$ et al. A randomized and prospective study of 3 procedures for the diagnosis of catheter-related bloodstream infection without catheter withdrawal. Clin Infect Dis 2007; 44: 820-6.

54. Jonsson B, Nyberg A, Henning C. Theoretical aspects of detection of bacteraemia as a function of the volume of blood cultured. Apmis 1993; 101: 595-601.

55. Isaacman DJ, Karasic RB, Reynolds EA et al. Effect of number of blood cultures and volume of blood on detection of bacteremia in children. $J$ Pediatr 1996; 128: 190-5.

56. Kaditis AG, O'Marcaigh AS, Rhodes $\mathrm{KH}$ et al. Yield of positive blood cultures in pediatric oncology patients by a new method of blood culture collection. Pediatr Infect Dis J 1996; 15: 615-20.

57. Fenollar F, Raoult D. Molecular diagnosis of bloodstream infections caused by noncultivable bacteria. Int J Antimicrob Agents 2007; 30 Suppl 1: S7-15.

58. Clinical and Laboratory Standards Institute. Abbreviated Identification of Bacteria and Yeast; Approved Guideline - Second Edition. CLSI document M35-A2 (ISBN 1-56238681-6): Clinical and Laboratory Standards Institute, 940 West Valley Road, Suite 1400, Wayne, Pennsylvania 19087-1898 USA, 2008.

59. Prendergast BD. The changing face of infective endocarditis. Heart 2006; 92: 879-85.

60. Socan M, Marinic-Fiser N, Kraigher A et al. Microbial aetiology of community-acquired pneumonia in hospitalised patients. Eur J Clin Microbiol Infect Dis 1999; 18: 777-82.

61. Shah SS, Downes KJ, Elliott MR et al. How long does it take to "rule out" bacteremia in children with central venous catheters? Pediatrics 2008; 121: 135-41.

62. Marra AR, Edmond MB, Forbes BA et al. Time to blood culture positivity as a predictor of clinical outcome of Staphylococcus aureus bloodstream infection. J Clin Microbiol 2006; 44: $1342-6$.

63. Peralta G, Rodriguez-Lera MJ, Garrido JC et al. Time to positivity in blood cultures of adults with Streptococcus pneumoniae bacteremia. BMC Infect Dis 2006; 6: 79. 
64. Peters RP, van Agtmael MA, Danner SA et al. New developments in the diagnosis of bloodstream infections. Lancet Infect Dis 2004; 4: 751-60.

65. Marvin LF, Roberts MA, Fay LB. Matrix-assisted laser desorption/ionization time-of-flight mass spectrometry in clinical chemistry. Clin Chim Acta 2003; 337: 11-21.

66. Anhalt J. P. CF. Identification of bacteria using massspectrometry. Anal Chem 1975; 47: 219-25.

67. Ryzhov V, Hathout Y, Fenselau C. Rapid characterization of spores of Bacillus cereus group bacteria by matrix-assisted laser desorption-ionization time-of-flight mass spectrometry. Appl Environ Microbiol 2000; 66: 3828-34.

68. Barbuddhe SB, Maier T, Schwarz G et al. Rapid identification and typing of listeria species by matrix-assisted laser desorption ionization-time of flight mass spectrometry. Appl Environ Microbiol 2008; 74: 5402-7.

69. Bernardo K, Pakulat N, Macht M et al. Identification and discrimination of Staphylococcus aureus strains using matrix-assisted laser desorption/ionization-time of flight mass spectrometry. Proteomics 2002; 2: 747-53.

70. Friedrichs C, Rodloff AC, Chhatwal GS et al. Rapid identification of viridans streptococci by mass spectrometric discrimination. J Clin Microbiol 2007; 45: 2392-7.

71. Grosse-Herrenthey A, Maier T, Gessler F et al. Challenging the problem of clostridial identification with matrix-assisted laser desorption and ionization-time-of-flight mass spectrometry (MALDI-TOF MS). Anaerobe 2008; 14: 242-9.

72. Moura HOURS, Woolfitt AR, Carvalho MG et al. MALDI-TOF mass spectrometry as a tool for differentiation of invasive and noninvasive Streptococcus pyogenes isolates. FEMS Immunol Med Microbiol 2008; 53: 333-42.

73. Conway GC, Smole SC, Sarracino DA et al. Phyloproteomics: species identification of Enterobacteriaceae using matrix-assisted laser desorption/ionization time-of-flight mass spectrometry. J Mol Microbiol Biotechnol 2001; 3: 103-12.

74. Degand N, Carbonnelle E, Dauphin B et al. Matrix-assisted laser desorption ionizationtime of flight mass spectrometry for identification of nonfermenting gram-negative bacilli isolated from cystic fibrosis patients. J Clin Microbiol 2008; 46: 3361-7.

75. Mellmann A, Bimet $F$, Bizet $C$ et al. High interlaboratory reproducibility of matrix-assisted laser desorption ionization-time of flight mass spectrometry-based species identification of nonfermenting bacteria. J Clin Microbiol 2009; 47: 3732-4.

76. Mellmann A, Cloud J, Maier $\mathrm{T}$ et al. Evaluation of matrix-assisted laser desorption ionization-time-of-flight mass spectrometry in comparison to 16S rRNA gene sequencing for species identification of nonfermenting bacteria. J Clin Microbiol 2008; 46: 1946-54.

77. Minan A, Bosch A, Lasch $P$ et al. Rapid identification of Burkholderia cepacia complex species including strains of the novel Taxon $\mathrm{K}$, recovered from cystic fibrosis patients by intact cell MALDI-ToF mass spectrometry. Analyst 2009; 134: 1138-48.

78. Hettick JM, Kashon ML, Slaven JE et al. Discrimination of intact mycobacteria at the strain level: a combined MALDI-TOF MS and biostatistical analysis. Proteomics 2006; 6: 641625.

79. Lefmann M, Honisch $\mathrm{C}$, Bocker S et al. Novel mass spectrometry-based tool for genotypic identification of mycobacteria. J Clin Microbiol 2004; 42: 339-46.

80. Pignone $\mathrm{M}$, Greth KM, Cooper $\mathrm{J}$ et al. Identification of mycobacteria by matrix-assisted laser desorption ionization-time-of-flight mass spectrometry. J Clin Microbiol 2006; 44: 1963-70.

81. Nagy E, Maier T, Urban E et al. Species identification of clinical isolates of Bacteroides by matrix-assisted laser-desorption/ionization time-of-flight mass spectrometry. Clin Microbiol Infect 2009; 15: 796-802.

82. Qian J, Cutler JE, Cole RB et al. MALDI-TOF mass signatures for differentiation of yeast species, strain grouping and monitoring of morphogenesis markers. Anal Bioanal Chem 2008; 392: 439-49. 
83. Marklein G, Josten M, Klanke $U$ et al. Matrix-assisted laser desorption ionization-time of flight mass spectrometry for fast and reliable identification of clinical yeast isolates. J Clin Microbiol 2009; 47: 2912-7.

84. Stevenson LG, Drake SK, Murray PR. Rapid identification of bacteria in positive blood culture broths by matrix-assisted laser desorption ionization-time of flight mass spectrometry. J Clin Microbiol 2010; 48: 444-7.

85. Ferreira L, Sanchez-Juanes F, Munoz-Bellido JL et al. Rapid method for direct identification of bacteria in urine and blood culture samples by matrix-assisted laser desorption ionization time-of-flight mass spectrometry: intact cell vs. extraction method. Clin Microbiol Infect 2011; 17: 1007-12.

86. La Scola B, Raoult D. Direct identification of bacteria in positive blood culture bottles by matrix-assisted laser desorption ionisation time-of-flight mass spectrometry. PLoS One 2009; 4: e8041.

87. Prod'hom G, Bizzini A, Durussel C et al. Matrix-assisted laser desorption ionization-time of flight mass spectrometry for direct bacterial identification from positive blood culture pellets. J Clin Microbiol 2010; 48: 1481-3.

88. Moussaoui W, Jaulhac B, Hoffmann AM et al. Matrix-assisted laser desorption ionization time-of-flight mass spectrometry identifies $90 \%$ of bacteria directly from blood culture vials. Clin Microbiol Infect 2010; 16: 1631-8.

89. Christner M, Rohde HOURS, Wolters M et al. Rapid identification of bacteria from positive blood culture bottles by use of matrix-assisted laser desorption-ionization time of flight mass spectrometry fingerprinting. J Clin Microbiol 2010; 48: 1584-91.

90. Drancourt M. Detection of microorganisms in blood specimens using matrix-assisted laser desorption ionization time-of-flight mass spectrometry: a review. Clin Microbiol Infect 2010; 16: 1620-5.

91. Raoult D, Fournier PE, Drancourt M. What does the future hold for clinical microbiology? Nat Rev Microbiol 2004; 2: 151-9.

92. Edwards-Jones V, Claydon MA, Evason DJ et al. Rapid discrimination between methicillin-sensitive and methicillin-resistant Staphylococcus aureus by intact cell mass spectrometry. J Med Microbiol 2000; 49: 295-300.

93. Walker J, Fox AJ, Edwards-Jones $\mathrm{V}$ et al. Intact cell mass spectrometry (ICMS) used to type methicillin-resistant Staphylococcus aureus: media effects and inter-laboratory reproducibility. J Microbiol Methods 2002; 48: 117-26.

94. Poppert S, Essig A, Marre R et al. Detection and differentiation of chlamydiae by fluorescence in situ hybridization. Appl Environ Microbiol 2002; 68: 4081-9.

95. Jansen GJ, Mooibroek M, Idema $J$ et al. Rapid identification of bacteria in blood cultures by using fluorescently labeled oligonucleotide probes. J Clin Microbiol 2000; 38: 814-7.

96. Sogaard M, Stender HOURS, Schonheyder HC. Direct identification of major blood culture pathogens, including Pseudomonas aeruginosa and Escherichia coli, by a panel of fluorescence in situ hybridization assays using peptide nucleic acid probes. $J$ Clin Microbiol 2005; 43: 1947-9.

97. Trebesius K, Adler K, Vieth M et al. Specific detection and prevalence of Helicobacter heilmannii-like organisms in the human gastric mucosa by fluorescent in situ hybridization and partial 16 S ribosomal DNA sequencing. J Clin Microbiol 2001; 39: 1510-6.

98. Trebesius K, Leitritz L, Adler $\mathrm{K}$ et al. Culture independent and rapid identification of bacterial pathogens in necrotising fasciitis and streptococcal toxic shock syndrome by fluorescence in situ hybridization. Med Microbiol Immunol 2000; 188: 169-75.

99. Kempf VA, Trebesius K, Autenrieth IB. Fluorescent In situ hybridization allows rapid identification of microorganisms in blood cultures. J Clin Microbiol 2000; 38: 830-8.

100. Peters RP, Savelkoul PH, Simoons-Smit AM et al. Faster identification of pathogens in positive blood cultures by fluorescence in situ hybridization in routine practice. $J$ Clin Microbiol 2006; 44: 119-23. 
101. Barken KB, Haagensen JA, Tolker-Nielsen T. Advances in nucleic acid-based diagnostics of bacterial infections. Clin Chim Acta 2007; 384: 1-11.

102. Handschur M, Karlic HOURS, Hertel $C$ et al. Preanalytic removal of human DNA eliminates false signals in general 16S rDNA PCR monitoring of bacterial pathogens in blood. Comp Immunol Microbiol Infect Dis 2009; 32: 207-19.

103. Al-Soud WA, Radstrom P. Purification and characterization of PCR-inhibitory components in blood cells. J Clin Microbiol 2001; 39: 485-93.

104. Radstrom $P$, Knutsson $R$, Wolffs $P$ et al. Pre-PCR processing: strategies to generate PCR-compatible samples. Mol Biotechnol 2004; 26: 133-46.

105. Queipo-Ortuno MI, Garcia-Ordonez MA, Colmenero JD et al. Hydrogen peroxide improves the efficiency of a peripheral blood PCR assay for diagnosis of human brucellosis. Biotechniques 1999; 27: 248-50, 52.

106. Muhl HOURS, Kochem AJ, Disque $\mathrm{C}$ et al. Activity and DNA contamination of commercial polymerase chain reaction reagents for the universal $16 \mathrm{~S}$ rDNA real-time polymerase chain reaction detection of bacterial pathogens in blood. Diagn Microbiol Infect Dis 2010; 66: 41-9.

107. Evans GE, Murdoch DR, Anderson TP et al. Contamination of Qiagen DNA extraction kits with Legionella DNA. J Clin Microbiol 2003; 41: 3452-3.

108. van der Zee A, Peeters $M$, de Jong $C$ et al. Qiagen DNA extraction kits for sample preparation for legionella PCR are not suitable for diagnostic purposes. J Clin Microbiol 2002; 40: 1126.

109. Rantakokko-Jalava K, Jalava J. Optimal DNA isolation method for detection of bacteria in clinical specimens by broad-range PCR. J Clin Microbiol 2002; 40: 4211-7.

110. Bretagne S, Costa JM. Towards a molecular diagnosis of invasive aspergillosis and disseminated candidosis. FEMS Immunol Med Microbiol 2005; 45: 361-8.

111. Al-Soud WA, Jonsson LJ, Radstrom P. Identification and characterization of immunoglobulin $\mathrm{G}$ in blood as a major inhibitor of diagnostic PCR. J Clin Microbiol 2000; 38: 345-50.

112. Queipo-Ortuno MI, Tena F, Colmenero JD et al. Comparison of seven commercial DNA extraction kits for the recovery of Brucella DNA from spiked human serum samples using real-time PCR. Eur J Clin Microbiol Infect Dis 2008; 27: 109-14.

113. Riemann K, Adamzik M, Frauenrath $S$ et al. Comparison of manual and automated nucleic acid extraction from whole-blood samples. J Clin Lab Anal 2007; 21: 244-8.

114. Smith K, Diggle MA, Clarke SC. Comparison of commercial DNA extraction kits for extraction of bacterial genomic DNA from whole-blood samples. J Clin Microbiol 2003; 41: 2440-3.

115. Handschur M, Karlic HOURS, Hertel $C$ et al. Preanalytic removal of human DNA eliminates false signals in general 16S rDNA PCR monitoring of bacterial pathogens in blood. Comp Immunol Microbiol Infect Dis 2009; 32: 207-19.

116. Wiesinger-Mayr HOURS, Jordana-Lluch E, Martro E et al. Establishment of a semiautomated pathogen DNA isolation from whole blood and comparison with commercially available kits. J Microbiol Methods 2011; 85: 206-13.

117. Horz HP, Scheer S, Huenger $F$ et al. Selective isolation of bacterial DNA from human clinical specimens. J Microbiol Methods 2008; 72: 98-102.

118. Horz HP, Scheer S, Vianna ME et al. New methods for selective isolation of bacterial DNA from human clinical specimens. Anaerobe 2010; 16: 47-53.

119. Fredricks DN, Relman DA. Improved amplification of microbial DNA from blood cultures by removal of the PCR inhibitor sodium polyanetholesulfonate. J Clin Microbiol 1998; 36: 2810-6.

120. Millar BC, Jiru X, Moore JE et al. A simple and sensitive method to extract bacterial, yeast and fungal DNA from blood culture material. J Microbiol Methods 2000; 42: 139-47. 
121. Tan TY, Corden S, Barnes $R$ et al. Rapid identification of methicillin-resistant Staphylococcus aureus from positive blood cultures by real-time fluorescence PCR. J Clin Microbiol 2001; 39: 4529-31.

122. Jaffe RI, Lane JD, Albury SV et al. Rapid extraction from and direct identification in clinical samples of methicillin-resistant staphylococci using the PCR. J Clin Microbiol 2000; 38: 3407-12.

123. Louie L, Goodfellow J, Mathieu P et al. Rapid detection of methicillin-resistant staphylococci from blood culture bottles by using a multiplex PCR assay. J Clin Microbiol 2002; 40: 2786-90.

124. Selva L, Esteva C, Gene A et al. Direct detection of Streptococcus pneumoniae in positive blood cultures by real-time polymerase chain reaction. Diagn Microbiol Infect Dis 2010; 66: 204-6.

125. Harris KA, Turner P, Green EA et al. Duplex real-time PCR assay for detection of Streptococcus pneumoniae in clinical samples and determination of penicillin susceptibility. J Clin Microbiol 2008; 46: 2751-8.

126. Loonen AJ, Jansz AR, Kreeftenberg HOURS et al. Acceleration of the direct identification of Staphylococcus aureus versus coagulase-negative staphylococci from blood culture material: a comparison of six bacterial DNA extraction methods. Eur J Clin Microbiol Infect Dis 2011; 30: 337-42.

127. Gebert S, Siegel D, Wellinghausen N. Rapid detection of pathogens in blood culture bottles by real-time PCR in conjunction with the pre-analytic tool MolYsis. $J$ Infect 2008; 57: 307-16.

128. Klouche M, Schroder U. Rapid methods for diagnosis of bloodstream infections. Clin Chem Lab Med 2008; 46: 888-908.

129. Mullis KB, Faloona FA. Specific synthesis of DNA in vitro via a polymerase-catalyzed chain reaction. Methods Enzymol 1987; 155: 335-50.

130. Fredricks DN, Relman DA. Application of polymerase chain reaction to the diagnosis of infectious diseases. Clin Infect Dis 1999; 29: 475-86; quiz 87-8.

131. leven M, Goossens HOURS. Relevance of nucleic acid amplification techniques for diagnosis of respiratory tract infections in the clinical laboratory. Clin Microbiol Rev 1997; 10: 242-56.

132. Persing DH. Diagnostic molecular microbiology. Current challenges and future directions. Diagn Microbiol Infect Dis 1993; 16: 159-63.

133. Tang YW, Procop GW, Persing DH. Molecular diagnostics of infectious diseases. Clin Chem 1997; 43: 2021-38.

134. Bankowski M. J. ASM. Real-time nucleic acid amplification in clinical microbiology. Clin Microbiol News/ 2004; 26: 9-15.

135. Mackay IM. Real-time PCR in the microbiology laboratory. Clin Microbiol Infect 2004; 10: 190-212.

136. Smith TF, Uhl JR, Espy MJ et al. Development, implementation, and trend analysis of real-time PCR tests for the clinical microbiology laboratory. Clin Microbiol News/ 2004; 26 : 145-54.

137. Cockerill FR, 3rd. Application of rapid-cycle real-time polymerase chain reaction for diagnostic testing in the clinical microbiology laboratory. Arch Pathol Lab Med 2003; 127: 1112-20.

138. Cockerill FR, Uhl JR. Applications and challenges of real-time PCR for the clinical microbiology laboratory. In: Reischl U, Wittwer C, Cockerill FR, eds. Rapid cycle real-time PCR methods and applications: Springer-Verlag, Berlin, Germany, 2002; 3-27.

139. Uhl JR, Cockerill III F. R. The fluorescence resonance energy transfer system. Molecular Microbiology, 2004; 295-306.

140. Espy MJ, Uhl JR, Sloan LM et al. Real-time PCR in clinical microbiology: applications for routine laboratory testing. Clin Microbiol Rev 2006; 19: 165-256. 
141. Song JH, Cho HOURS, Park MY et al. Detection of Salmonella typhi in the blood of patients with typhoid fever by polymerase chain reaction. J Clin Microbiol 1993; 31: 143943.

142. Sanchez-Jimenez MM, Cardona-Castro N. Validation of a PCR for diagnosis of typhoid fever and salmonellosis by amplification of the hilA gene in clinical samples from Colombian patients. J Med Microbiol 2004; 53: 875-8.

143. Iwase T, Hoshina S, Seki $\mathrm{K}$ et al. Rapid identification and specific quantification of Staphylococcus epidermidis by $5^{\prime}$ nuclease real-time polymerase chain reaction with a minor groove binder probe. Diagn Microbiol Infect Dis 2008; 60: 217-9.

144. Brakstad OG, Aasbakk K, Maeland JA. Detection of Staphylococcus aureus by polymerase chain reaction amplification of the nuc gene. J Clin Microbiol 1992; 30: 165460.

145. Martineau F, Picard FJ, Roy PH et al. Species-specific and ubiquitous-DNA-based assays for rapid identification of Staphylococcus aureus. J Clin Microbiol 1998; 36: 618-23.

146. Wellinghausen N, Siegel D, Gebert S et al. Rapid detection of Staphylococcus aureus bacteremia and methicillin resistance by real-time PCR in whole blood samples. Eur J Clin Microbiol Infect Dis 2009; 28: 1001-5.

147. Thomas LC, Gidding HF, Ginn AN et al. Development of a real-time Staphylococcus aureus and MRSA (SAM-) PCR for routine blood culture. J Microbiol Methods 2007; 68: 296-302.

148. Costa AM, Kay I, Palladino S. Rapid detection of mecA and nuc genes in staphylococci by real-time multiplex polymerase chain reaction. Diagn Microbiol Infect Dis 2005; 51: 13-7.

149. Elsayed S, Chow BL, Hamilton NL et al. Development and validation of a molecular beacon probe-based real-time polymerase chain reaction assay for rapid detection of methicillin resistance in Staphylococcus aureus. Arch Pathol Lab Med 2003; 127: 845-9.

150. Hassan-King M, Baldeh I, Secka O et al. Detection of Streptococcus pneumoniae DNA in blood cultures by PCR. J Clin Microbiol 1994; 32: 1721-4.

151. Lorente ML, Falguera M, Nogues A et al. Diagnosis of pneumococcal pneumonia by polymerase chain reaction (PCR) in whole blood: a prospective clinical study. Thorax 2000; 55: 133-7.

152. Wheeler J, Murphy OM, Freeman R et al. PCR can add to detection of pneumococcal disease in pneumonic patients receiving antibiotics at admission. $J$ Clin Microbiol 2000; 38: 3907.

153. Zhang Y, Isaacman DJ, Wadowsky RM et al. Detection of Streptococcus pneumoniae in whole blood by PCR. J Clin Microbiol 1995; 33: 596-601.

154. Newcombe J, Cartwright K, Palmer WH et al. PCR of peripheral blood for diagnosis of meningococcal disease. J Clin Microbiol 1996; 34: 1637-40.

155. Guiver M, Borrow R, Marsh $\mathrm{J}$ et al. Evaluation of the Applied Biosystems automated Taqman polymerase chain reaction system for the detection of meningococcal DNA. FEMS Immunol Med Microbiol 2000; 28: 173-9.

156. Folgueira L, Delgado R, Palenque E et al. Rapid diagnosis of Mycobacterium tuberculosis bacteremia by PCR. J Clin Microbiol 1996; 34: 512-5.

157. Schluger NW, Condos R, Lewis $S$ et al. Amplification of DNA of Mycobacterium tuberculosis from peripheral blood of patients with pulmonary tuberculosis. Lancet 1994; 344: 232-3.

158. Rebollo MJ, San Juan Garrido R, Folgueira D et al. Blood and urine samples as useful sources for the direct detection of tuberculosis by polymerase chain reaction. Diagn Microbiol Infect Dis 2006; 56: 141-6.

159. Maaroufi Y, Heymans C, De Bruyne JM et al. Rapid detection of Candida albicans in clinical blood samples by using a TaqMan-based PCR assay. J Clin Microbiol 2003; 41: 3293-8.

160. Kami M, Fukui T, Ogawa S et al. Use of real-time PCR on blood samples for diagnosis of invasive aspergillosis. Clin Infect Dis 2001; 33: 1504-12. 
161. Chen CC, Teng LJ, Chang TC. Identification of clinically relevant viridans group streptococci by sequence analysis of the 16S-23S ribosomal DNA spacer region. J Clin Microbiol 2004; 42: 2651-7.

162. Kiratisin P, Li L, Murray PR et al. Identification of bacteria recovered from clinical specimens by $16 \mathrm{~S}$ rRNA gene sequencing. Eur J Clin Microbiol Infect Dis 2003; 22: 62831.

163. Patel JB. 16S rRNA gene sequencing for bacterial pathogen identification in the clinical laboratory. Mol Diagn 2001; 6: 313-21.

164. Khot PD, Ko DL, Fredricks DN. Sequencing and analysis of fungal rRNA operons for development of broad-range fungal PCR assays. Appl Environ Microbiol 2009; 75: 155965.

165. Nakamura A, Sugimoto $\mathrm{Y}$, Ohishi $\mathrm{K}$ et al. Diagnostic value of PCR analysis of bacteria and fungi from blood in empiric-therapy-resistant febrile neutropenia. J Clin Microbiol 2010; 48: 2030-6.

166. Gray MW, Sankoff D, Cedergren RJ. On the evolutionary descent of organisms and organelles: a global phylogeny based on a highly conserved structural core in small subunit ribosomal RNA. Nucleic Acids Res 1984; 12: 5837-52.

167. Clarridge JE, 3rd. Impact of $16 \mathrm{~S}$ rRNA gene sequence analysis for identification of bacteria on clinical microbiology and infectious diseases. Clin Microbiol Rev 2004; 17: 840-62.

168. Kane TD, Alexander JW, Johannigman JA. The detection of microbial DNA in the blood: a sensitive method for diagnosing bacteremia and/or bacterial translocation in surgical patients. Ann Surg 1998; 227: 1-9.

169. Rothman RE, Majmudar MD, Kelen GD et al. Detection of bacteremia in emergency department patients at risk for infective endocarditis using universal 16S rRNA primers in a decontaminated polymerase chain reaction assay. J Infect Dis 2002; 186: 1677-81.

170. Shang S, Chen G, Wu Y et al. Rapid diagnosis of bacterial sepsis with PCR amplification and microarray hybridization in 16S rRNA gene. Pediatr Res 2005; 58: 143-8.

171. Sleigh J, Cursons R, La Pine M. Detection of bacteraemia in critically ill patients using $16 S$ rDNA polymerase chain reaction and DNA sequencing. Intensive Care Med 2001; 27: 1269-73.

172. Van Burik JA, Myerson D, Schreckhise RW et al. Panfungal PCR assay for detection of fungal infection in human blood specimens. J Clin Microbiol 1998; 36: 1169-75.

173. Ley BE, Linton CJ, Bennett DM et al. Detection of bacteraemia in patients with fever and neutropenia using $16 \mathrm{~S}$ rRNA gene amplification by polymerase chain reaction. Eur J Clin Microbiol Infect Dis 1998; 17: 247-53.

174. Millar MR, Johnson G, Wilks M et al. Molecular diagnosis of vascular access deviceassociated infection in children being treated for cancer or leukaemia. Clin Microbiol Infect 2008; 14: 213-20.

175. Harris KA, Hartley JC. Development of broad-range 16S rDNA PCR for use in the routine diagnostic clinical microbiology service. J Med Microbiol 2003; 52: 685-91.

176. Rantakokko-Jalava K, Nikkari S, Jalava J et al. Direct amplification of rRNA genes in diagnosis of bacterial infections. J Clin Microbiol 2000; 38: 32-9.

177. Ratanarat R, Cazzavillan S, Ricci Z et al. Usefulness of a molecular strategy for the detection of bacterial DNA in patients with severe sepsis undergoing continuous renal replacement therapy. Blood Purif 2007; 25: 106-11.

178. Vliegen I, Jacobs JA, Beuken E et al. Rapid identification of bacteria by real-time amplification and sequencing of the 16S rRNA gene. J Microbiol Methods 2006; 66: 15664.

179. Sontakke S, Cadenas MB, Maggi RG et al. Use of broad range16S rDNA PCR in clinical microbiology. J Microbiol Methods 2009; 76: 217-25. 
180. Chiba N, Murayama SY, Morozumi M et al. Rapid detection of eight causative pathogens for the diagnosis of bacterial meningitis by real-time PCR. $J$ Infect Chemother 2009; 15: 92-8.

181. Corless CE, Guiver M, Borrow R et al. Simultaneous detection of Neisseria meningitidis, Haemophilus influenzae, and Streptococcus pneumoniae in suspected cases of meningitis and septicemia using real-time PCR. J Clin Microbiol 2001; 39: 1553-8.

182. Wellinghausen N, Wirths B, Franz AR et al. Algorithm for the identification of bacterial pathogens in positive blood cultures by real-time LightCycler polymerase chain reaction (PCR) with sequence-specific probes. Diagn Microbiol Infect Dis 2004; 48: 229-41.

183. Wu YD, Chen LH, Wu XJ et al. Gram stain-specific-probe-based real-time PCR for diagnosis and discrimination of bacterial neonatal sepsis. J Clin Microbiol 2008; 46: 26139.

184. Yang S, Ramachandran P, Hardick A et al. Rapid PCR-based diagnosis of septic arthritis by early Gram-type classification and pathogen identification. J Clin Microbiol 2008; 46: 1386-90.

185. LightCycler SeptiFast Test Package Insert. Roche Diagnostics GmbH, 2006.

186. Lehmann LE, Hunfeld KP, Steinbrucker $M$ et al. Improved detection of blood stream pathogens by real-time PCR in severe sepsis. Intensive Care Med 2010; 36: 49-56.

187. Obara HOURS, Aikawa N, Hasegawa $N$ et al. The role of a real-time PCR technology for rapid detection and identification of bacterial and fungal pathogens in whole-blood samples. J Infect Chemother 2011; 17: 327-33.

188. Tsalik EL, Jones D, Nicholson B et al. Multiplex PCR to diagnose bloodstream infections in patients admitted from the emergency department with sepsis. J Clin Microbiol 2010; 48: 26-33.

189. Yanagihara K, Kitagawa $\mathrm{Y}$, Tomonaga $\mathrm{M}$ et al. Evaluation of pathogen detection from clinical samples by real-time polymerase chain reaction using a sepsis pathogen DNA detection kit. Crit Care 2010; 14: R159.

190. Lucignano B, Ranno S, Liesenfeld O et al. Multiplex PCR allows rapid and accurate diagnosis of bloodstream infections in newborns and children with suspected sepsis. $J$ Clin Microbiol 2011; 49: 2252-8.

191. Gaibani P, Rossini G, Ambretti $S$ et al. Blood culture systems: rapid detection--how and why? Int J Antimicrob Agents 2009; 34 Suppl 4: S13-5.

192. Wellinghausen N, Kochem AJ, Disque C et al. Diagnosis of bacteremia in whole-blood samples by use of a commercial universal 16S rRNA gene-based PCR and sequence analysis. J Clin Microbiol 2009; 47: 2759-65.

193. Leggieri N, Rida A, Francois $P$ et al. Molecular diagnosis of bloodstream infections: planning to (physically) reach the bedside. Curr Opin Infect Dis 2010; 23: 311-9.

194. Hackett SJ, Guiver M, Marsh J et al. Meningococcal bacterial DNA load at presentation correlates with disease severity. Arch Dis Child 2002; 86: 44-6.

195. Peters RP, de Boer RF, Schuurman T et al. Streptococcus pneumoniae DNA load in blood as a marker of infection in patients with community-acquired pneumonia. $J$ Clin Microbiol 2009; 47: 3308-12.

196. Kee C, Palladino S, Kay I et al. Feasibility of real-time polymerase chain reaction in whole blood to identify Streptococcus pneumoniae in patients with community-acquired pneumonia. Diagn Microbiol Infect Dis 2008; 61: 72-5.

197. Nicolle LE, Bradley S, Colgan R et al. Infectious Diseases Society of America guidelines for the diagnosis and treatment of asymptomatic bacteriuria in adults. Clin Infect Dis 2005; 40: 643-54.

198. Itahashi M, Higaki S, Fukuda $\mathrm{M}$ et al. Detection and quantification of pathogenic bacteria and fungi using real-time polymerase chain reaction by cycling probe in patients with corneal ulcer. Arch Ophthalmol 2010; 128: 535-40. 
199. Peters RP, van Agtmael MA, Gierveld S et al. Quantitative detection of Staphylococcus aureus and Enterococcus faecalis DNA in blood to diagnose bacteremia in patients in the intensive care unit. J Clin Microbiol 2007; 45: 3641-6.

200. van Haeften R, Palladino S, Kay I et al. A quantitative LightCycler PCR to detect Streptococcus pneumoniae in blood and CSF. Diagn Microbiol Infect Dis 2003; 47: 40714.

201. Rothman R, Ramachandran P, Yang S et al. Use of quantitative broad-based polymerase chain reaction for detection and identification of common bacterial pathogens in cerebrospinal fluid. Acad Emerg Med 2010; 17: 741-7.

202. Navarro E, Segura JC, Castano MJ et al. Use of real-time quantitative polymerase chain reaction to monitor the evolution of Brucella melitensis DNA load during therapy and posttherapy follow-up in patients with brucellosis. Clin Infect Dis 2006; 42: 1266-73.

203. Ovstebo R, Brandtzaeg P, Brusletto B et al. Use of robotized DNA isolation and real-time PCR to quantify and identify close correlation between levels of Neisseria meningitidis DNA and lipopolysaccharides in plasma and cerebrospinal fluid from patients with systemic meningococcal disease. J Clin Microbiol 2004; 42: 2980-7.

204. Kollef $\mathrm{MH}$. Inadequate antimicrobial treatment: an important determinant of outcome for hospitalized patients. Clin Infect Dis 2000; 31 Suppl 4: S131-8.

205. Bergeron MG, Ouellette M. Preventing antibiotic resistance through rapid genotypic identification of bacteria and of their antibiotic resistance genes in the clinical microbiology laboratory. J Clin Microbiol 1998; 36: 2169-72.

206. Courvalin P. Genotypic approach to the study of bacterial resistance to antibiotics. Antimicrob Agents Chemother 1991; 35: 1019-23.

207. Tenover FC. Bauer and Kirby meets Watson and Crick: antimicrobial susceptibility testing in the molecular era. ASM News 1992; 58: 669-72.

208. Shrestha NK, Tuohy MJ, Hall GS et al. Rapid identification of Staphylococcus aureus and the mecA gene from BacT/ALERT blood culture bottles by using the LightCycler system. $J$ Clin Microbiol 2002; 40: 2659-61.

209. Reischl U, Linde HJ, Metz $M$ et al. Rapid identification of methicillin-resistant Staphylococcus aureus and simultaneous species confirmation using real-time fluorescence PCR. J Clin Microbiol 2000; 38: 2429-33.

210. Killgore GE, Holloway B, Tenover FC. A 5' nuclease PCR (TaqMan) high-throughput assay for detection of the mecA gene in staphylococci. J Clin Microbiol 2000; 38: 2516-9.

211. Huletsky A, Giroux R, Rossbach V et al. New real-time PCR assay for rapid detection of methicillin-resistant Staphylococcus aureus directly from specimens containing a mixture of staphylococci. J Clin Microbiol 2004; 42: 1875-84.

212. Hallin M, Maes N, Byl B et al. Clinical impact of a PCR assay for identification of Staphylococcus aureus and determination of methicillin resistance directly from blood cultures. J Clin Microbiol 2003; 41: 3942-4.

213. Fang HOURS, Hedin G. Rapid screening and identification of methicillin-resistant Staphylococcus aureus from clinical samples by selective-broth and real-time PCR assay. J Clin Microbiol 2003; 41: 2894-9.

214. Francois $\mathrm{P}$, Pittet $\mathrm{D}$, Bento $\mathrm{M}$ et al. Rapid detection of methicillin-resistant Staphylococcus aureus directly from sterile or nonsterile clinical samples by a new molecular assay. $J$ Clin Microbiol 2003; 41: 254-60.

215. Chambers HF. Methicillin resistance in staphylococci: molecular and biochemical basis and clinical implications. Clin Microbiol Rev 1997; 10: 781-91.

216. de Lencastre HOURS, de Jonge BL, Matthews PR et al. Molecular aspects of methicillin resistance in Staphylococcus aureus. J Antimicrob Chemother 1994; 33: 7-24.

217. Hartman BJ, Tomasz A. Low-affinity penicillin-binding protein associated with beta-lactam resistance in Staphylococcus aureus. J Bacteriol 1984; 158: 513-6.

218. Lowy FD. Antimicrobial resistance: the example of Staphylococcus aureus. J Clin Invest 2003; 111: 1265-73. 
219. Sundsfjord A, Simonsen GS, Haldorsen BC et al. Genetic methods for detection of antimicrobial resistance. Apmis 2004; 112: 815-37.

220. Fluit AC, Visser MR, Schmitz FJ. Molecular detection of antimicrobial resistance. Clin Microbiol Rev 2001; 14: 836-71, table of contents.

221. Emaneini M, Taherikalani M, Eslampour MA et al. Phenotypic and genotypic evaluation of aminoglycoside resistance in clinical isolates of staphylococci in Tehran, Iran. Microb Drug Resist 2009; 15: 129-32.

222. Leclercq R. Mechanisms of resistance to macrolides and lincosamides: nature of the resistance elements and their clinical implications. Clin Infect Dis 2002; 34: 482-92.

223. Perreten V, Vorlet-Fawer L, Slickers $\mathrm{P}$ et al. Microarray-based detection of 90 antibiotic resistance genes of gram-positive bacteria. J Clin Microbiol 2005; 43: 2291-302.

224. Frye JG, Jesse $\mathrm{T}$, Long $\mathrm{F}$ et al. DNA microarray detection of antimicrobial resistance genes in diverse bacteria. Int $J$ Antimicrob Agents 2006; 27: 138-51.

225. Strommenger B, Schmidt C, Werner $G$ et al. DNA microarray for the detection of therapeutically relevant antibiotic resistance determinants in clinical isolates of Staphylococcus aureus. Mol Cell Probes 2007; 21: 161-70.

226. Zhu LX, Zhang ZW, Wang C et al. Use of a DNA microarray for simultaneous detection of antibiotic resistance genes among staphylococcal clinical isolates. J Clin Microbiol 2007; 45: 3514-21.

227. Martineau F, Picard FJ, Grenier L et al. Multiplex PCR assays for the detection of clinically relevant antibiotic resistance genes in staphylococci isolated from patients infected after cardiac surgery. The ESPRIT Trial. J Antimicrob Chemother 2000; 46: 527-34.

228. Martineau F, Picard FJ, Lansac $N$ et al. Correlation between the resistance genotype determined by multiplex PCR assays and the antibiotic susceptibility patterns of Staphylococcus aureus and Staphylococcus epidermidis. Antimicrob Agents Chemother 2000; 44: 231-8.

229. Strommenger B, Kettlitz C, Werner G et al. Multiplex PCR assay for simultaneous detection of nine clinically relevant antibiotic resistance genes in Staphylococcus aureus. J Clin Microbiol 2003; 41: 4089-94.

230. Sabet NS, Subramaniam G, Navaratnam $P$ et al. Detection of methicillin- and aminoglycoside-resistant genes and simultaneous identification of $S$. aureus using triplex real-time PCR Taqman assay. J Microbiol Methods 2007; 68: 157-62.

231. Zhang K, Sparling J, Chow BL et al. New quadriplex PCR assay for detection of methicillin and mupirocin resistance and simultaneous discrimination of Staphylococcus aureus from coagulase-negative staphylococci. J Clin Microbiol 2004; 42: 4947-55. 



\section{Chapter 2a}

\section{Evaluation of new preanalysis sample treatment tools and DNA isolation protocols to improve bacterial pathogen detection in whole blood}




\section{Abstract}

Two novel preanalysis sample treatment tools were evaluated in combination with four DNA extraction kits for the selective isolation of bacterial DNA from whole blood. The combination of performing a preanalysis sample treatment and using a larger sample volume increased the detection limit to 50 colonyforming units (cfu) per ml. 


\section{Introduction}

New approaches, using molecular technologies are continuously being developed to improve the diagnosis of bloodstream infections. A critical issue in the success of the application of molecular methods is the sample treatment and/or nucleic acid isolation ${ }^{1}$. The low concentration of pathogens and the presence of PCR-inhibitory compounds in blood are important challenges that should be dealt with during sample treatment ${ }^{2-6}$. This could be done with so called preanalysis sample treatment tools, which combine selective enrichment of bacterial DNA from blood with integrated, highly efficient removal of PCR inhibitors. The aim of this study was to determine whether the addition of a preanalysis sample treatment to a selective DNA extraction protocol could improve the amplification and detection of bacterial DNA from whole blood samples.

\section{Material and methods}

MolYsis Basic (MolZym, Bremen, Germany) and Looxster (SIRS-lab, Jena, Germany) were evaluated as novel preanalysis sample treatment tools in combination with QIAamp DNA Blood Mini Kit (Qiagen, Hilden, Germany), MagNA Pure LC Microbiology Kit $M^{\text {Grade }}$ (Roche Diagnostics, Mannheim, Germany), MolYsis Complete Kit (MolZym, Bremen, Germany) and MagSi-DNA Isolation Kit for Blood (MagnaMedics Diagnostics, Maastricht, The Netherlands). A schematic overview of the performed analytical processes for whole blood spiked with methicillin-resistant Staphylococcus aureus (MRSA) is given in Figure 1. Bacterial DNA extraction was followed by amplification in a multiplex real-time PCR assay targeting three MRSA genes (mecA, femA and sa442) ${ }^{7}$. Real-time PCR was set up in a final volume of $50 \mu \mathrm{l}$ with $2 \times$ Absolute $^{\mathrm{TM}}$ QPCR ROX (500 nM) Mix (Abgene, Epsom, United Kingdom). Primers and probes were purchased from Sigma-Genosys (Haverhill, United Kingdom) and Applied Biosystems (Nieuwerkerk a/d ljssel, The Netherlands), respectively. Final reactions contained $0.6 \mu \mathrm{M}$ of $\operatorname{mec} A$ primer and $0.3 \mu \mathrm{M}$ of femA and sa442 primer, $100 \mathrm{nM}, 125 \mathrm{nM}$ and $150 \mathrm{nM}$ of femA, mecA and sa442 probe respectively and $18.85 \mu \mathrm{l}$ of template DNA. Optimal thermal cycling conditions were as follows: initial denaturation at $95^{\circ} \mathrm{C}$ for $15 \mathrm{~min}, 42$ cycles of denaturation for $15 \mathrm{~s}$ at $95^{\circ} \mathrm{C}$ and annealing at $60^{\circ} \mathrm{C}$ for $1 \mathrm{~min}$. 


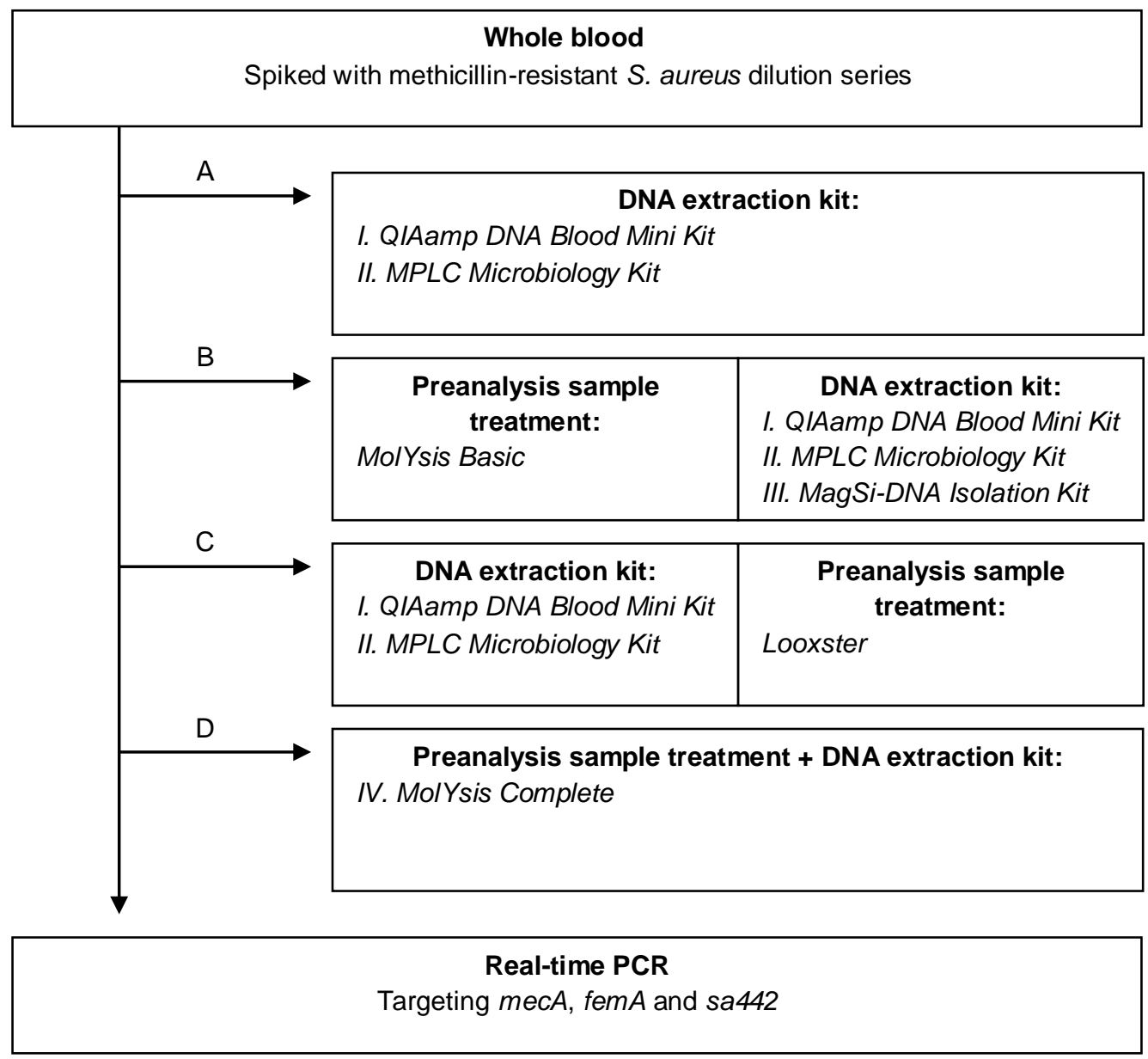

Figure 1. Schematic overview of the analytical process for whole blood samples. A, DNA extraction with two conventional kits, without preanalysis sample treatment. B, DNA extraction with two conventional kits and one novel kit, following preanalysis sample treatment with MolYsis Basic. C, DNA extraction with two conventional kits, followed by a preanalysis sample treatment with Looxster. D, DNA extraction with a novel kit, which combines all the steps of the preanalysis sample treatment (MolYsis Basic) with a complementary matching DNA extraction protocol.

\section{Results and discussion}

The detection limit of all DNA extraction procedures was determined and is presented in Table 1. Two conventional DNA extraction kits (QIAamp and MPLC) were tested with and without two different preanalysis sample treatment protocols. Preanalysis sample treatment, either with MolYsis Basis or Looxster, 
combined with QIAamp extraction, based on a spin-column format, did not result in an increase in detection limit. Both procedures performed equally and were able to detect three target genes at a minimal concentration of $10^{3}$ cfu per $\mathrm{ml}$, which was analogous to $16 \mathrm{cfu}$ per PCR.

Table 1. Lower detection limits of the MRSA real-time PCR assay in relation to preanalysis sample treatment with MolYsis Basic/Looxster and DNA extraction protocol used.

DNA-extraction

Detection limit ${ }^{a}$, no. of cfu/ml

method

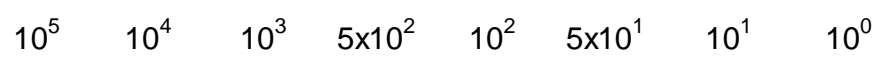

QIAamp

QIAamp + M.Basic ${ }^{b}$

QIAamp + Looxster ${ }^{c}$

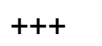

$+++$

$+++$

n.d. ${ }^{d}$

$---$

n.d.

MPLC

MPLC + M.Basic

+++

$+++$

+++
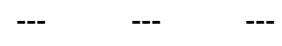

$+++$

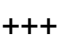

$+++$

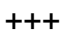

MagSi-DNA + M.Basic

$+++$

+++

$++$

$+-$

Complete

$++\quad++$

t+t

$+++$

$+++$

$+++$

${ }^{a}$ Detection represented by a Ct-value $<40$ is indicated by + , no detection is indicated by -, detection was determined for the three gene targets ( $m e c A$, femA and sa442). The data represent results from three independent replicate experiments.

${ }^{b}$ MolYsis Basic, preanalysis sample treatment for removal of human DNA and bacteria. enrichment in whole blood samples.

${ }^{c}$ Looxster, preanalysis sample treatment for the enrichment of bacterial DNA from total DNA.

${ }^{d}$ n.d., not determined.

Recently, a study by Horz et al. investigated if MolYsis Basic could indeed eliminate human DNA in oral samples to improve the detection of bacterial $\mathrm{DNA}^{8}$. They found that use of MolYsis Basic prior to DNA isolation reduced the level of human DNA. However, this effect was accompanied with a partial loss of bacterial DNA. The MPLC kit performed the same as the QIAamp kit, i.e. a detection limit of $10^{3}$ cfu per ml. The MPLC kit in combination with MolYsis Basic could detect $500 \mathrm{cfu}$ per ml. However, when combined with Looxster, the minimal detectable amount of bacteria was $10^{4}$ cfu per $\mathrm{ml}$ (data not shown). 
This was most likely due to incompatibility of the Looxster Kit and the MPLC elution buffer, which is essential to the performance of the MPLC kit.

The MagSi-DNA kit and the Complete kit represented two novel procedures for targeted isolation of bacterial DNA (Table 1). The MagSi-DNA kit, a novel combination of two sample preparation methods, showed results similar to the results obtained after conventional DNA extraction. The minimal detectable amount of bacteria was $10^{3}$ cfu per $\mathrm{ml}$. MolYsis Complete was able to achieve bacterial detection at a concentration of $50 \mathrm{cfu}$ per $\mathrm{ml}$ and therefore achieved the lowest detection limit compared to all other DNA extraction methods. In this case, the detection of $50 \mathrm{cfu}$ per $\mathrm{ml}$ was analogous to $4 \mathrm{cfu}$ per PCR. MolYsis Complete provides a combination of preanalysis sample treatment and targeted DNA extraction containing all the buffers and reagents necessary for human DNA removal, bacteria enrichment and bacterial DNA extraction. These findings suggest that the combination of two complementary matching sample preparation procedures and the use of a larger volume of blood sample both contributed to a higher level of bacterial detection. Few studies in the past have focused on pathogen detection in whole blood samples, instead experiments were performed using bacterial suspensions or clinical sample materials such as pleural fluid, pus, synovial fluid and pericardial fluid ${ }^{9,10}$. Zucol et al. evaluated different DNA extraction protocols for whole blood samples followed by broadrange real-time PCR, targeting the 16S rDNA gene in Staphylococcus aureus and Escherichia coli. They achieved the detection of bacterial concentrations of $>10$ cfu per PCR, which was analogous to $10^{3}$ cfu per $\mathrm{ml}^{11}$.

Automation, ease of use, duration and costs of the procedure are each important factors also contributing to the extent of implementation in diagnostic laboratories. Table 2 shows the detection limit, the duration in time and the cost per sample obtained for the different DNA isolation protocols. Except for the MPLC Kit, which is performed on the automated MagNA Pure Instrument, all procedures are performed manually. The extraction methods were all considered as easy to perform. The hands-on time for the manual DNA isolation methods combined with sample pre-treatment varied between 120 and 240 minutes.

In conclusion, we investigated whether the addition of a preanalysis sample treatment could improve the efficiency of purifying bacterial DNA from whole blood samples. The combination of performing a preanalysis sample treatment and using a larger sample volume achieved the detection of only $50 \mathrm{cfu}$ per $\mathrm{ml}$ of whole blood ( $<5$ cfu per reaction), emphasizing that the rate of efficiency was attributed to more than one factor. These results confirmed that the efficiency of DNA extraction, especially for clinical samples such as whole blood, is a crucial element in the process of molecular pathogen detection. Ultimately, a combination of optimal sample processing and molecular detection techniques 
will lead to rapid and accurate pathogen detection for diagnosis of bloodstream infections.

Table 2. Comparative analysis of the different DNA extraction procedures performed on whole blood spiked with a 10 -fold dilution series of MRSA.

\begin{tabular}{|c|c|c|c|c|}
\hline DNA extraction method & $\begin{array}{l}\mathrm{V}_{\mathrm{b}}{ }^{\mathrm{a}} \\
(\mathrm{ml})\end{array}$ & $\begin{array}{l}\text { Detection limit } \\
\quad(\mathrm{cfu} / \mathrm{ml})\end{array}$ & $\begin{array}{c}\operatorname{Cost}^{b} \\
(€)\end{array}$ & $\begin{array}{l}T^{T i m e}{ }^{c} \\
(\mathrm{~min})\end{array}$ \\
\hline QIAamp & 0.2 & $10^{3}$ & 2.56 & 90 \\
\hline QIAamp + M.Basic ${ }^{d}$ & 0.2 & $10^{3}$ & 7.06 & 175 \\
\hline QIAamp + Looxster ${ }^{e}$ & 0.2 & $10^{3}$ & 32.56 & 240 \\
\hline MPLC & 0.1 & $10^{3}$ & 2.27 & 40 \\
\hline MPLC + M.Basic & 0.2 & $5 \times 10^{2}$ & 6.77 & 125 \\
\hline MagSi-DNA + M.Basic & 0.2 & $10^{3}$ & n.a. ${ }^{f}$ & 130 \\
\hline Complete & 1.0 & $5 \times 10^{1}$ & 9.70 & 120 \\
\hline
\end{tabular}

${ }^{a}$ Blood volume in $\mathrm{ml}$.

${ }^{b}$ Price per sample for reagents, not included are plastic wares not provided in the kit.

${ }^{c}$ Hands-on time for eight samples.

${ }^{d}$ MolYsis Basic, preanalysis sample treatment for removal of human DNA and bacteria enrichment in whole blood samples.

${ }^{e}$ Looxster, preanalysis sample treatment for the enrichment of bacterial DNA from total DNA.

${ }^{f}$ n.a., not available.

\section{References}

1. Barken KB, Haagensen JA, Tolker-Nielsen T. Advances in nucleic acid-based diagnostics of bacterial infections. Clin Chim Acta 2007; 384: 1-11.

2. Al-Soud WA, Radstrom P. Purification and characterization of PCR-inhibitory components in blood cells. J Clin Microbiol 2001; 39: 485-93.

3. Kreader CA. Relief of amplification inhibition in PCR with bovine serum albumin or T4 gene 32 protein. Appl Environ Microbiol 1996; 62: 1102-6.

4. Morata P, Queipo-Ortuno MI, de Dios Colmenero J. Strategy for optimizing DNA amplification in a peripheral blood PCR assay used for diagnosis of human brucellosis. $J$ Clin Microbiol 1998; 36: 2443-6.

5. Smith K, Diggle MA, Clarke SC. Comparison of commercial DNA extraction kits for extraction of bacterial genomic DNA from whole-blood samples. J Clin Microbiol 2003; 41: 2440-3. 


\section{CHAPTER 2a}

6. Wilson IG. Inhibition and facilitation of nucleic acid amplification. Appl Environ Microbiol 1997; 63: 3741-51.

7. Donker GA, Deurenberg $\mathrm{RH}$, Driessen $\mathrm{C}$ et al. The population structure of Staphylococcus aureus among general practice patients from The Netherlands. Clin Microbiol Infect 2009; 15: 137-43.

8. Horz HP, Scheer S, Huenger $F$ et al. Selective isolation of bacterial DNA from human clinical specimens. J Microbiol Methods 2008; 72: 98-102.

9. Klaschik S, Lehmann LE, Raadts $A$ et al. Detection and differentiation of in vitro-spiked bacteria by real-time PCR and melting-curve analysis. J Clin Microbiol 2004; 42: 512-7.

10. Rantakokko-Jalava K, Jalava J. Optimal DNA isolation method for detection of bacteria in clinical specimens by broad-range PCR. J Clin Microbiol 2002; 40: 4211-7.

11. Zucol F, Ammann RA, Berger $C$ et al. Real-time quantitative broad-range PCR assay for detection of the 16S rRNA gene followed by sequencing for species identification. J Clin Microbiol 2006; 44: 2750-9. 




\section{Chapter 2b}

\section{Pathogen diagnostics for bloodstream infections: bacterial load issues}

Wendy L. J. Hansen, Judith Beuving, Cathrien A. Bruggeman, Petra F. G. Wolffs 


\section{Abstract}

In pediatric whole blood specimens, quantification of the bacterial concentration was determined to gain more insights into the requirements needed for pathogen diagnostics. In $46 \%$ of the positive blood cultures, colony counts between 20 and 760 colony-forming units (cfu) per $\mathrm{ml}$ of whole blood were found. In the remaining samples, no bacteria could be detected without prior enrichment. 


\section{Introduction}

Molecular diagnostics have proven to be successful in the detection of bacterial and viral targets present in high-load patient samples such as cultured materials and faecal samples. However, patient material containing a very low amount of bacteria such as whole blood cannot be analyzed using this rapid and highthroughput approach. As a consequence, whole blood needs culturing, causing a delay of approximately 1-2 days. Methods have been proposed to improve identification of pathogens from whole blood and these are mostly based on the elimination of human DNA and the enrichment of bacterial DNA. So far, only a limited number of studies have been done concerning the bacterial concentration in blood of septic patients, and these have shown contrasting results. In adults, studies have shown that patients contained between 1 and $100 \mathrm{cfu} / \mathrm{ml}$ of blood ${ }^{1}$. Furthermore, it is commonly thought that the amount of bacteria is much higher in children, especially in neonates ${ }^{1}$. This, however, can be debated, since reports by Kellogg et al. showed the occurrence of low-level bacteraemia $(\leq 10 \mathrm{cfu} / \mathrm{ml})$ in $60-70 \%$ of their population ${ }^{2}$. In this study, we wanted to investigate the bacterial load present in children, which could be useful for the determination of diagnostic test requirements in this patient population.

\section{Material and methods}

In total, we collected 61 pediatric whole blood samples from the department of Pediatrics at the Maastricht University Medical Center (MUMC+, Maastricht, The Netherlands). Whole blood specimens drawn from children suspected of having a bloodstream infection were included in the study if microbial growth was detected in the corresponding blood culture. Pediatric blood culture bottles (BACTEC Peds Plus ${ }^{\text {TM }}$, BD Diagnostic Systems) were incubated and monitored for microbial growth in the Bactec 9240 automated blood culture device (BD Diagnostic Systems). Standard conventional testing was performed for bacterial identification. Because of the small amount $(<1 \mathrm{ml})$ of whole blood available from children, $50 \mu \mathrm{l}$ of whole blood was used for direct inoculation on Columbia sheep blood agar plates (BD Diagnostic Systems). After overnight incubation, colony counting was performed for the determination of the bacterial load.

\section{Results}

In thirteen blood cultures, which were simultaneously drawn, pathogens were found, whereas $79 \%$ of the blood cultures were negative for bacteria. In six of 
thirteen cases (46\%), we could also find bacteria in the whole blood sample (Table 1).

Table 1. Bacterial load determined in whole blood samples of children with a positive blood culture.

\begin{tabular}{|c|c|c|c|}
\hline \multicolumn{2}{|c|}{$\frac{\text { blood culture positive }}{\text { whole blood positive }}$} & \multicolumn{2}{|c|}{$\frac{\text { blood culture positive }}{\text { whole blood negative }}$} \\
\hline $\begin{array}{l}\text { Bacterial load } \\
\text { in whole blood }\end{array}$ & Pathogen & $\begin{array}{l}\text { Bacterial load } \\
\text { in whole blood }\end{array}$ & Pathogen \\
\hline $20 \mathrm{cfu} / \mathrm{ml}$ & CoNS & $<20 \mathrm{cfu} / \mathrm{ml}$ & CoNS \\
\hline $20 \mathrm{cfu} / \mathrm{ml}$ & CoNS & $<20 \mathrm{cfu} / \mathrm{ml}$ & CoNS \\
\hline $40 \mathrm{cfu} / \mathrm{ml}$ & S. aureus & $<20 \mathrm{cfu} / \mathrm{ml}$ & CoNS \\
\hline $20 \mathrm{cfu} / \mathrm{ml}$ & S. aureus & $<20 \mathrm{cfu} / \mathrm{ml}$ & CoNS \\
\hline $760 \mathrm{cfu} / \mathrm{ml}$ & CoNS & $<20 \mathrm{cfu} / \mathrm{ml}$ & CoNS \\
\hline \multirow[t]{2}{*}{$420 \mathrm{cfu} / \mathrm{ml}$} & CoNS & $<20 \mathrm{cfu} / \mathrm{ml}$ & Non-fermenter \\
\hline & & $<20 \mathrm{cfu} / \mathrm{ml}$ & Bacillus cereus \\
\hline
\end{tabular}

CoNS, coagulase-negative Staphylococcus species

The whole blood specimens positive for bacteria showed colony counts between 20 and $760 \mathrm{cfu} / \mathrm{ml}$. Colony counts of $<20 \mathrm{cfu} / \mathrm{ml}$ could not be detected since this corresponded with less than one colony inoculated from $50 \mu \mathrm{l}$ of whole blood. This was the case in seven whole blood specimens in which no bacteria were grown, suggesting low-level bacteraemia, not detectable without enrichment. The pathogens found to be present in the blood cultures were Staphyloccocus aureus $(\mathrm{n}=2)$, coagulase-negative Staphylococcus species (CoNS) ( $n=9)$, one Bacillus cereus and one non-fermenter.

\section{Discussion}

These findings pointed out the diversity in bacterial load in children suspicious of having a bloodstream infection. Only two out of thirteen whole blood specimens that matched with a positive blood culture contained more than 50 $\mathrm{cfu} / \mathrm{ml}$. In the first section of this chapter, we discussed the performance capacities of different DNA extraction protocols and evaluated novel tools for the specific enrichment of bacterial DNA. The detection limit of the most optimal DNA extraction protocol combined with a multiplex real-time PCR was 50 $\mathrm{cfu} / \mathrm{ml}$. From that perspective, the molecular detection of pathogens would only be accomplished in two out of thirteen whole blood specimens. The remaining specimens would be missed since less than $50 \mathrm{cfu} / \mathrm{ml}$ were present. Jordan et al. developed a real-time PCR assay based on 16S rDNA targeting for the detection of bacterial DNA directly from neonatal whole blood. In their study, 56 
spiking experiments were performed to determine the limit of detection. The assay, which used a QIAamp DNA Mini Kit (Qiagen, Hilden, Germany) for the bacterial DNA extraction, was capable of detecting 40,50 , or $2000 \mathrm{cfu} / \mathrm{ml}$ of Escherichia coli, group B Streptococcus, and Listeria monocytogenes, respectively ${ }^{3}$. Next, the assay was evaluated using a cohort of 53 neonates with culture-proven sepsis, and only two samples failed to be detected ${ }^{3}$. However, it can be questioned to what extent the PCR signal is related to the amount of dead or living bacterial cells, especially in cases of culture-proven sepsis, and in patients receiving antibiotics. Instead, the samples we used for the quantification of the bacterial load were drawn at disease onset from children with unexplained fever, and this was done at admission, before antibiotics were given. Differences in bacterial load can be attributable to several factors such as severity of disease and the pathogen involved. Another report on the diagnosis of bacterial neonatal sepsis found a higher positivity rate with real-time PCR than with blood culture ${ }^{4}$. This was also the case in a recent report presented by Lucignano et al. in which they evaluated a multiplex PCR (the LightCycler SeptiFast test, Roche Diagnostics, Mannheim, Germany) for the direct detection of bacteria and fungi from pediatric blood samples. The analytical sensitivity of this test, as indicated by the manufacturer, was between 3 and $100 \mathrm{cfu} / \mathrm{ml}$, depending on the pathogen involved ${ }^{5}$. To clarify the contribution of dead cells, future studies would have to include colony counts of living bacterial cells from whole blood samples, and this in parallel with molecular analysis of the samples. Evaluation of diverse real-time PCR assays showed potential to become a more rapid approach of pathogen diagnostics, offering results within a few hours. Though, it remains to be established whether detection of low-level bacteremia can be achieved. For that reason, blood cultures still remain the diagnostic tool of choice for the detection of bacterial infections.

\section{References}

1. Yagupsky P, Nolte FS. Quantitative aspects of septicemia. Clin Microbiol Rev 1990; 3: 269-79.

2. Kellogg JA, Manzella JP, Bankert DA. Frequency of low-level bacteremia in children from birth to fifteen years of age. J Clin Microbiol 2000; 38: 2181-5.

3. Jordan JA, Durso MB. Real-time polymerase chain reaction for detecting bacterial DNA directly from blood of neonates being evaluated for sepsis. J Mol Diagn 2005; 7: 575-81.

4. Wu YD, Chen LH, Wu XJ et al. Gram stain-specific-probe-based real-time PCR for diagnosis and discrimination of bacterial neonatal sepsis. J Clin Microbiol 2008; 46: 26139.

5. Lucignano B, Ranno S, Liesenfeld $O$ et al. Multiplex PCR allows rapid and accurate diagnosis of bloodstream infections in newborns and children with suspected sepsis. $J$ Clin Microbiol 2011; 49: 2252-8. 



\section{Chapter 3a}

\section{Molecular probes for the diagnosis of clinically relevant bacterial infections in blood cultures}

Wendy L. J. Hansen, Judith Beuving, Cathrien A. Bruggeman, Petra F. G. Wolffs Journal of Clinical Microbiology (2010) 48(12):4432-4438 


\section{Abstract}

Broad-range real-time PCR and sequencing of the $16 \mathrm{~S}$ rDNA gene region is a widely known method for the detection and identification of bacteria in clinical samples. However, because of the need for sequencing, such identification of bacteria is time-consuming. The aim of our study was to develop a more rapid $16 S$ real-time PCR-based identification assay using species or genus-specific probes. The Gram-negative bacteria were divided in Pseudomonas spp., Pseudomonasaeruginosa,Escherichia coli and other Gram-negatives. Within the Gram-positives, probes were designed for Staphylococcus spp., Staphylococcusaureus, Enterococcus spp., Streptococcus spp., and Streptococcuspneumoniae. The assay also included a universal probe within the 16S rDNA gene for the detection of all bacterial DNA. The assay was evaluated on a collection of 248 blood cultures. In this study, the universal probe and the probes targeting Pseudomonas spp., P.aeruginosa, E. coli, Streptococcus spp., S.pneumoniae, Enterococcus spp., and Staphylococcus spp. all had a sensitivity and specificity of $100 \%$. The probe for $S$. aureus showed eight discrepancies resulting in a sensitivity of $100 \%$ and a specificity of $93 \%$. This data showed a high agreement between conventional testing and our novel real-time PCR assay. Furthermore, this assay significantly reduced the time needed for identification. In conclusion, using pathogen-specific probes offers a faster alternative for pathogen detection and could improve the diagnosis of bloodstream infections. 


\section{Introduction}

Bloodstream infections (BSIs) are a major cause of death in the world and need a thorough and adequate therapeutic strategy. Inadequate antibiotic therapy is associated with higher mortality rates, the appearance of antibiotic resistance and longer hospitalisation length of stay ${ }^{1}$. Conventional identification and susceptibility testing have several limitations, such as lack of rapidity and sensitivity. The current gold standard, i.e. blood culture, usually requires 6-12 hours of incubation before growth is detected and a further 24-48 hours for the definitive identification of the infectious agent and its susceptibility to antibiotics ${ }^{2}$, ${ }^{3}$. Routine diagnostics already use molecular techniques for the direct detection of viral and bacterial pathogens. However, most in-house assays are targeted against one specific bacterium and/or virus and do not offer a broad-range pathogen detection. Recently, several PCR assays have been developed targeting a panel of the most relevant bacterial and fungal bloodstream pathogens, which can be performed directly from blood, such as SeptiFast (Roche Diagnostics, Mannheim, Germany), SepsiTest (MolZym, Bremen, Germany), and VYOO (SIRS-Lab, Jena, Germany), or from positive blood cultures, such as the microarray-based system Prove-itSepsis (Mobidiag, Helsinki, Finland).

As discussed in our previous work ${ }^{4}$, direct detection in whole blood is hampered by several factors such as the presence of PCR inhibitors and background DNA, low bacterial load, insufficient sensitivity and the difficulty of establishing an assay capable of detecting a wide range of pathogens. In contrast, molecular testing of growth-positive blood cultures do not require highly sensitive assays because of the presence of a high bacterial load. Furthermore, until now culturing remains essential to determine the microorganism's antimicrobial profile. Therefore, the role of blood cultures remains important for the detection and identification of bacterial causative agents. Molecular testing of blood cultures, possibly in combination with conventional testing, could enable a more rapid identification, and consequently a more rapid diagnosis and start of correct therapy. Molecular approaches such as broad-range real-time PCR and sequencing of the $16 \mathrm{~S}$ rDNA gene region are widely known methods for the detection and identification of bacteria in clinical samples ${ }^{5-8}$. However, because of the need for sequencing, the identification of bacteria is time-consuming.

The aim of our study was to develop a more rapid $16 \mathrm{~S}$ real-time PCR-based identification assay using species or genus-specific probes. The assay is particularly intended for identification of positive blood cultures, of which Gram staining results are known. In this proof-of-concept study, priority was given to the genera or species most frequently found in blood cultures and/or those that could direct the choice of a suitable antibiotic therapy. Therefore, we selected a panel of eight species or genus-specific probes. The Gram-negative bacteria 
were divided into Pseudomonas spp., P. aeruginosa, E. coli and other Gramnegatives. Within the Gram-positives probes were designed for Staphylococcus spp., S. aureus, Enterococcus spp., Streptococcus spp., and S. pneumoniae. Hence, a first indication about the causative microorganism is given after two hours, while confirmation and precise identification can be achieved with sequencing. Consequently, multiple species can be detected in samples with a polymicrobial infection. The present paper reports a retrospective study performed on blood cultures obtained from patients with suspected bloodstream infections. Results of this new multi-probe assay were compared with conventional blood culture findings.

\section{Material and methods}

\section{Clinical samples}

A total of 248 blood cultures were collected at the Maastricht University Medical Center (MUMC+, Maastricht, The Netherlands). All samples were analyzed with standard conventional testing. Blood drawn from patients suspected for bloodstream infection was incubated in blood culture bottles (Plus+Aerobic (product no. 442192;BD Diagnostic Systems, Sparks, MD, USA) and Plus+Anaerobic (product no. 442193; BD) and monitored for microbial growth in the Bactec ${ }^{\mathrm{TM}} 9240$ automated blood culture device (BD Diagnostic Systems). When growth was detected, Gram-staining was performed. A small aliquot of each blood culture $(1 \mathrm{ml})$ was requested for the novel molecular assay. Two separate assays were developed for Gram-negative and Gram-positive bacteria, respectively. Hence, further analysis was based on the results of Gram-staining.

\section{Conventional bacterial identification}

Regarding the Gram-positive cocci: to discern Staphylococcus spp. from other Gram-positive cocci (GPCs), a catalase test was performed by adding one colony to a drop of $3 \% \mathrm{H}_{2} \mathrm{O}_{2}$. For the identification of Staphylococcus spp., catalase-positive strains were tested for coagulase and DNase production. If both tests were negative, the strain was identified as a coagulase-negative Staphylococcus (CoNS). To discern Enterococcus spp. from other catalasenegative GPCs, bile esculin, tellur diagnostic tablets (Rosco Diagnostica, Taastrup, Denmark) and an API 20 Strep test (Biomérieux SA, Marcy l'Etoile, France) were used, according to manufacturer's guidelines. Optochin susceptibility (OXOID, Hampshire, United Kingdom) was used to differentiate $S$. pneumoniae from the other viridans streptococci, which were further identified by API 20 Strep. In case of $\beta$-hemolytic streptococci, latex agglutination was 
performed using the Prolex Streptococcal Grouping Latex kit (Bio Trading, product code PL.030).

\section{Bacterial strains}

Reference strains were used to validate the specificity of the assay, including $S$. aureus ATCC 25923 and 29213, Staphylococcus epidermidis ATCC 12228 and 14990, S. pneumoniae ATCC 49619, $P$. aeruginosa ATCC 27853, Enterococcus faecalis ATCC 29212, Enterococcus faecium BM 4147, and E. coli ATCC 35218.

\section{Multi-probe assay}

An aliquot $(0.1 \mathrm{ml})$ of blood culture was 1:100 diluted in $0.9 \% \mathrm{NaCl}$. Dilutions were centrifuged for $5 \mathrm{~min}$ at $12.000 \mathrm{rpm}$ and the bacterial pellet was resuspended in $100 \mu \mathrm{l}$ NASBA $\mathrm{H}_{2} \mathrm{O}$. The primers and the universal bacterial TaqMan probe have been described previously ${ }^{9}$. The probes for $P$. aeruginosa, Pseudomonas spp., E. coli, Staphylococcus spp., S. aureus, Enterococcus spp., Streptococcus spp., and $S$. pneumoniae were designed by using the BLAST tool and ClustalW software. Multiple sequence alignments were made and are partly shown in Figure 1. The designed probe sequences are given in Table 1. All primers and probes were tested for specificity and cross-reactions both manually and with use of the NCBI-BLAST tool (http://www.ncbi.nlm.nih.gov/BLAST). Primer and probe matrices were performed to determine optimal concentrations. Each test contained $5 \mu \mathrm{l}$ purified sample and $20 \mu \mathrm{l}$ reaction mixture. The reaction mixture contained 12.5 $\mu \mathrm{l}$ of Taqman Environmental Master Mix 2.0 (Applied Biosystems, Foster City, California, United States), $0.9 \mu \mathrm{M}$ of forward primer, $0.6 \mu \mathrm{M}$ of reverse primer, and $0.2 \mu \mathrm{M}$ of each probe. There were three separate reactions. The first reaction included the universal probe and $P$. aeruginosa probe. The second reaction contained the E. coli and Pseudomonas spp. probe. The third reaction included the Staphylococcus spp. probe, the $S$. aureus probe and the Enterococcus spp. probe, the third and final reaction the Streptococcus spp. probe and the $S$. pneumoniae probe. Reactions were performed on the $A B I$ PRISM7000 real-time PCR System (Applied Biosystems, Foster City, California, United States) and optimal thermal cycling conditions were as follows: 2 min at $50^{\circ} \mathrm{C}$, initial denaturation at $95^{\circ} \mathrm{C}$ for $15 \mathrm{~min}, 42$ cycles of denaturation for $15 \mathrm{~s}$ at $95^{\circ} \mathrm{C}$ and annealing at $60^{\circ} \mathrm{C}$ for $1 \mathrm{~min}$. Cycle threshold $(\mathrm{Ct})$, the cycle number at which amplicon fluorescence exceeded the preset detection threshold, was recorded for all samples. The cut-off value to consider a PCR result as positive was set to a Ct of 35 . 


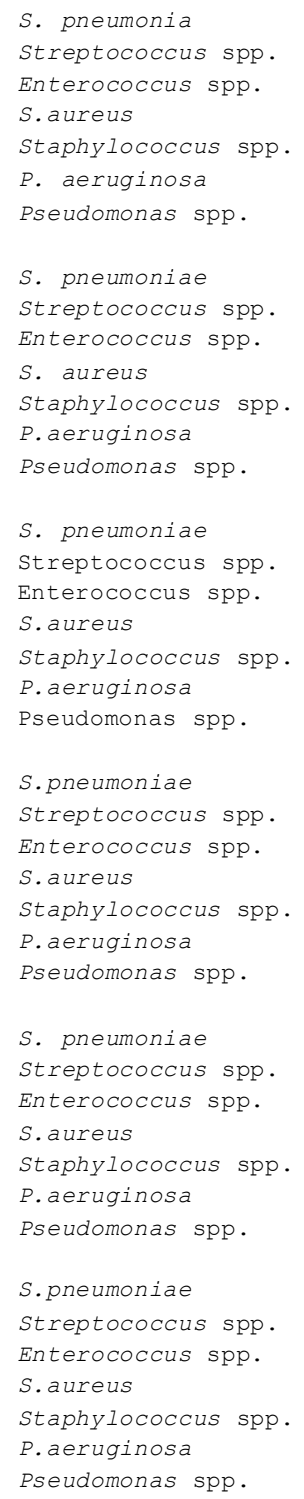

TCCTACGGGAGGCAGCAGTAGGGAATCTTCGGCAATGGACGGAAGTCTGA 50 TCCTACGGGAGGCAGCAGTAGGGAATCTTCGGCAATGGGGGCAACCCTGA 50 TCCTACGGGAGGCAGCAGTAGGGAATCTTCGGCAATGGACGAAAGTCTGA 50 TCCTACGGGAGGCAGCAGTAGGGAATCTTCCGCAATGGGCGAAAGCCTGA 50 a TCCTACGGGAGGCAGCAGTAGGGAATCTTCCGCAATGGGCGAAAGCCTGA 50 a TCCTACGGGAGGCAGCAGTGGGGAATATTGGACAATGGGCGAAAGCCTGA 50 TCCTACGGGAGGCAGCAGTGGGGAATATTGGACAATGGGCGAAAGCCTGA $50 \rightarrow$

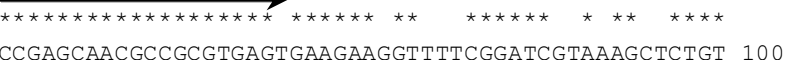
CCGAGCAACGCCGCGTGAGTGAAGAAGGTTTTCGGATCGTAAAGCTCTGT 100 CCGAGCAACGCCGCGTGAGTGAAGAAGGTTTTCGGATCGTAAAACTCTGT $100 \mathrm{~b}$ CGGAGCAACGCCGCGTGAGTGATGAAGGTCTTCGGATCGTAAAACTCTGT 100 CGGAGCAACGCCGCGTGAGTGATGAAGGTCTTCGGATCGTAAAGCTCTGT 100 TCCAGCCATGCCGCGTGTGTGAAGAAGGTCTTCGGATTGTAAAGCACTTT $100 \mathrm{C}$ TCCAGCCATGCCGCGTGTGTGAAGAAGGTCTTCGGATTGTAAAGCACTTT $100 \mathrm{C}$

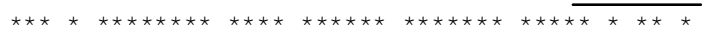

TGTAAGAGAAGAACGGTGTGAGAGTGGAAAGTTCACACTGTGACGGTAT 150 TGTAAGAGAAGATGTGTGTGGGAGTGGAAAGTCCACATAATGACGGTAT 150 TGTTAGAGAAGAACAAGGATGAGAGTAGAACGTTCATCCCTTGACGGTAT 150 b TATTAGGGAAGAACATATGTGTAAGTA-ACTGTGCACATCTTGACGGTAC 149 d TATTAGGGAAGAACAAACGTGTAAGTA-ACTGTGCACGTCTTGACGGTAC 149 AAGTTGGGAGGAAGGGCAGT-AAGTTAATACCTTGCTGTTTTGACGTTAC $149 \mathrm{C}$ AAGTTGGGAGGAAGG GCAGT-TACCTAATACGTAATTGTTTTGACGTTAC $149 \mathrm{C}$

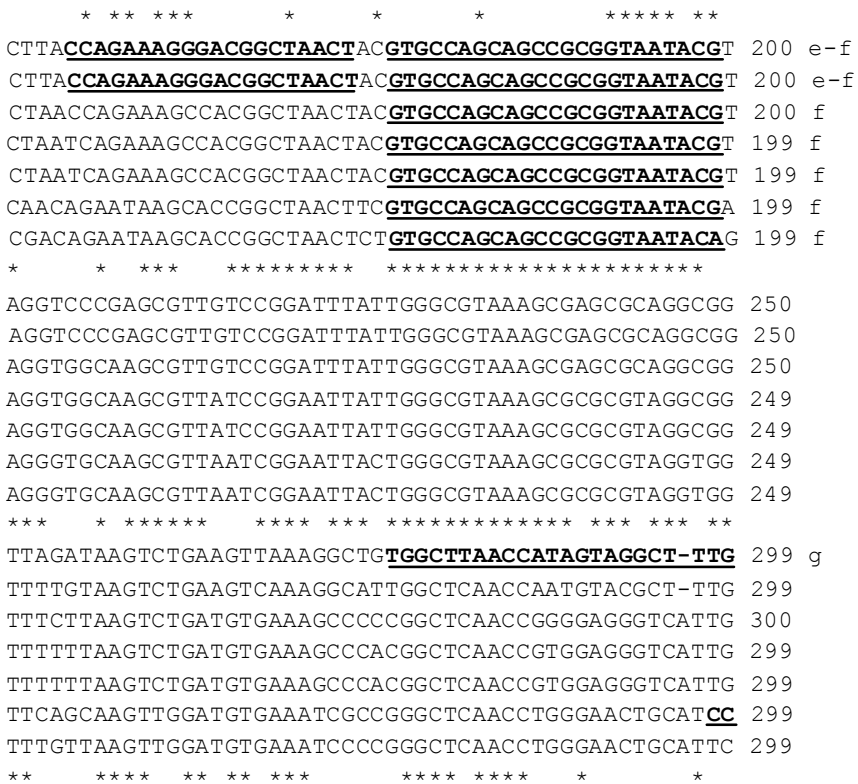

Figure 1. Multiple sequence alignments of the amplified part of the bacterial $16 \mathrm{~S}$ gene. Sequences are shown of the bacteria included in the multi-probe assay. The arrows $(\leftarrow \rightarrow)$ represent the forward and reverse primer targeting the $16 \mathrm{~S}$ gene. The sequences of the probes are in bold and underlined: (a) Staphylococcus spp. probe. (b) Enterococcus spp. probe. (c) Pseudomonas spp. probe. (d) S. aureus probe. (e) Streptococcus spp. probe. (f) Universal probe. (g) $S$. pneumoniae probe. (h) $P$. aeruginosa probe. 


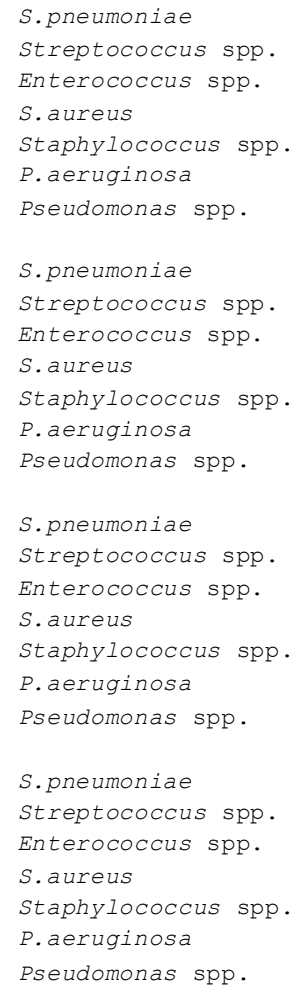

Figure 1.-Continued.

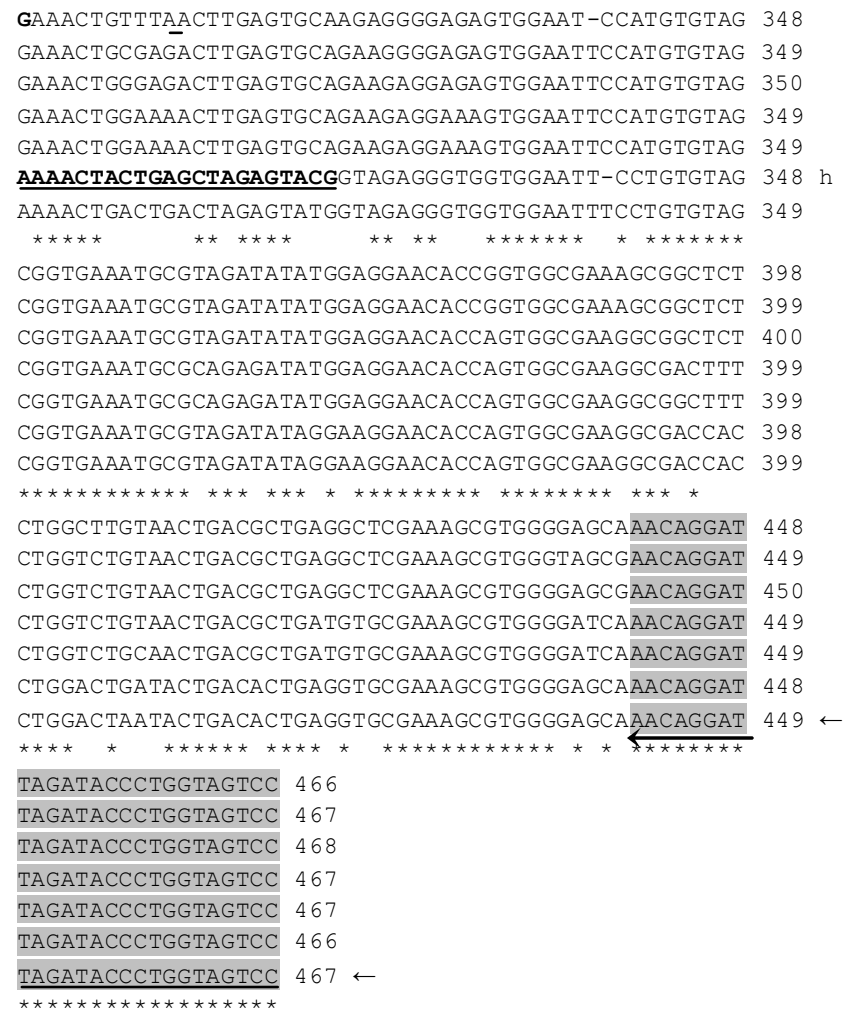

GAAACTGTTTAACTTGAGTGCAAGAGGGGAGAGTGGAAT-CCATGTGTAG 348 GAAACTGCGAGACTTGAGTGCAGAAGGGGAGAGTGGAATTCCATGTGTAG 349 GAAACTGGGAGACTTGAGTGCAGAAGAGGAGAGTGGAATTCCATGTGTAG 350 GAAACTGGAAAACTTGAGTGCAGAAGAGGAAAGTGGAATTCCATGTGTAG 349 GAAACTGGAAAACTTGAGTGCAGAAGAGGAAAGTGGAATTCCATGTGTAG 349 AAAACTACTGAGCTAGAGTACGGTAGAGGGTGGTGGAATT-CCTGTGTAG 348 h AAAACTGACTGACTAGAGTATGGTAGAGGGTGGTGGAATTCCTGTGTAG 349 CGGTGAAATGCGTAGATATATGGAGGAACACCGGTGGCGAAGCGGCTCT 398 CGGTGAAATGCGTAGATATATGGAGGAACACCGGTGGCGAAAGCGGCTCT 399 CGGTGAAATGCGTAGATATATGGAGGAACACCAGTGGCGAAGGCGGCTCT 400 CGGTGAAATGCGCAGAGATATGGAGGAACACCAGTGGCGAAGGCGACTTT 399 CGGTGAAATGCGCAGAGATATGGAGGAACACCAGTGGCGAAGGCGGCTTT 399 CGGTGAAATGCGTAGATATAGGAAGGAACACCAGTGGCGAAGGCGACCAC 398 CGGTGAAATGCGTAGATATAGGAAGGAACACCAGTGGCGAAGGCGACCAC 399 CTGGCTTGTAACTGACGCTGAGGCTCGAAAGCGTGGGGAGCAAACAGGAT 448 CTGGTCTGTAACTGACGCTGAGGCTCGAAAGCGTGGGTAGCGAACAGGAT 449 CTGGTCTGTAACTGACGCTGAGGCTCGAAAGCGTGGGGAGCGAACAGGAT 450 CTGGTCTGTAACTGACGCTGATGTGCGAAAGCGTGGGGATCAAACAGGAT 44 CTGGACTGATACTGACACTGAGGTGCGAAAGCGTGGGGAGCAAACAGGAT 44 CTGGACTAATACTGACACTGAGGTGCGAAAGCGTGGGGAGCAAACAGGAT $449 \leftarrow$ TAGATACCCTGGTAGTCC 466 TAGATACCCTGGTAGTCC 467 TAGATACCCTGGTAGTCC 468 TAGATACCCTGGTAGTCC 467 TAGATACCCTGGTAGTCC 467 TAGATACCCTGGTAGTCC 46

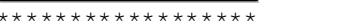

Table 1. Probes designed for use in multiplex PCR

Probe
Pseudomonas spp.
P. aeruginosa
E. coli

Staphylococcus spp.

S. aureus

Enterococcus spp.

Streptococcus spp.

S. pneumoniae
Sequence $\left(5^{\prime}-3^{\prime}\right)^{\mathrm{a}}$

\begin{abstract}
NED-CCTTCCTCCCAACTTAAAGTGCTT-MGB JOE-CCAAAACTACTGAGCTAGAGTACG-BHQ1 JOE-GGAGTAAAGTTAATACCTTTGCTCATT-BHQ1 NED-AATCTTCCGCAATGGGCGAAAGC-MGB FAM-AGATGTGCACAGTTACTTACACATAT-BHQ1 JOE-TCCTTGTTCTTCTCTAACAACAGAG-BHQ1 NED-CCAGAAAGGGACSGCTAACT-MGB JOE-CCAAAGCCTACTATGGTTAAGCCA-BHQ1
\end{abstract}




\section{DNA sequencing}

Samples with discrepant results were further analyzed with sequencing. The DNA was purified using the MSB ${ }^{\circledR}$ PCRapace PCR Cleanup Kit (Invitek, Berlin, Germany) and dissolved in $30 \mu \mathrm{l}$ NASBA $\mathrm{H}_{2} \mathrm{O}$. Cyclic sequencing was performed using BigDye 3.0 (Applied Biosystems, Foster City, California, United States). The resulting sequence product was purified and separated on the 3730 DNA Analyzer (Applied Biosystems, Foster City, California, United States).

\section{Results}

\section{Design of the species or genus-specific probes}

The specificity of the probes was evaluated using BLAST. In silico analysis revealed that nearly only cross-reactivity was found with not clinically relevant microorganisms such as Geobacillus spp. and Lactobacillus plantarum. In silico cross-reactivity with clinically relevant microorganisms was tested in vitro with reference strains. For example, in silico the E. coli probe cross-reacted with Acinetobacter spp. and Enterobacter spp. However, in vitro tests showed no positive signals for these microorganisms. Furthermore, cross-reactions were found with Escherichia albertii and Shigella spp. Based on literature, these microorganisms only occur rarely in blood cultures and therefore the risk of false identification was minimal. In a few cases such as with the Streptococcus spp. and the Staphylococcus spp. probe, cross-reactivity was found with Bacillus cereus. The species conferring cross-reactivity in PCR were then sequenced to check for mismatches between the probe-target hybrids. Sequencing results showed that this occurred because of at least two mismatches at the binding site of both probes (data not shown). However, in all these cases the cross-reacting fluorescent signals generated by the mismatched probes were weak compared to the positive template control and uncharacteristically appeared over 5 cycles later than signals from 100\% matched probes (data not shown).

\section{Evaluation of the multi-probe assay by testing clinical blood culture samples}

From a total of 248 blood cultures, the presence or absence of bacterial DNA was determined in 232 growth-positive and 16 growth-negative samples using the universal probe, yielding a sensitivity and specificity of $100 \%$ (Table 2). 
Table 2. Bacterial isolates in 232 positive blood cultures and results from universal and specific realtime PCR.

\begin{tabular}{|c|c|c|c|c|c|c|c|c|c|}
\hline \multirow[b]{2}{*}{ Pathogen } & \multicolumn{9}{|c|}{ Result of blood culture (no. [\%]) ${ }^{a}$} \\
\hline & uni & pseu & pseuae & ecoli & staph & stau & ente & strept & strepn \\
\hline \multicolumn{10}{|l|}{ Gram-negative pathogens: } \\
\hline Acinetobacter /woffii/haemolyticus & $1(100)$ & 0 & 0 & 0 & - & - & - & - & - \\
\hline Bacteroides fragilis & $2(100)$ & 0 & 0 & 0 & - & - & - & - & - \\
\hline Citrobacter koseri & $1(100)$ & 0 & 0 & 0 & - & - & - & - & - \\
\hline Enterobacter cloacae & $3(100)$ & 0 & 0 & 0 & - & - & - & - & - \\
\hline Escherichia coli & $43(100)$ & 0 & 0 & 43 & - & - & - & - & - \\
\hline Gram-negative rod & $2(100)$ & 0 & 0 & 0 & - & - & - & - & - \\
\hline Klebsiella oxytoca & $5(100)$ & 0 & 0 & 0 & - & - & - & - & - \\
\hline Klebsiella pneumoniae & $7(100)$ & 0 & 0 & 0 & - & - & - & - & - \\
\hline Moraxella catarrhalis & $1(100)$ & 0 & 0 & 0 & - & - & - & - & - \\
\hline Morganella morganii & $1(100)$ & 0 & 0 & 0 & - & - & - & - & - \\
\hline Neisseria meningitidis & $1(100)$ & 0 & 0 & 0 & - & - & - & - & - \\
\hline Prevotella buccae & $1(100)$ & 0 & 0 & 0 & - & - & - & - & - \\
\hline Proteus mirabilis & $2(100)$ & 0 & 0 & 0 & - & - & - & - & - \\
\hline Pseudomonas aeruginosa & $10(100)$ & 10 & 10 & 0 & - & - & - & - & - \\
\hline Pseudomonas oryzihabitans & $1(100)$ & 1 & 0 & 0 & - & - & - & - & - \\
\hline Serratia marcescens & $4(100)$ & 0 & 0 & 0 & - & - & - & - & - \\
\hline \multicolumn{10}{|l|}{ Gram-positive pathogens: } \\
\hline Aerococcus viridans & $1(100)$ & - & - & - & 0 & 0 & 1 & 0 & 0 \\
\hline Coag.-neg.Staphylococcus spp. & $85(100)$ & - & - & - & 85 & 9 & 0 & 0 & 0 \\
\hline Corynebacterium spp. & $2(100)$ & - & - & - & 0 & 0 & 0 & 0 & 0 \\
\hline Enterococcus avium & $1(100)$ & - & - & - & 0 & 0 & 1 & 0 & 0 \\
\hline Enterococcus faecalis & $3(100)$ & - & - & - & 0 & 0 & 3 & 0 & 0 \\
\hline Enterococcus faecium & $4(100)$ & - & - & - & 0 & 0 & 4 & 0 & 0 \\
\hline Lactobacillus spp. & $1(100)$ & - & - & - & 0 & 0 & 0 & 0 & 0 \\
\hline Propionibacterium acnes & $1(100)$ & - & - & - & 0 & 0 & 0 & 0 & 0 \\
\hline Staphylococcus aureus & $31(100)$ & - & - & - & 31 & 31 & 0 & 0 & 0 \\
\hline Streptococcus agalactiae & $1(100)$ & - & - & - & 0 & 0 & 0 & 1 & 0 \\
\hline Streptococcus group A and/or D & $2(100)$ & - & - & - & 0 & 0 & 0 & 2 & 0 \\
\hline Streptococcus milleri & $3(100)$ & - & - & - & 0 & 0 & 0 & 3 & 0 \\
\hline Streptococcus oralis & $1(100)$ & - & - & - & 0 & 0 & 0 & 1 & 0 \\
\hline Streptococcus pneumoniae & $6(100)$ & - & - & - & 0 & 0 & 0 & 6 & 6 \\
\hline Streptococcus pyogenes & $1(100)$ & - & - & - & 0 & 0 & 0 & 1 & 0 \\
\hline Streptococcus sanguis & $1(100)$ & - & - & - & 0 & 0 & 0 & 1 & 0 \\
\hline \multicolumn{10}{|l|}{ Mixed: } \\
\hline \multicolumn{10}{|l|}{ Alcaligenes faecalis, } \\
\hline $\begin{array}{l}\text { Propionibacterium spp. } \\
\text { Klebsiella oxytoca, Serratia }\end{array}$ & $1(100)$ & 0 & 0 & 0 & 0 & 0 & 0 & 0 & 0 \\
\hline marcescens & $1(100)$ & 0 & 0 & 0 & - & - & - & - & - \\
\hline \multicolumn{10}{|l|}{ Streptococcus salivarius, } \\
\hline Streptococcus viridans & $1(100)$ & - & - & - & 0 & 0 & 0 & 1 & 0 \\
\hline \multicolumn{10}{|l|}{ Totals: } \\
\hline Concordant & & 11 & 10 & 43 & 116 & 31 & 8 & 16 & 6 \\
\hline Discordant & & 0 & 0 & 0 & 0 & 9 & 1 & 0 & 0 \\
\hline
\end{tabular}

ani, universal probe; pseu, Pseudomonas spp.; pseuae, P. aeruginosa; ecoli, E. coli; staph, Staphylococcus spp.; stau, S. aureus; ente, Enterococcus spp.; strept, Streptococcus spp.; strepn, S. pneumoniae 
Our multi-probe assay was performed after Gram-staining of the positive blood cultures. Considering the growth-positive blood cultures, results from the multiprobe assay were in accordance with conventional identification in $222(96 \%)$ cases. The specific probes targeting Pseudomonas spp., P. aeruginosa, E. coli, Streptococcus spp., S. pneumoniae, and Staphylococcus spp. all had a sensitivity and specificity of $100 \%$. The majority, 85 of 145 (59\%) Gram-positive blood cultures contained a CoNS. In thirty-one blood cultures, the causative agent was identified as $S$. aureus. Regarding the Gram-positive staphylococcal blood cultures, the multi-probe assay was in conflict with culture results in nine cases. The nine discrepancies were further analyzed by coagulase testing, specific $S$. aureus real-time PCR, and sequencing (Table 3, Figure 2). One out of nine cases, clinical isolate $(\mathrm{Cl}) 7$, was tested coagulase-positive, and was positive for two targets specific for $S$. aureus, i.e. femA and sa442. Sequencing of the PCR product also confirmed the results of the multi-probe assay. The sequences of the eight other clinical isolates showed three mismatches compared with the reference $S$. aureus sequence, as shown in Figure $2 \mathrm{~A}$. Hence, the remaining eight cases were confirmed as discordant. Consequently, a sensitivity and specificity of $100 \%$ and $93 \%$, respectively, and a positive and negative predictive value of $79 \%$ and $100 \%$, respectively was achieved when sequencing was considered as gold standard. The probe specific for Enterococcus spp. showed one conflicting result. One blood culture was determined to contain an Aerococcus viridans, while our multi-probe assay identified the infectious agent as Enterococcus spp. (Table 3).

Table 3. Clinical isolates with discordant blood culture and PCR results

\begin{tabular}{|c|c|c|c|c|}
\hline Blood culture & Specific probes ${ }^{D}$ & femA, sa442 ${ }^{c}$ & $\begin{array}{l}\text { Coagulase } \\
\text { activity }\end{array}$ & Sequence \\
\hline $\mathrm{Cl}^{\mathrm{a}}$ 1: CoNS & staph, stau & $\mathrm{N}-\mathrm{N}$ & $\mathrm{N}$ & Unidentified \\
\hline Cl 2: CoNS & staph, stau & $\mathrm{N}-\mathrm{N}$ & $\mathrm{N}$ & S. hominis \\
\hline Cl 3: CoNS & staph, stau & $\mathrm{N}-\mathrm{N}$ & $\mathrm{N}$ & S. hominis \\
\hline Cl 4: CoNS & staph, stau & $\mathrm{N}-\mathrm{N}$ & $\mathrm{N}$ & S. pasteuri \\
\hline CI 5: CoNS & staph, stau & $\mathrm{N}-\mathrm{N}$ & $\mathrm{N}$ & S. hominis \\
\hline Cl 6: CoNS & staph, stau & $\mathrm{N}-\mathrm{N}$ & $\mathrm{N}$ & S. schleiferi \\
\hline Cl 7: CoNS & staph, stau & P-P & $\mathrm{P}$ & S. aureus \\
\hline Cl 8: CoNS & staph, stau & $\mathrm{N}-\mathrm{N}$ & $\mathrm{N}$ & S. pasteuri \\
\hline Cl 9: CoNS & staph, stau & $\mathrm{N}-\mathrm{N}$ & $\mathrm{N}$ & S. epidermidis \\
\hline Cl 10: A. viridans & ente & n.a. & n.a. & Enterococcus spp. \\
\hline
\end{tabular}

\footnotetext{
${ }^{\mathrm{a}} \mathrm{Cl}$, clinical isolate

${ }^{\text {b }}$ staph, Staphylococcus spp. ; stau, S. aureus ; ente, Enterococcus spp.

${ }^{\mathrm{C}} \mathrm{N}$, negative ; $\mathrm{P}$, positive; n.a., not applicable
}

Further analysis revealed that the partial sequence of $\mathrm{Cl} 10$ was completely similar to the sequence of a reference Enterococcus spp. strain, as shown in Figure 2B. Comparison of reference $A$. viridans and Enterococcus spp. strains 68 
showed five mismatches. Consequently, the probe specific for Enterococcus spp. yielded a sensitivity and specificity of $100 \%$ when sequencing was considered as gold standard.

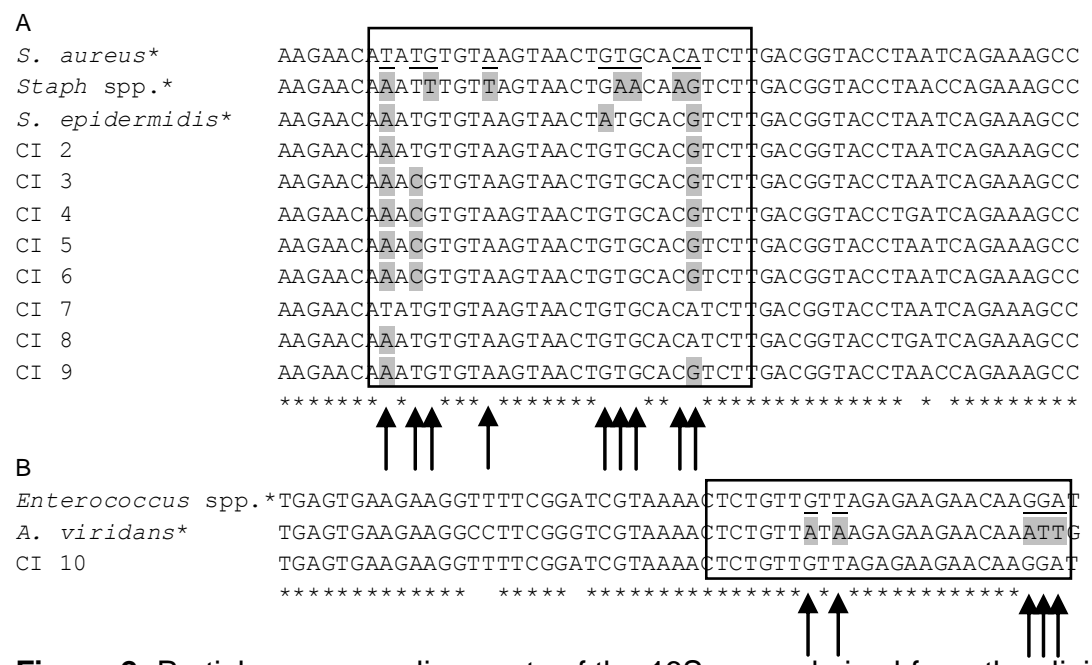

Figure 2. Partial sequence alignments of the $16 \mathrm{~S}$ gene, derived from the clinical isolates with discordant results. A) i.e. region where the probe specific for $S$. aureus binds. The sequences of the eight discrepancies are shown in the rectangle. The nucleotides underlined in the rectangle represent the nucleotides which distinguish a $S$. aureus from a Staphylococcus spp. The sequence alignment of clinical isolate $(\mathrm{Cl}) 7$ is the exact reverse complement of the $S$. aureus probe sequence, which implicates that this isolate, which was identified as CoNS, is in fact a $S$. aureus. $\mathrm{Cl} 1$ was not shown because the sequence could not be determined. Accession numbers reference strains: $S$. aureus FN433596, Staphylococcus spp. GQ222246, S. epidermidis GQ911565. B) i.e. region where the probe specific for Enterococcus spp. binds. The nucleotides underlined in the rectangle represent the nucleotides which distinguish an Enterococcus spp. from an $A$. viridans. Conventional testing identified $\mathrm{Cl} 9$ as Aerococcus viridans, whereas our assay and sequencing classified it as Enterococcus spp. Accession numbers reference strains: Enterococcus spp. AB489105, A. viridans M58797. *, reference sequences; Cl, clinical isolate; CoNS, coagulase-negative Staphylococcus spp.

\section{Discussion}

New strategies for the detection and identification of bacterial pathogens in blood are continuously under investigation worldwide. Current diagnostic tools are hampered by several factors such as a lack of sensitivity and a long time-toresults, the presence of PCR inhibitory compounds in certain sample materials, and the occurrence of fastidious and non-culturable microorganisms. Rapid universal 16S rDNA gene-based PCR is often combined with sequence analysis, and a considerable number of commercial assays have been 
generated and tested recently, i.e. SeptiFast (Roche Diagnostics, Mannheim, Germany), Prove-itSepsis (Mobidiag, Helsinki, Finland), and SeptiTest (MolZym, Bremen, Germany). The latter includes a universal 16S rDNA genebased PCR assay combined with sequence analysis, while the two other commercial assays use a panel of probes for the detection of a range of bacterial and mycotic pathogens. Virtually all studies conducted with the SeptiFast and SeptiTest assays found similar results, i.e. an overall agreement of $77-83 \% \%^{5,10-15}$. Both assays are validated for whole blood samples and can be completed in four to six hours. Tissari et al. performed an observational study comparing conventional culture with Prove-it ${ }^{\mathrm{TM}}$ Sepsis. The assay, based on a microarray platform and performed on blood cultures, had a clinical sensitivity of $94.7 \%$ and a specificity of $98.8 \%{ }^{16}$.

In our study, the 16S rDNA gene was used for the design of eight species or genus-specific probes. The sequence similarities found in in silico analysis (BLAST) were mainly derived from not clinically relevant microorganisms such as Geobacillus spp., Paenibacillus spp., L. plantarum, and L. fermentum. Remaining similarities were, if available, tested in vitro with reference strains. A limited number of microorganisms showed cross-reactivity. For example, streptococcal and staphylococcal probes weakly cross-reacted with $B$. cereus. In these cases, sequencing determined the correct identification. Additionally, as the assay is always preceded by Gram-staining, in most cases morphology data from Gram-staining was in contradiction with these false-positive signals and targeted the samples for confirmatory sequencing.

Our multi-probe assay was designed for use on blood culture material and can be completed within two hours. Use of whole blood samples could significantly improve the turnaround time of our assay. However, since culturing still remains essential to determine the micro-organisms antimicrobial profile, we chose to use blood cultures instead of whole blood. In this study, we found an overall agreement of $97 \%$ between conventional testing and our multi-probe assay. One of the strengths of our approach is that the assay can be extended by adding more probes for other bacterial pathogens to the identification panel. The grouping of Gram-negative and Gram-positive bacteria was based on the identifications needed for antimicrobial susceptibility testing. The assay was designed to use a universal probe for detection, instead of SYBR Green, because it is known that SYBR Green can generate false-positive signals because of the presence of background human DNA or the formation of primerdimers.

Analysis of the conflicting results showed that in some cases our assay was in accordance with sequencing results. The reference sequence derived from a Staphylococcus spp. and a $S$. epidermidis strain showed seven and three mismatches, respectively, compared with the reference sequence derived from a $S$. aureus strain. The sequences derived from the discrepant clinical isolates 
only showed three or less mismatches compared with the $S$. aureus sequence. This indicated that within the group of staphylococci more homologous sequences can cause false-positives because of the less efficient binding capacity of the $S$. aureus-specific probe.

Overall, these results showed a strong agreement between conventional testing and our novel, real-time PCR assay. Furthermore, this assay significantly reduced the time needed for identification in comparison to routine diagnostics. In conclusion, using pathogen-specific probes offers a faster alternative for pathogen detection and could improve the diagnosis of bloodstream infections. The assay will be implemented in a clinical trial investigating the impact of earlier pathogen identification in combination with susceptibility testing on the choice of therapy.

\section{References}

1. Wallet $F$, Nseir $S$, Baumann $L$ et al. Preliminary clinical study using a multiplex real-time PCR test for the detection of bacterial and fungal DNA directly in blood. Clin Microbiol Infect 2009.

2. Peters RP, van Agtmael MA, Danner SA et al. New developments in the diagnosis of bloodstream infections. Lancet Infect Dis 2004; 4: 751-60.

3. Beekmann SE, Diekema DJ, Chapin KC et al. Effects of rapid detection of bloodstream infections on length of hospitalization and hospital charges. J Clin Microbiol 2003; 41: 3119-25.

4. Hansen WL, Bruggeman CA, Wolffs PF. Evaluation of new preanalysis sample treatment tools and DNA isolation protocols to improve bacterial pathogen detection in whole blood. J Clin Microbiol 2009; 47: 2629-31.

5. Wellinghausen N, Kochem AJ, Disque $C$ et al. Diagnosis of bacteremia in whole-blood samples by use of a commercial universal 16S rRNA gene-based PCR and sequence analysis. J Clin Microbiol 2009; 47: 2759-65.

6. Duan QJ, Shang SQ, Wu YD. Rapid diagnosis of bacterial meningitis in children with fluorescence quantitative polymerase chain reaction amplification in the bacterial $16 \mathrm{~S}$ rRNA gene. Eur J Pediatr 2009; 168: 211-6.

7. Qian Q, Tang YW, Kolbert CP et al. Direct identification of bacteria from positive blood cultures by amplification and sequencing of the 16S rRNA gene: evaluation of BACTEC 9240 instrument true-positive and false-positive results. J Clin Microbiol 2001; 39: 357882.

8. Mignard S, Flandrois JP. 16S rRNA sequencing in routine bacterial identification: a 30month experiment. J Microbiol Methods 2006; 67: 574-81.

9. Nadkarni MA, Martin FE, Jacques NA et al. Determination of bacterial load by real-time PCR using a broad-range (universal) probe and primers set. Microbiology 2002; 148: 25766.

10. Westh HOURS, Lisby G, Breysse F et al. Multiplex real-time PCR and blood culture for identification of bloodstream pathogens in patients with suspected sepsis. Clin Microbiol Infect 2009; 15: 544-51.

11. Dierkes $C$, Ehrenstein B, Siebig $S$ et al. Clinical impact of a commercially available multiplex PCR system for rapid detection of pathogens in patients with presumed sepsis. BMC Infect Dis 2009; 9: 126.

12. Varani $S$, Stanzani $M$, Paolucci $M$ et al. Diagnosis of bloodstream infections in immunocompromised patients by real-time PCR. J Infect 2009; 58: 346-51. 


\section{CHAPTER 3a}

13. Mancini N, Clerici D, Diotti R et al. Molecular diagnosis of sepsis in neutropenic patients with haematological malignancies. J Med Microbiol 2008; 57: 601-4.

14. Casalta JP, Gouriet F, Roux V et al. Evaluation of the LightCycler SeptiFast test in the rapid etiologic diagnostic of infectious endocarditis. Eur J Clin Microbiol Infect Dis 2009; 28: 569-73.

15. von Lilienfeld-Toal M, Lehmann LE, Raadts $A D$ et al. Utility of a commercially available multiplex real-time PCR assay to detect bacterial and fungal pathogens in febrile neutropenia. J Clin Microbiol 2009; 47: 2405-10.

16. Tissari $P$, Zumla A, Tarkka $E$ et al. Accurate and rapid identification of bacterial species from positive blood cultures with a DNA-based microarray platform: an observational study. Lancet; 375: 224-30. 




\section{Chapter 3b}

\section{Rapid identification of Candida species in blood cultures by multiprobe TaqMan PCR assay}

Özlem Güven, Wendy L. J. Hansen, Astrid Oude Lashof, Frank van Tiel, Cathrien A. Bruggeman, Petra F. G. Wolffs

Manuscript in preparation 


\section{Abstract}

We report a multiprobe TaqMan PCR assay for detection and differentiation of four clinically relevant Candida species in blood culture samples. We developed and evaluated species specific probes which were used in conjunction with a universal Candida probe. All probes targeted the internal transcribed spacer regions and for identification of Candida albicans, Candida parapsilosis, Candida glabrata and Candida krusei in two reaction tubes in a single run of real time PCR. The assay can give results in three hours after detection of yeast cells in positive blood culture by Gram staining. DNA detection limits of the assay for C. albicans, C. parapsilosis, C. glabrata and C. krusei were 15, 50, 350 and 5 colony-forming units (cfu) per $\mathrm{ml}$, respectively. 


\section{Introduction}

There is an increasing patient population at high risk of acquiring opportunistic infections due to a.o. the use of immunosuppressive therapy. Within these immunocompromised patients, invasive fungal infections (IFIs) are more and more recognized as an important cause of morbidity and mortality ${ }^{1}$. Among the fungi the most common causative agents of opportunistic infections are Candida species and invasive infections with Candida species have significant mortality rates between 38 to $74 \%{ }^{2}$. Although Candida albicans remains the leading pathogen of IFIs and is the most commonly found Candida species in blood cultures, there are many reports that point out the increase in incidence of non-albicans Candida species such as Candida glabrata and Candida parapsilosis $^{3-5}$. Infections with non-albicans Candida species are important because of their resistance profiles to antifungal agents. C. glabrata and Candida krusei have reduced susceptibility to azoles which are the most frequently used antifungal agents in clinical practice. C. parapsilosis displays decreased susceptibility to echinocandins. Thus, rapid and accurate identification of fungal species guides the early initiation of appropriate antifungal therapy and is therefore of crucial importance for patient outcome ${ }^{6}$.

Blood culture is accepted as a gold standard for diagnosis of IFIs. Identification of Candida species in positive blood cultures with conventional biochemical and phenotypic methods requires commonly two or three days. Therefore, the availability of a rapid test for identification of Candida spp., more specifically $C$. glabrata and $C$. krusei could prevent delays in the administration of appropriate therapy ${ }^{7},{ }^{8}$. In recent years, different molecular approaches have been developed for rapid identification of Candida species from blood or blood cultures $^{8-10}$. However, most assays identified only a limited number of Candida species and/or did not include pan-Candida or panfungal primers or probes to detect those species not specifically targeted.

The aim of our study was development of a rapid assay for identification of four clinically relevant Candida species in conjunction with a universal Candida probe detecting all commonly found Candida species. The assay is intended to be used on positive blood culture samples after the detection of yeast cells by Gram-staining.

\section{Materials and Methods}

\section{Yeast Strains and Clinical Samples}

Clinical fungal isolates collected at the Department of Medical Microbiology of Maastricht University Medical Center (MUMC+, Maastricht, The Netherlands) were cultivated on Sabouraud dextrose agar for 48 hours at $30^{\circ} \mathrm{C}$. Dilutions of 
yeast cells were prepared with sterile saline suspensions that were adjusted to match that of a $0.5 \mathrm{McF}$ arland standard. Blood culture samples for spiking experiments were obtained from negative blood culture bottles. Whereas for the pilot study blood culture bottles (BACTEC Peds Plus ${ }^{T M}$, BD Diagnostic Systems) were incubated and monitored for microbial growth in the Bactec 9240 automated blood culture device (BD Diagnostic Systems). Standard conventional testing was performed for fungal identification. All clinical samples were anonymized and treated according to the code for proper use of human tissue as formulated by the Dutch Federation of Medical Scientific Societies.

\section{DNA Extraction}

A total of $200 \mu \mathrm{l}$ of blood culture sample was washed twice by adding it to $1 \mathrm{ml}$ of sterile demineralized water, and centrifuging it at $13,000 \times \mathrm{g}$ for $2 \mathrm{~min}$. The pellet was resuspended in $500 \mu \mathrm{l}$ of lyticase solution (50 U/ml lyticase (Sigma Aldrich, St. Louis, MO, USA), $50 \mathrm{mM}$ Tris [pH 7.5], $10 \mathrm{mM}$ EDTA, $28 \mathrm{mM} \beta$ mercaptoethanol) and incubated $37^{\circ} \mathrm{C}$ for $30 \mathrm{~min}$ to produce spheroplasts. After centrifugation, QIAamp DNA Mini kit (Qiagen, Hilden, Germany) was used and the pellet was suspended in $180 \mu \mathrm{l}$ Buffer ATL and $20 \mu \mathrm{l}$ proteinase $\mathrm{K}$ and incubated at $56^{\circ} \mathrm{C}$ for $15 \mathrm{~min}$ with occasional vortexing. After incubation $200 \mu \mathrm{l}$ Buffer AL (provided in the QIAamp DNA mini kit) was added and incubated at $70^{\circ} \mathrm{C}$ for $10 \mathrm{~min}$. A total of $600 \mu \mathrm{l}$ water was added followed by $800 \mu \mathrm{l}>99 \%$ benzyl alcohol (Merck) and vortexed. In order to separate the phases, the sample was centrifuged at $20,000 \times \mathrm{g}$ for $5 \mathrm{~min}$ and $200 \mu \mathrm{l}$ of supernatant was transferred to a QIAamp Mini spin column. The column was centrifuged at 6,000 $\mathrm{xg}$ for $1 \mathrm{~min}$. A $500 \mu \mathrm{l}$ of AW1 buffer was added, and incubation of $5 \mathrm{~min}$ at room temperature was followed by centrifugation at $6,000 \times \mathrm{g}$ for $1 \mathrm{~min}$. The spin column was placed into a new collection tube, and $500 \mu \mathrm{l}$ of AW2 buffer was added and centrifuged at 20,000 $\mathrm{g}$ for $3 \mathrm{~min}$. The spin column was placed into a new collection tube and centrifuged at $20,000 \times \mathrm{g}$ for $1 \mathrm{~min}$ as recommended in manufacturer's protocol. The DNA was extracted from the spin with adding $50 \mu \mathrm{l}$ of $\mathrm{AE}$ buffer. The column was incubated at room temperature for $1 \mathrm{~min}$ and centrifuged at $6,000 \mathrm{xg}$ for $1 \mathrm{~min}$.

\section{Primer and TaqMan Probe Design}

The universal amplification primers ITS1, ITS2, ITS3 ${ }^{11}$ and ITS4-rev (designed for this study) were used to amplify ITS regions of rDNA. Uni-Candida probe designed by Shin et al. ${ }^{12}$ was used as a Candida genus-specific probe (Table 1). The real-time PCR primer and probes were designed based on in silico analysis of the ITS region using BLAST(http://www.ncbi.nlm.nih.gov/BLAST). To find the most conserved regions the sequences were aligned using ClustalW2 
software. The sequences of primers and probes were checked for crossreactions by using the BLAST algorithm. Oligonucleotides with the reporter dyes FAM and JOE were synthesized by Sigma Aldrich, NED-labeled probes were obtained from Applied Biosystems (Foster City, CA, USA).

\section{PCR Conditions}

To determine the optimal primer and probe concentrations primer and probe matrices were performed. For each sample, two multiprobe reaction mixtures were used. One of PCR mixtures consisted of 2x Qiagen Multiplex PCR Master Mix (Qiagen, Hilden, Germany), $300 \mathrm{nM}$ concentration of ITS1 and ITS2 primers, $250 \mathrm{nM} \mathrm{C.} \mathrm{glabrata} \mathrm{probe,} 250 \mathrm{nM}$ C. parapsilosis probe and $100 \mathrm{nM}$ C. krusei probe. The other PCR mixture consisted of $2 \times$ QIAGEN Multiplex PCR Master Mix, $300 \mathrm{nM}$ concentration of ITS3 and ITS4-rev primers, $250 \mathrm{nM}$ UniCandida probe and $100 \mathrm{nM} \mathrm{C.} \mathrm{albicans} \mathrm{probe.} \mathrm{DNA} \mathrm{samples} \mathrm{were} \mathrm{analyzed} \mathrm{by}$ using the 7900HT Fast Real-Time PCR System (Applied Biosystems, Foster City, CA) according to the following cycling parameters: $2 \mathrm{~min}$ at $50^{\circ} \mathrm{C}, 15 \mathrm{~min}$ at $95^{\circ} \mathrm{C}$ followed by 45 cycles of $15 \mathrm{~s}$ at $95^{\circ} \mathrm{C}$ and $1 \mathrm{~min}$ at $60^{\circ} \mathrm{C}$.

Table 1. Primers and probes used for detection and identification of Candida species in two reaction mixtures.

\begin{tabular}{lll}
\hline Primer/Probe & Sequence & Reference \\
\hline ITS1 & 5'-TCCGTAGGTGAACCTGCGG-3' & 11 \\
ITS2 & 5'-GCTGCGTTCTTCATCGATGC-3' & 11 \\
C. glabrata & 5'-JOE-TGTCTGAGCTCGGAGAGAGACATC-BHQ1-3' & This study \\
C. krusei & 5'-NED-CACTGCGTGAGCGGAACGAAAACA-MGB-NFQ-3' & This study \\
C. parapsilosis & 5'-FAM-TTGGTAGGCCTTCTATATGGGGCCT-BHQ1-3' & This study \\
ITS3 & 5'-GCATCGATGAAGAACGCAGC-3' & 11 \\
ITS4-rev & 5'-TATGCTTAAGTTCAGCGGGT-3' & This study \\
Uni-Candida & 5'-JOE-AGGGCATGCCTGTTTGAGCGTC-BHQ1-3' & 12 \\
C. albicans & 5'-NED-CATTGTCAAAGCGATCCCGCCTTA-MGB-NFQ-3' & This study \\
\hline
\end{tabular}

\section{Assay evaluation}

The lower limit of detection (LOD) for each Candida species was determined by using negative blood culture samples spiked with serially diluted yeast cell suspensions to the final concentrations of $10^{6}$ to $10^{0} \mathrm{cfu} / \mathrm{ml}$. Candida concentrations were determined by plating $100 \mu \mathrm{l}$ of the diluted sample onto Sabouraud dextrose agar plate. The probes were evaluated for possible cross- 
reactivity in vitro against blood culture samples spiked with various microorganisms, i.e. Candida tropicalis, Candida lusitanae, Candida dubliniensis and Candida guillermondii as well as Saccharomyces cerevisiae, Cryptococcus neoformans, Trichosporon spp., Verticillium spp., Aspergillus fumigatus and the bacteria Staphylococcus aureus, Escherichia coli, Pseudomonas aeruginosa, Klebsiella pneumoniae and Streptococcus spp.

\section{Results}

Results showed that there was no cross-reactivity between the species-specific probes of our multiprobe assay nor with $C$. tropicalis, $C$. lusitanae, $C$. dubliniensis and $C$. guillermondii. In addition, we also observed no false-positive results with the following various fungi, i.e. Trichosporon spp., S. cerevisiae and $C$. neoformans, as well with the following bacteria which are frequently found in blood cultures, i.e. coagulase-negative staphylococci (CoNS), S. aureus, P. aeruginosa, E. coli, Klebsiella spp. and Streptococcus spp. However, we did observe cross-reactivity of the universal Candida probe with other fungi, i.e. Verticillium spp., S. cerevisiae and C. neoformans.

The assay was combined with an optimized protocol for DNA extraction of Candida species from blood culture material. The optimized DNA extraction protocol included modifications on the enzymatic lysis method of the QIAamp DNA Mini kit (Qiagen, Hilden, Germany) procedure and added a phase separation step with benzyl alcohol which allowed us to overcome PCR inhibitors. The complete assay including DNA isolation and multiprobe assay was evaluated using negative blood cultures spiked with grown Candida species. The results showed that the limits of detection for $C$. albicans, $C$. parapsilosis, C. glabrata and C. krusei were 15, 50, 350 and $5 \mathrm{cfu} / \mathrm{ml}$, respectively. We found no differences between the samples obtained from aerobic, anaerobic and pediatric bottles with similar inoculums (data not shown).

Finally, in a pilot experiment, five sets of blood cultures in which fungal cells were detected by Gram-staining, were tested by the new assay. Conventional culturing identified one set to be containing Trichosporon spp., three sets containing C. albicans and one set containing C. glabrata. All positive Candida cultures were correctly identified, showing both positive signals by the universal Candida probe as well as the respective species probe. All real-time PCR signals had $\mathrm{Ct}$ values between 18 and 25 by the respective probes. The cultures containing Trichosporon spp. correctly showed no positive signal. From one of the sets containing $C$. albicans, additional blood culture bottles from four days earlier were available. All four of these blood culture bottles had remained culture-negative. Upon testing, three out of four bottles showed positive PCR results for $C$. albicans with high $C t$ values between 33 and 38 . 


\section{Discussion}

In this study, we developed and evaluated a multiprobe assay including a universal Candida probe and four species-specific probes for the rapid identification of Candida species from blood cultures. The first step of the complete assay consisted of an optimized DNA isolation protocol which included enhanced enzymatic lysis and a phase separation step with benzyl alcohol to overcome PCR inhibitors. Blood culture media contains several PCR inhibitors, and one of them is sodium polyanethol sulfonate (SPS). Therefore, several studies included benzyl alcohol separations for the removal of PCR inhibitors from blood culture media ${ }^{13,14}$.

The design of the multiprobe real-time PCR assay included four speciesspecific probes for the detection of $C$. albicans, C. parapsilosis, C. glabrata and $C$. krusei. While our species-specific probes showed no cross-reactivity with DNA templates isolated from a panel of bacterial and fungal species, the uniCandida probe cross-hybridized with DNA of several other fungal species. Therefore, in our setup a positive signal obtained from the Uni-Candida probe alone may not be interpreted as the presence of Candida species and should be further evaluated by using DNA sequencing. The analytical sensitivity of the complete multiprobe assay differed per species between 350 and $5 \mathrm{cfu} / \mathrm{ml}$. This is in the same range or slightly higher than other published Candida real-time PCR assay data ${ }^{15,16}$. However, in our study we used aliquots of negative blood culture bottles spiked with yeast cells in contrast to fresh whole blood samples used in most other studies. Our higher detection limits may be related with the presence of inhibitors from blood culture media. Our results presenting low $\mathrm{Ct}$ values between 18 and 25 in positive blood cultures showed that the analytical sensitivity of the assay when used on blood cultures is more than sufficient. However, in analogy with earlier work on positive blood cultures containing bacteria, utilizing the assay's sensitivity to its full capacity could decrease the time that is needed for incubation of blood cultures ${ }^{17}$. Future (prospective) studies on clinical samples will have to be performed to establish the clinical sensitivity and specificity as well as to indicate the potential for use on other clinical materials.

In conclusion, the novel multiprobe assay detects Candida species and identifies $C$. albicans, C. parapsilosis, C. glabrata and $C$. krusei in two reaction tubes in a single run and it provides results in three hours after detection of yeast cells by Gram staining of positively flagged blood culture samples. Therefore, this assay allows rapid identification of Candida species and may provide an opportunity to start appropriate antifungal treatment in a timely manner in patients with candidemia. 


\section{References}

1. Shoham S, Marwaha S. Invasive fungal infections in the ICU. J Intensive Care Med 2010; 25: 78-92.

2. Chen SC, Halliday CL, Meyer W. A review of nucleic acid-based diagnostic tests for systemic mycoses with an emphasis on polymerase chain reaction-based assays. Med Mycol 2002; 40: 333-57.

3. Arendrup MC. Epidemiology of invasive candidiasis. Curr Opin Crit Care 2010; 16: 44552.

4. Pfaller MA, Moet GJ, Messer SA et al. Candida bloodstream infections: comparison of species distributions and antifungal resistance patterns in community-onset and nosocomial isolates in the SENTRY Antimicrobial Surveillance Program, 2008-2009. Antimicrob Agents Chemother 2011; 55: 561-6.

5. Sobel JD. Changing trends in the epidemiology of Candida blood stream infections: a matter for concern? Crit Care Med 2010; 38: 990-2.

6. Labelle AJ, Micek ST, Roubinian $\mathrm{N}$ et al. Treatment-related risk factors for hospital mortality in Candida bloodstream infections. Crit Care Med 2008; 36: 2967-72.

7. Bellemain E, Carlsen T, Brochmann $C$ et al. ITS as an environmental DNA barcode for fungi: an in silico approach reveals potential PCR biases. BMC Microbiol 2010; 10: 189.

8. Metwally L, Hogg G, Coyle PV et al. Rapid differentiation between fluconazole-sensitive and -resistant species of Candida directly from positive blood-culture bottles by real-time PCR. J Med Microbiol 2007; 56: 964-70.

9. Jordanides NE, Allan EK, McLintock LA et al. A prospective study of real-time panfungal $\mathrm{PCR}$ for the early diagnosis of invasive fungal infection in haemato-oncology patients. Bone Marrow Transplant 2005; 35: 389-95.

10. Bile J. New nonculture-based methods for the diagnosis of invasive candidiasis. Curr Opin Crit Care 2010; 16: 460-4.

11. White $\mathrm{T}$, Bruns $\mathrm{T}$, Lee $\mathrm{S}$ et al. Amplification and direct sequencing of fungal ribosomal RNA genes for phylogenetics. PCR protocols: A guide to methods and applications: Academic Press, Inc., 1990; 315-22.

12. Shin JH, Nolte FS, Holloway BP et al. Rapid identification of up to three Candida species in a single reaction tube by a $5^{\prime}$ exonuclease assay using fluorescent DNA probes. $J$ Clin Microbiol 1999; 37: 165-70.

13. Fredricks DN, Relman DA. Improved amplification of microbial DNA from blood cultures by removal of the PCR inhibitor sodium polyanetholesulfonate. J Clin Microbiol 1998; 36: 2810-6.

14. Villumsen S, Pedersen R, Krogfelt KA et al. Expanding the diagnostic use of PCR in leptospirosis: improved method for DNA extraction from blood cultures. PLoS One 2010; 5: e12095.

15. Carvalho A, Costa-De-Oliveira S, Martins ML et al. Multiplex PCR identification of eight clinically relevant Candida species. Med Mycol 2007; 45: 619-27.

16. Maaroufi Y, Heymans C, De Bruyne JM et al. Rapid detection of Candida albicans in clinical blood samples by using a TaqMan-based PCR assay. J Clin Microbiol 2003; 41: 3293-8.

17. Loonen AJ, Jansz AR, Kreeftenberg HOURS et al. Acceleration of the direct identification of Staphylococcus aureus versus coagulase-negative staphylococci from blood culture material: a comparison of six bacterial DNA extraction methods. Eur J Clin Microbiol Infect Dis 2011; 30: 337-42. 




\section{Chapter 4}

\section{A real-time PCR-based semi- quantitative breakpoint to aid in molecular identification of urinary tract infections}

Wendy L. J. Hansen, Christina F. M. van der Donk, Cathrien A. Bruggeman, Ellen E. Stobberingh, Petra F. G. Wolffs 


\section{Abstract}

This study presents a novel approach to aid in diagnosis of urinary tract infections (UTIs). A real-time PCR assay was used to screen for culture-positive urinary specimens and to identify the causative uropathogen. Semi-quantitative breakpoints were used to screen for significant bacteriuria (presence of $\geq 10^{5}$ $\mathrm{cfu} / \mathrm{ml}$ of uropathogens) or low-level bacteriuria (containing between $10^{3}$ and $10^{4} \mathrm{cfu} / \mathrm{ml}$ of uropathogens). The $16 \mathrm{~S}$ rDNA-based assay could identify the most prevalent uropathogens using probes for Escherichia coli, Pseudomonas spp., Pseudomonas aeruginosa, Staphylococcus spp., Staphylococcus aureus, Enterococcus spp. and Streptococcus spp. In total, 225 urinary specimens were analysed and results were compared with conventional urine culture. Using a PCR cycle threshold (Ct) value of 25 as semi-quantitative breakpoint for significant bacteriuria resulted in a sensitivity and specificity of $97 \%$ and $75 \%$, respectively. In $78 \%$ of the samples with monomicrobial infections the assay contained probes to detect the bacteria present in the urine specimens and $98 \%$ of these uropathogens was correctly identified. Concluding, the novel presented approach can distinguish low-level and significant bacteriuria as well as detect the involved uropathogen within four hours after sampling, allowing adequate therapy decisions within the same day as well as drastically reduce consequent urine culturing. 


\section{Introduction}

Molecular techniques are becoming an integral part of a diagnostic microbiological laboratory. Many microbiological laboratories performing realtime PCR already offer a broad panel of bacterial and viral targets. Though, for some infections conventional testing procedures are still being used. Urinary tract infections (UTIs) comprise one of the largest classes of infections occurring both in hospital and in community ${ }^{1-3}$. The diagnosis of UTIs is based on semi-quantitative urine culture, used as reference standard, which provides both quantification as well as identification of the uropathogen. Quantification of uropathogens is essential as different bacterial loads $\left(>10^{3}\right.$ or $\left.10^{5} \mathrm{cfu} / \mathrm{ml}\right)$ are used in combination with clinical symptoms to identify UTIs in different population groups ${ }^{4}$. Obtaining results from a semi-quantitative culture requires at least 18 to 24 hours. In addition, previous studies have shown that depending on the population, up to $80 \%$ of urine cultures are negative, underlining the need for new, less time-consuming and labour-intensive methods ${ }^{3,5-7}$.

To increase the rapidity of identification of UTIs, rapid urinalysis tools are available and include for example testing for nitrite and leukocytes, and microscopic sediment analysis for bacteria and white blood cells. These screening tools are fast, but often lack sensitivity ${ }^{8,9}$. Not all bacteria are capable of converting nitrate into nitrite, resulting in a false-negative test result. Particularly, Pseudomonas aeruginosa and Gram-positive uropathogens such as Staphylococcus saprophyticus and enterococci do not present this bacterial metabolism $^{10,11}$. Reports associated the nitrite test with a sensitivity and specificity of $45-60 \%$ and $85-98 \%$, respectively, leukocyte-esterase testing has been shown to have sensitivity and specificity rates of $48-86 \%$ and $17-93 \%$, respectively ${ }^{8}$. The rapidity and ease of use of urine dipsticks are particularly preferred by general practitioners, whereas microbiological laboratories demand solutions designed for high-throughput analysis. In addition, within hospital settings with generally more complicated UTI's in different risk groups, a disadvantage of the dipstick testing is that the test cannot be adjusted to detect different bacterial loads (i.e., $>10^{3}$ or $10^{5} \mathrm{cfu} / \mathrm{ml}$ ). An example of an automated urinalysis instrument is the Sysmex urine fluorescence flow cytometer (Sysmex UF-1000i). This instrument uses an algorithm which combines the quantitative detection of bacteria and white blood cells to determine if infection is present. Screening-positive samples can be further analyzed with urine culture reducing the amount of microbiology tests and minimizing unnecessary antibiotic therapy in case of screening-negative samples. Although associated with distinct advantages such as the ability of the Sysmex system to adjust settings to cover either bacterial loads $>10^{3}$ or $10^{5} \mathrm{cfu} / \mathrm{ml}$, this system, as well as the dipstick testing, show limitations in clinical sensitivity and do not provide 
an identification of the uropathogen involved. Especially in a hospital setting, where often a larger variation in the different bacteria causing UTIs is found as compared to at the general practitioners, uropathogen identification might prove essential to aid in rapid and adequate treatment.

The aim of this study was to develop a new molecular approach accounting for both rapid semi-quantification of the bacterial load in urine as well as the identification of the uropathogen. This UTI screening assay was based on the earlier described multi-probe 16S rDNA-based real-time PCR assay using species- and genus-specific probes ${ }^{12}$. The most promising new feature evaluated in the current study was the semi-quantitative breakpoint to distinguish between positive and negative urinary samples. The discriminatory breakpoint was based on the scattering in cycle threshold (Ct) values of the universal $16 \mathrm{~S}$ rDNA probe. In this study, we defined significant bacteriuria as an uropathogen load $\geq 10^{5} \mathrm{cfu} / \mathrm{ml}$ and low-level bacteriuria as a load between $10^{3}$. $10^{4} \mathrm{cfu} / \mathrm{ml}$. Bacterial loads below $10^{3} \mathrm{cfu} / \mathrm{ml}$ were considered to be no UTI. The other purpose of the UTI screening tool was to offer a rapid indication about the causative agent. The pathogens selected as target in the real-time PCR assay were Escherichia coli, Pseudomonas spp., P. aeruginosa, Staphylococcus spp., Staphylococcus aureus, Enterococcus spp., and Streptococcus spp.

\section{Materials and methods}

\section{Clinical samples}

We included 225 clinical urine samples submitted to the Medical Microbiology Laboratory of the Maastricht University Medical Center (MUMC+, Maastricht, The Netherlands). The samples were collected from in- and outpatients, which had a clinical suspicion of a UTI. Conventional processing of the urine specimens consisted of dipstick testing for nitrite and/or further pathogen identification by Gram stain and biochemical testing. Samples were cultured using standard microbiological methods. Identification and antibiotic susceptibility testing was performed with the Phoenix system (BD Diagnostic Systems). Colony counts of $\geq 10^{5} \mathrm{cfu} / \mathrm{ml}$ were considered as the presence of significant bacteriuria. All samples were used according to the code for proper use of human tissue as formulated by the Dutch Federation of Medical Scientific Societies.

\section{Processing of urine samples}

$1 \mathrm{ml}$ of urine sample was centrifuged for $5 \mathrm{~min}(13,400 \times \mathrm{g})$. The supernatant was removed and the remaining pellet was washed with $900 \mu \mathrm{l}$ phosphate buffered saline (PBS) and centrifuged for $5 \mathrm{~min}(13,400 \times \mathrm{g})$. Again, the 
supernatant was removed and the pellet was incubated in a lysozymelysostaphyn $(0.1 \mathrm{mg}-0.01 \mathrm{mg})$ mixture for $15 \mathrm{~min}$ at $37^{\circ} \mathrm{C}$. After this pretreatment, DNA isolation was performed with the QIAamp DNA Mini Kit according to the manufacturer's instructions (Qiagen, Hilden, Germany). Finally, DNA was eluted in $100 \mu \mathrm{l}$ of nuclease-free $\mathrm{H}_{2} \mathrm{O}$. To check for optimal DNA isolation and inhibition during amplification each sample was spiked with mCMVgB.

\section{Multiprobe assay}

The primers and the universal bacterial TaqMan probe have been described previously ${ }^{13}$. The probes for Pseudomonas spp., P. aeruginosa, E. coli, Staphylococcus spp., S. aureus, Enterococcus spp., Streptococcus spp. were previously designed and described ${ }^{12}$. Each test contained $5 \mu$ purified sample and $20 \mu \mathrm{l}$ reaction mixture. The reaction mixture contained $12.5 \mu \mathrm{l}$ of Taqman Environmental Master Mix 2.0 (Applied Biosystems, Foster City, CA, USA), 0.9 $\mu \mathrm{M}$ of forward primer, $0.6 \mu \mathrm{M}$ of reverse primer, and $0.2 \mu \mathrm{M}$ of each probe. There were four separate reactions: I) universal probe, Pseudomonas spp. probe and E. coli probe, II) P. aeruginosa probe, III) Staphylococcus spp. probe, the $S$. aureus probe and the Enterococcus spp. probe, IV) Streptococcus spp. probe. Reactions were performed on the ABI PRISM ${ }^{\circledR} 7900$ real-time PCR System (Applied Biosystems, Foster City, CA, USA) and optimal thermal cycling conditions were as follows: $10 \mathrm{~min}$ at $50^{\circ} \mathrm{C}$, initial denaturation at $95^{\circ} \mathrm{C}$ for 15 min, 42 cycles of denaturation for $15 \mathrm{~s}$ at $95^{\circ} \mathrm{C}$ and annealing at $60^{\circ} \mathrm{C}$ for $1 \mathrm{~min}$. Cycle threshold $(\mathrm{Ct})$, the cycle number at which amplicon fluorescence exceeded the preset detection threshold, was recorded for all samples. The threshold for the $\mathrm{Ct}$ analysis was manually adjusted to 0.1 , together with the baseline start and end (cycle): 6-15.

\section{Statistical analysis}

The positive predictive value (PPV), negative predictive value (NPV), sensitivity and specificity were calculated for the real-time PCR using the presence of $\geq$ $10^{5} \mathrm{cfu} / \mathrm{ml}$ in culture as gold standard. For the statistical analysis, data were analyzed using SPSS software, version PASW Statistics 18 (SPSS Inc, Chicago IL, USA). Receiver Operating Characteristics (ROC) curve analysis was performed to determine a real-time PCR-based semi-quantitative breakpoint. The Mann-Whitney $U$ Test and Kruskal-Wallis Test were used to enable correlation of the PCR Ct values with the bacterial load determined in culture. A $p$-value of $<0.05$ was considered significant. 


\section{Results}

\section{Population and assay characteristics}

The collection of urine specimens consisted of 225 samples, of which 186 samples were analyzed retrospectively using the multiprobe assay. Six samples were excluded because of insufficient sample volume, 32 urine specimens were determined as skin flora and one sample was excluded because of a fungal infection. In our test collection, the prevalence of a positive urine culture was $39 \%$. The complete assay including DNA extraction and real-time PCR could be performed within four hours.

\section{A semi-quantitative breakpoint for the detection of significant bacteriuria}

Within the Maastricht University Medical Center, urine samples (in conjunction with the matching clinical symptoms) are categorized into two groups: UTI if bacteria are present at a concentration equal or higher than $10^{5} \mathrm{cfu} / \mathrm{ml}$ and no UTI if the concentration of the bacteria is less than $10^{5} \mathrm{cfu} / \mathrm{ml}$. In this study, we also wanted to determine a semi-quantitative real-time PCR-based cut-off value to distinguish between UTI and no UTI. Therefore, the universal 16S rDNA probe was used as target, and $\mathrm{Ct}$ values were related to the cut-off value applied in culture. To evaluate the accuracy and the discriminating power of our diagnostic test, a ROC curve was made (Figure 1). The real-time PCR assay showed a good accuracy (AUC=0.93).

Following, the threshold used to discriminate between positive and negative urine samples was set to a Ct value of 25 , resulting in a significant difference in Ct value between the UTI and no UTI group (Figure 2). Using this cut-off value, a sensitivity and specificity of $97 \%$ and $75 \%$ respectively, could be reached. The positive and negative predictive values were $71 \%$ and $98 \%$, respectively (Table 1).

Table 1. Performance characteristics of the diagnostic test (real-time PCR assay, universal probe) using $\mathrm{Ct} 25$ as semi-quantitative cut-off value.

\begin{tabular}{|c|c|c|c|c|c|c|}
\hline \multirow[b]{2}{*}{$\begin{array}{l}\text { Diagnostic test } \\
\text { result }\end{array}$} & \multicolumn{2}{|c|}{ Urine culture } & \multirow[b]{2}{*}{ Sens } & \multirow[b]{2}{*}{ Spec } & \multirow[b]{2}{*}{ PPV } & \multirow[b]{2}{*}{ NPV } \\
\hline & $\begin{array}{c}\geq 10^{5} \\
\mathrm{cfu} / \mathrm{ml}\end{array}$ & $\begin{array}{l}<10^{5} \\
\mathrm{cfu} / \mathrm{ml}\end{array}$ & & & & \\
\hline PCR positive & 70 & 29 & 97 & 75 & 71 & 98 \\
\hline PCR negative & 2 & 85 & & & & \\
\hline $\begin{array}{l}\text { PPV }=\text { positive prec } \\
\text { Spec }=\text { specificity }\end{array}$ & e value; & $\mathrm{VV}=\mathrm{ne}$ & ve pre & & & \\
\hline
\end{tabular}




\section{ROC Curve}

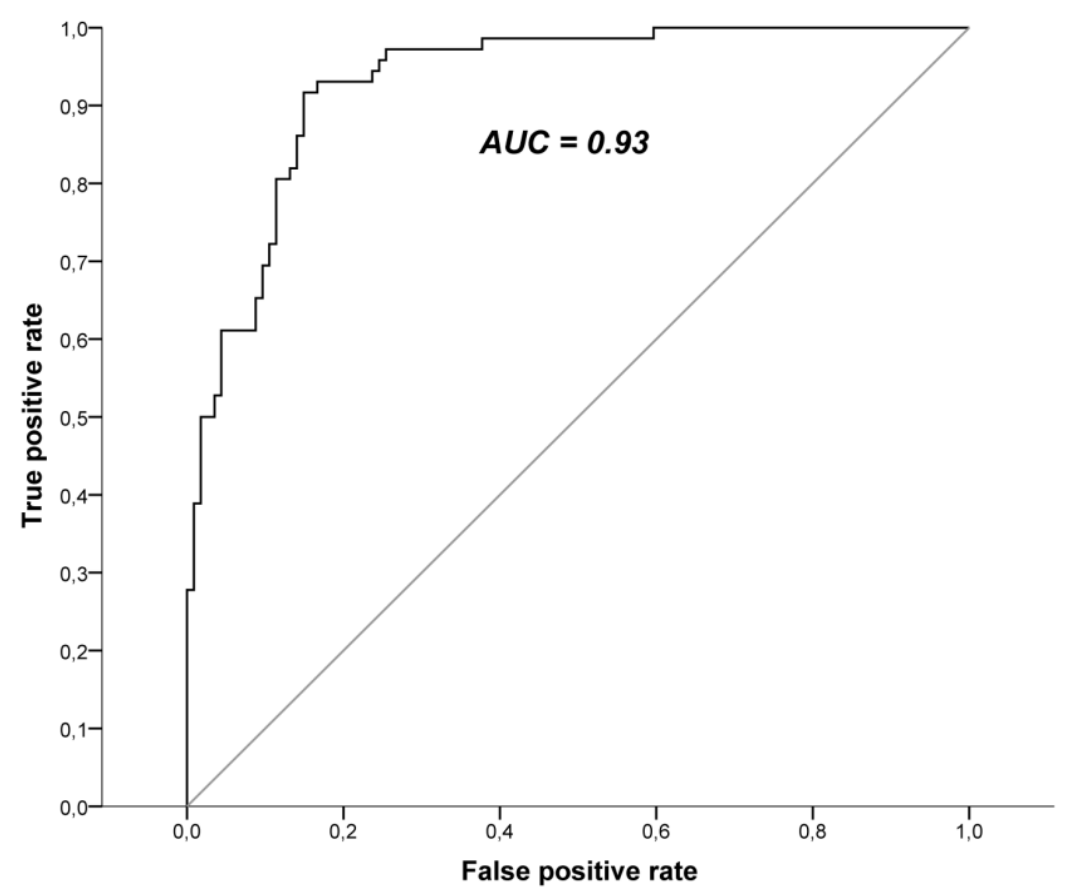

Figure 1. Receiver Operating Characteristic (ROC) decision plot obtained by using the real-time PCR Ct values (universal probe) versus urine culture results (Cut-off value of $\geq 10^{5} \mathrm{cfu} / \mathrm{ml}$ ).

As shown in Figure 2, two culture-positive samples were false-negative in our diagnostic PCR assay (Ct value of 29.56 and 26.62). An internal amplification control showed that the late signals were not due to inhibition (data not shown). The first sample contained Enterococcus faecalis $\left(10^{5} \mathrm{cfu} / \mathrm{ml}\right)$, and the second Enterobacter cloacae ( $>10^{5} \mathrm{cfu} / \mathrm{ml}$ ). Furthermore, we observed 29 false-positive results with $\mathrm{PCR}$, of which in five cases the culture report mentioned the presence of a specific pathogen between $10^{4}$ and $10^{5} \mathrm{cfu} / \mathrm{ml}$. In the remaining 24 cases no bacteria were found in culture. Adjusting the cut-off value to $\mathrm{Ct} 30$ could resolve the two false-negative results. However, then the amount of falsepositive isolates would increase to 72 cases. In Table 2, a summary is given of the performance characteristics of the PCR assay using alternative cut-off values. 


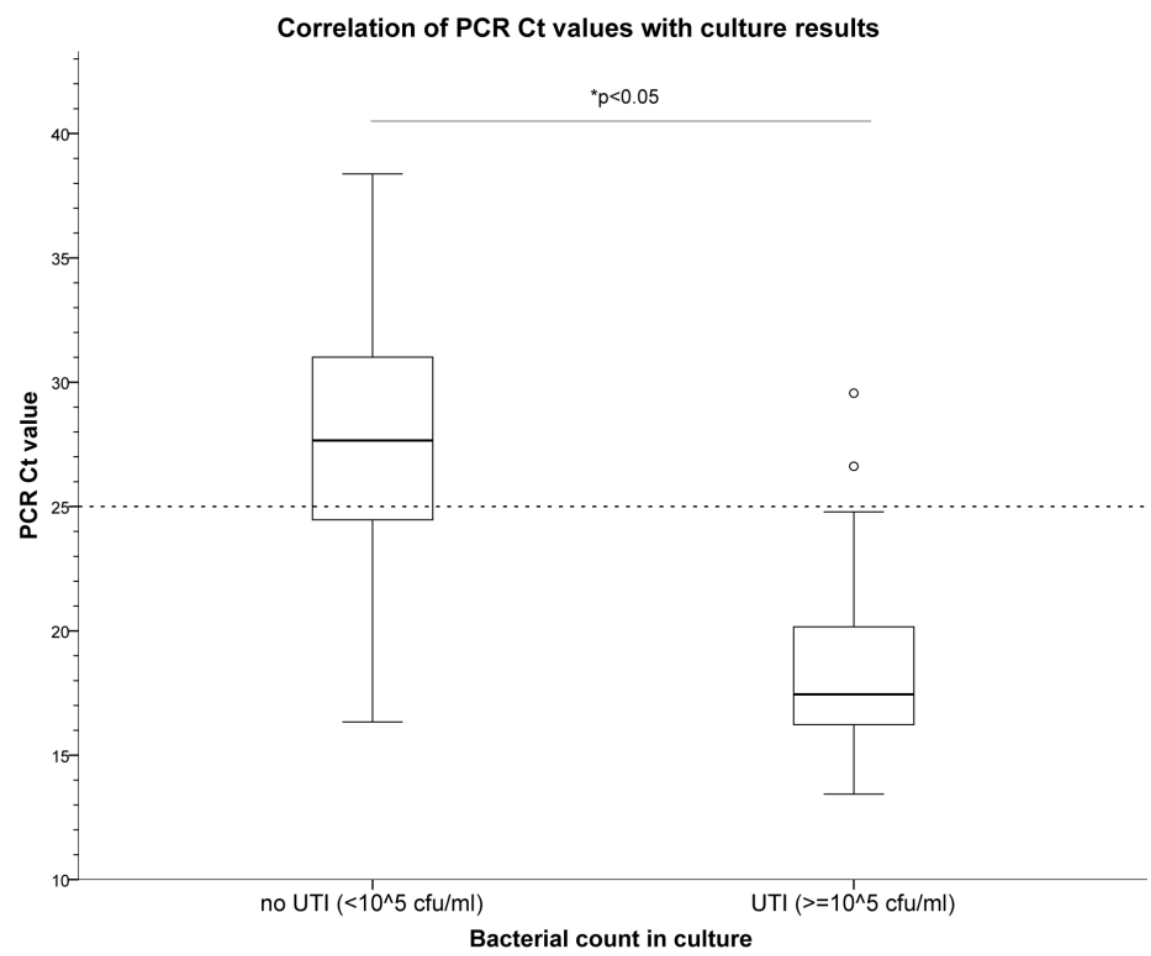

Figure 2. Correlation of $\mathrm{Ct}$ values with culture results. Based on culture, samples were categorized into two groups: UTI $\left(\geq 10^{5} \mathrm{cfu} / \mathrm{ml}\right)$ and no UTI $\left(<10^{5} \mathrm{cfu} / \mathrm{ml}\right)$. The universal 16S rDNA probe, of which a $\mathrm{Ct}$ value of 25 was set as breakpoint, was used to distinguish between positive and negative samples (line in dots). ${ }^{*} p<0.05$ (nonparametric Mann-Whitney Test)

\section{An alternative cut-off value for the diagnosis of UTI}

In different guidelines as well as in different population groups, cut-off values of $10^{3}-10^{4} \mathrm{cfu} / \mathrm{ml}$ may be considered for the definition of UTI. In Figure 3, the Ct values of the universal probe were scattered against the bacterial load determined in culture. Both the presence of $\geq 10^{5} \mathrm{cfu} / \mathrm{ml}$ of a single uropathogen as well as $10^{3}$ and $10^{4} \mathrm{cfu} / \mathrm{ml}$ were studied. Statistical analysis showed that there was a significant $(p<0.05)$ difference in $\mathrm{Ct}$ values between the three categories. Based on the $\mathrm{Ct}$ value of the universal 16S rDNA probe, a differentiation can be made between the different cut-off bacterial loads. 
Table 2. Comparison of performance characteristics of the diagnostic test (real-time PCR assay, universal probe) using different Ct cut-off values (25-30). Ct 25 was used as definitive cut-off value (marked in grey).

\begin{tabular}{ccccc}
\hline Cut-off value & Sensitivity & Specificity & PPV & NPV \\
\hline $\mathbf{2 4}$ & 94 & 76 & 72 & 96 \\
$\mathbf{2 5}$ & 97 & 75 & 71 & 98 \\
$\mathbf{2 6}$ & 97 & 68 & 65 & 97 \\
$\mathbf{2 7}$ & 99 & 56 & 59 & 98 \\
$\mathbf{2 8}$ & 99 & 48 & 55 & 98 \\
$\mathbf{2 9}$ & 99 & 42 & 52 & 98 \\
$\mathbf{3 0}$ & 100 & 37 & 50 & 100 \\
\hline
\end{tabular}

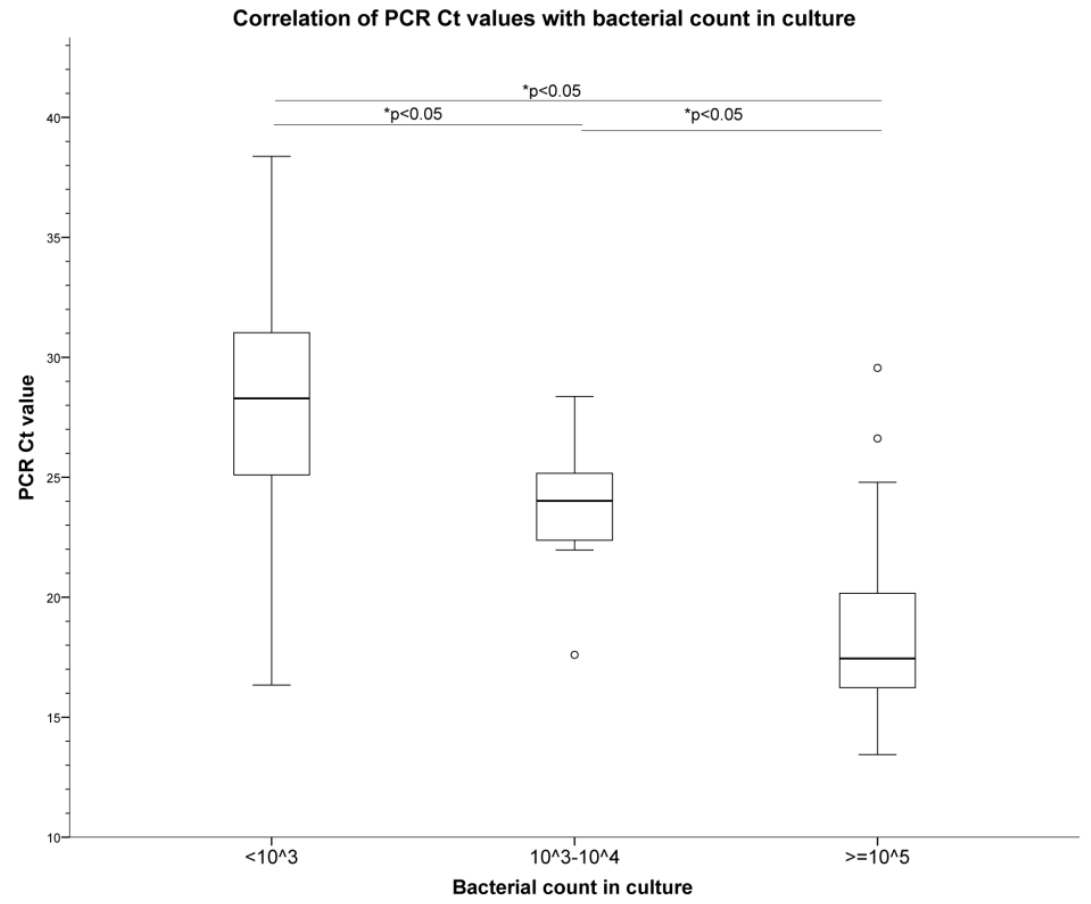

Figure 3. Boxplot showing the correlation of PCR Ct values with bacterial load determined in culture. Culture results were grouped into three categories: $<10^{3} \mathrm{cfu} / \mathrm{ml}$, $10^{3}-10^{4} \mathrm{cfu} / \mathrm{ml}$ and $\geq 10^{5} \mathrm{cfu} / \mathrm{ml}$. Statistical significance was determined performing Kruskal-Wallis Test. 
Molecular probes for the identification of the most prevalent uropathogens

The real-time PCR assay was, in addition to the universal 16S rDNA probe, complemented with seven genus- or species-specific probes. In this way, parallel to the differentiation between UTI and no UTI with the eubacterial 16S probe, the multiprobe assay also offered a first identification of clinically relevant uropathogens. We analyzed 186 urine specimens, of which 64 samples were considered as significant bacteriuria because of the presence of $\geq 10^{5} \mathrm{cfu} / \mathrm{ml}$ of a single uropathogen (Table 3. I). The $\mathrm{Ct}$ value derived from the universal $16 \mathrm{~S}$ rDNA probe was used as reference point. If no other probe generated a signal within four Ct proximity of the universal probe, the pathogen was identified as 'other', being a pathogen not included in the bacterial panel. The panel of probes could identify $76.5 \%$ of the pathogens present in the samples with monomicrobial infections. E. coli was the most frequently found uropathogen (59\%), and was $100 \%$ correctly identified with the specific probe. The other probes targeting Staphylococcus spp., Enterococcus spp., Pseudomonas spp., $P$. aeruginosa also showed a detection rate of $100 \%$. One sample containing a Streptococcus spp. was missed, resulting in a detection rate of $75 \%$. In eight isolates, a polymicrobial infection was shown (Table 3. II). The assay was able to identify more than one microorganism within the same sample. As shown in Table 3 (III), in seven cases pathogens were found both in culture and in PCR, but were, because of the presence of low counts, considered as no UTI. In summary, the assay as identification tool achieved an agreement of $98 \%$ in the samples with monomicrobial infections. 
Table 3. Pathogen identification of the 72 growth-positive urine specimens (I. Monomicrobial infections, II. Polymicrobial infections, III. Pathogens present $<10^{5} \mathrm{cfu} / \mathrm{ml}$, no UTI))

\begin{tabular}{|c|c|c|c|}
\hline CULTURE & \multicolumn{3}{|l|}{$\underline{\mathrm{PCR}}$} \\
\hline Pathogen & ID probe & $\mathrm{n}$ & Concordance (\%) \\
\hline \multicolumn{4}{|l|}{ I. Monomicrobial UTI ( $n=64)$} \\
\hline Acinetobacter baumanii & Other $^{\mathrm{a}}$ & 1 & \\
\hline beta-hemolytic Streptococcus spp. & Streptococcus spp. & $3 / 4$ & $75 \%$ \\
\hline Citrobacter braakii & Other & 1 & \\
\hline Citrobacter freundii & Other & 1 & \\
\hline Coagulase-negative Staphylococcus spp. & Staphylococcus spp. & $1 / 1$ & $100 \%$ \\
\hline Enterobacter cloacae & Other & 2 & \\
\hline Enterococcus faecalis & Enterococcus spp. & $6 / 6$ & $100 \%$ \\
\hline Escherichia coli & Escherichia coli & $38 / 38$ & $100 \%$ \\
\hline Klebsiella pneumoniae & Other & 7 & \\
\hline Proteus mirabilis & Other & 2 & \\
\hline Pseudomonas aeruginosa & Pseudomonas aeruginosa $^{\mathrm{b}}$ & $1 / 1$ & $100 \%$ \\
\hline Total (pathogens included in PCR panel) & & $49 / 50$ & $98 \%$ \\
\hline \multicolumn{4}{|l|}{ II. Polymicrobial UTI (n=8) } \\
\hline $\begin{array}{l}\text { Citrobacter freundii, Enterococcus faecalis } \\
\text { Escherichia coli, Enterococcus faecalis, Candida } \\
\text { spp. } \\
\text { Escherichia coli, Pseudomonas aeruginosa, } \\
\text { Enterococcus faecalis } \\
\text { Escherichia coli, skin flora } \\
\text { Klebsiella oxytoca, Escherichia coli } \\
\text { Klebsiella pneumoniae, Proteus mirabilis } \\
\text { Klebsiella pneumoniae, Proteus mirabilis } \\
\text { Proteus vulgaris, Enterobacter aerogenes }\end{array}$ & $\begin{array}{l}\text { Escherichia coli, Enterococc } \\
\text { Other, Staphylococcus spp. } \\
\text { Escherichia coli, Streptococe } \\
\text { Other } \\
\text { Other, Enterococcus spp. } \\
\text { Other }\end{array}$ & us spp. & as aeruginosa \\
\hline \multicolumn{4}{|l|}{ III. Uropathogens present $<10^{5} \mathrm{cfu} / \mathrm{ml}$} \\
\hline Escherichia coli & Escherichia coli & $3 / 3$ & \\
\hline Klebsiella pneumoniae & Other & 1 & \\
\hline Proteus mirabilis & Other & 2 & \\
\hline Pseudomonas aeruginosa & Pseudomonas aeruginosa & $2 / 2$ & \\
\hline
\end{tabular}

${ }^{a}$ None of the species- or genus-specific probes generated a signal, only the universal 16S rDNA probe was positive, indicating the presence of another pathogen, not included in the bacterial panel of the real-time PCR assay. ${ }^{b}$ The isolate was identified as $P$. aeruginosa, and this was shown by positive signals from both the Pseudomonas spp. and the $P$. aeruginosa probe. 


\section{Discussion}

In this study, we present a novel molecular approach which utilised all capabilities of broad-spectrum real-time PCR to aid in the diagnosis of UTls. The assay detecting the majority of uropathogens as well as a universal probe detecting eubacteria was used to establish a breakpoint that could distinguish urinary samples with significant, or low or no bacteriuria. Secondly, this screening assay was reinforced with rapid uropathogen identification. The assay presented in this study is based on the detection of $16 \mathrm{~S}$ rDNA gene signatures in real-time PCR. The universal probe targeting the 16S rDNA gene was used to establish a discriminatory set point between bacteriuria and no bacteriuria. In order to prevent positive samples to be falsely considered as negative, the assay needed to have a high sensitivity and negative predictive value. A Ct value of 30 could be applied to achieve a sensitivity and NPV of $100 \%$. However, we selected a Ct value of 25 as breakpoint because we wanted to find a proper balance between the amount of false-negative and false-positive samples. Ultimately, screening of urinary samples with our assay resulted in a sensitivity and NPV of $97 \%$ and $98 \%$, respectively.

Thus far, another rapid approach that has been presented to distinguish bacteriuria from no bacteriuria has been the Sysmex UF-100/500/1000i urine flow cytometer. Many different studies have shown that performance characteristics could be quite different because of variable cut-off values for white blood cells (WBC) and bacteria ${ }^{3,6,14-17}$. Traditionally, often significant bacteriuria is defined as the presence of $\geq 10^{5} \mathrm{cfu} / \mathrm{ml}^{18,19}$. In recent years, both the American Society of Microbiology (ASM) and European urinalysis guidelines have recommended colony counts of $\geq 10^{3} \mathrm{cfu} / \mathrm{ml}$ of uropathogens to be reported as $\mathrm{UTI}^{20}$. Therefore, we investigated if further subdivision was possible with this UTI-screening assay. Indeed, we could find a significant difference in $\mathrm{Ct}$ value when three instead of two categories were made, as shown in Figure 3. But, lowering the cut-off value in culture, would result in an increase in the amount of contaminants that would be reported.

In order to establish whether the bacterial load in urine is a result of a high load of uropathogens or of contaminating skin flora, the second part of the assay, i.e. the identification of the pathogen, can be of great value. We saw that the absolute $\mathrm{Ct}$ value of the universal probe can be linked to the absolute $\mathrm{Ct}$ value of the specific probes. So, if the urinary sample contained a microorganism not included in the panel, the Ct value of the universal probe is that low, indicating the presence of another pathogen. From our results it became apparent that when the specific probe generated a signal within four $\mathrm{Ct}$ of the universal probe, we could define this as the causative agent. The current panel included probes for the most frequently found uropathogens i.e. E. coli, Pseudomonas spp., and Staphylococcus spp. A possible future target could be Klebsiella pneumonia 
since the prevalence was similar to Enterococcus spp. As shown in Table $3 \mathrm{III}$, the assay could also identify polymicrobial infections. In these cases, it was also more likely to find contaminants such as Staphylococcus spp. and Streptococcus spp. A report by Wu et al. presented a similar approach, using $\mathrm{FISH}$ with specific probes for the identification of uropathogens ( $E$. coli, $E$. faecalis and $S$. aureus). The sensitivity of the E. coli specific probe was $95 \%$, whereas the specificity of the $S$. aureus probe was $98 \%{ }^{21}$. The clinical relevance of the $S$. aureus probe can be discussed since it was not detected as causative agent in our sample collection. Thus in future studies, this probe could potentially be deleted from the current assay. Lehmann et al. developed a real-time PCR consisting of species-specific probes for 15 pathogens and achieved a sensitivity and specificity of $90 \%$ and $87 \%$, respectively ${ }^{22}$. Taken together, our novel approach can be of significant relevance for the rapid diagnosis of UTI because of the ability to distinguish between lower counts and significant bacteriuria, and this combined with the identification of the uropathogen. Identification of a uropathogen is especially vital in hospital settings because of a more diverse UTI etiology.

Overall, the UTI screening and identification assay showed good performance characteristics. In $76.5 \%$ of the monomicrobial infections, the bacterial panel correctly diagnosed the causative agent and results were available as soon as within four hours. One isolate could not be identified as Streptococcus spp. The remaining $22 \%$ contained microorganisms not included in the bacterial panel. The limited number of bacterial targets could be a limitation of the assay, though the most important uropathogens are included. Another potential limitation of the assay is that the use of real-time PCR supplemented with molecular probes is more expensive than urine culture. Though, future applications concerning miniaturisation of PCR such as micro fluidic digital PCR could be used to offer rapidity, high-throughput and lower running costs, making this assay more cost-effective. The most important feature of the assay was the capability to categorize into no bacteriuria $\left(<10^{3} \mathrm{cfu} / \mathrm{ml}\right)$, low-level bacteriuria $\left(10^{3}-10^{4} \mathrm{cfu} / \mathrm{ml}\right)$ and significant bacteriuria $\left(\geq 10^{5} \mathrm{cfu} / \mathrm{ml}\right)$. Additionally, in this study, screening of urinary specimens would have reduced the amount of urine specimens to be cultured with $47 \%$. In summary, the assay could be of great value to improve the diagnosis and therapy of UTIs, especially in hospital settings.

\section{References}

1. Peleg AY, Hooper DC. Hospital-acquired infections due to gram-negative bacteria. N Engl J Med 2010; 362: 1804-13.

2. Stamm WE, Hooton TM. Management of urinary tract infections in adults. $N$ Engl $J$ Med 1993; 329: 1328-34. 
3. Broeren MA, Bahceci S, Vader $\mathrm{HL}$ et al. Screening for urinary tract infection with the Sysmex UF-1000i urine flow cytometer. J Clin Microbiol 2011; 49: 1025-9.

4. Nicolle LE, Bradley S, Colgan R et al. Infectious Diseases Society of America guidelines for the diagnosis and treatment of asymptomatic bacteriuria in adults. Clin Infect Dis 2005; 40: 643-54.

5. Okada HOURS, Sakai $Y$, Miyazaki $S$ et al. Detection of significant bacteriuria by automated urinalysis using flow cytometry. J Clin Microbiol 2000; 38: 2870-2.

6. Brilha S, Proenca HOURS, Cristino JM et al. Use of flow cytometry (Sysmex) UF-100) to screen for positive urine cultures: in search for the ideal cut-off. Clin Chem Lab Med 2010; 48: 289-92.

7. Jolkkonen S, Paattiniemi EL, Karpanoja $P$ et al. Screening of urine samples by flow cytometry reduces the need for culture. J Clin Microbiol 2010; 48: 3117-21.

8. Deville WL, Yzermans JC, van Duijn NP et al. The urine dipstick test useful to rule out infections. A meta-analysis of the accuracy. BMC Urol 2004; 4: 4.

9. Williams GJ, Macaskill P, Chan SF et al. Absolute and relative accuracy of rapid urine tests for urinary tract infection in children: a meta-analysis. Lancet Infect Dis 2010; 10: 240-50.

10. Wilson ML, Gaido L. Laboratory diagnosis of urinary tract infections in adult patients. Clin Infect Dis 2004; 38: 1150-8.

11. Nys $\mathrm{S}$, van Merode $\mathrm{T}$, Bartelds $\mathrm{Al}$ et al. Urinary tract infections in general practice patients: diagnostic tests versus bacteriological culture. J Antimicrob Chemother 2006; 57: 955-8.

12. Hansen WL, Beuving J, Bruggeman CA et al. Molecular probes for diagnosis of clinically relevant bacterial infections in blood cultures. J Clin Microbiol 2010; 48: 4432-8.

13. Nadkarni MA, Martin FE, Jacques NA et al. Determination of bacterial load by real-time PCR using a broad-range (universal) probe and primers set. Microbiology 2002; 148: 25766.

14. Zaman Z, Roggeman S, Verhaegen J. Unsatisfactory performance of flow cytometer UF100 and urine strips in predicting outcome of urine cultures. J Clin Microbiol 2001; 39: 4169-71.

15. Manoni F, Fornasiero L, Ercolin M et al. Cutoff values for bacteria and leukocytes for urine flow cytometer Sysmex UF-1000i in urinary tract infections. Diagn Microbiol Infect Dis 2009; 65: 103-7.

16. van der Zwet WC, Hessels J, Canbolat F et al. Evaluation of the Sysmex UF-1000i(R) urine flow cytometer in the diagnostic work-up of suspected urinary tract infection in a Dutch general hospital. Clin Chem Lab Med 2010; 48: 1765-71.

17. Kadkhoda K, Manickam K, Degagne P et al. UF-1000i flow cytometry is an effective screening method for urine specimens. Diagn Microbiol Infect Dis 2011; 69: 130-6.

18. Kass EH. Asymptomatic infections of the urinary tract. Trans Assoc Am Physicians 1956; 69: 56-64.

19. Kass EH. Bacteriuria and the diagnosis of infections of the urinary tract; with observations on the use of methionine as a urinary antiseptic. AMA Arch Intern Med 1957; 100: 709-14.

20. Medicine ECoL. European urinalysis guidelines: summary. Scand J Clin Lab Invest Supp/ 2000; 60: 1-96.

21. Wu Q, Li Y, Wang $M$ et al. Fluo rescence in situ hybridization rapidly detects three different pathogenic bacteria in urinary tract infection samples. J Microbiol Methods 2010; 83: 1758.

22. Lehmann LE, Hauser S, Malinka T et al. Real-time polymerase chain-reaction detection of pathogens is feasible to supplement the diagnostic sequence for urinary tract infections. BJU Int 2010; 106: 114-20. 




\section{Chapter 5}

\section{Rapid identification and genotypic antibiotic resistance determination of staphylococci}

Wendy L. J. Hansen, Ellen E. Stobberingh, Cathrien A. Bruggeman, Petra F. G. Wolffs 


\section{Abstract}

A genotypic approach for positive blood cultures was developed for the rapid identification and determination of the most relevant antimicrobial resistance phenotypes occurring in staphylococci. The identification of the staphylococci was based on 16S rDNA gene amplification and was achieved using probes for Staphylococcus species and Staphylococcus aureus. Primers targeting the genes mecA, blaz, aac(6')-aph(2"), vanA, ermA, ermC and msrA were selected to enable profiling of the staphylococcal antimicrobial resistance profile. Current routinely used phenotypic methods require further culturing steps resulting in a delay of at least 24 hours. In this study, the identification panel achieved a correlation of $100 \%$ with conventional bacterial identification. Next, we found a categorical agreement of $96 \%$ between the conventional antibiotic susceptibility testing and the genotypic resistance profiles detected with our real-time PCR assay. Combined, these data showed a high agreement between conventional phenotypic and genotypic testing and could drastically reduce the time needed for analysis. The use of both this identification and antibiotic resistance determination panel allowed the analysis of positive blood cultures within two hours and could therefore be of significant relevance for improvement of diagnostic methods involved in bloodstream infections. 


\section{Introduction}

In patients with a suspicion of bloodstream infection (BSI) information regarding the identification of the causative agent and the microorganisms' antimicrobial resistance profile is required. The importance of obtaining an antimicrobial resistance profile has been demonstrated by reports showing that the administration of appropriate antibiotics is correlated with a decrease in mortality $^{1,2}$. Conventional antimicrobial susceptibility testing (AST) methods such as the agar dilution test, microdilution assay, E-test and disk diffusion test, still involve pure subculturing and therefore take up to 24 hours before initial results are known. So, infections are treated empirically until final results are available. Based on the nature of the test, the use of a rapid, DNA-based test could shorten the time between empirical and streamlined antimicrobial therapy, and would thus be beneficial for the outcome of the patient. Genetic methods for the detection of antimicrobial resistance still need a careful exploration, though some resistance genes $(\operatorname{mec} A, \operatorname{van} A, \operatorname{van} B)^{3}$ are firmly associated with phenotypic resistance ${ }^{4}$. In fact, because of difficulties in phenotypic susceptibility testing for methicillin resistance, the detection of the mecA gene is now recognized as the most definitive method ${ }^{5}$. Despite the promise of this direct approach, potential limitations such as the large amount of resistance mechanisms that would need to be detected or the possibility that some resistance genes may not be expressed or may not result in phenotypic resistance, have to be overcome ${ }^{5}$.

The most important Gram-positive bacteria causing bloodstream infections are the staphylococci, especially Staphylococcus aureus and Staphylococcus epidermidis, which are associated with the highest pathogenicity ${ }^{6}$. Beta-lactam antibiotics, aminoglycosides, glycopeptides and macrolide, lincosamide, and streptogramin (MLS) antibiotics are all commonly used to treat infections caused by staphylococci. Both $S$. aureus and coagulase-negative staphylococci (CoNS) are known to accumulate more than one antibiotic resistance determinant, resulting in multi-drug resistant strains. Within the group of the beta-lactam antibiotics, resistance to oxacillin (methicillin) and penicillin is most frequently observed. Oxacillin resistance in staphylococci is conferred by the chromosomally located mecA gene, which encodes for an altered penicillinbinding protein PBP $2 \mathrm{a}^{7-9}$. Hence, the resistance mechanism responsible for the lowered affinity for beta-lactam antibiotics is based on the occurrence of only one resistance gene determinant. But, resistance mechanisms are mostly established by the presence of more than one antibiotic resistance gene. Examples are multiple-gene-based resistance mechanisms for vancomycin ${ }^{10,11}$ and MLS antibiotics. Within the group of the MLS antibiotics different mechanisms of acquired resistance have been found in Gram-positive bacteria $^{11}$. Target modification by methylases, which are encoded by 
erythromycin ribosome methylation (erm) genes, is the most common mechanism found. Another relevant possibility is the presence of efflux proteins, encoded by for instance the $m s r A$ gene. Presence of the $m s r A$ gene confers resistance to both macrolides and streptogramin $B$ antibiotics (MS phenotype) ${ }^{11}$ 12.

The aim of this study was to offer a clinically relevant diagnostic approach for bacterial infections using real-time PCR directly on positive blood cultures for on the one hand the identification of staphylococci and on the other hand the detection of the most important antibiotic resistance genes and to compare these results with conventional AST for beta-lactam antibiotics, glycopeptides, aminoglycosides and MLS antibiotics. The antibiotic resistance genes tested were selected based on their clinical relevance and included mecA, blaz, $\operatorname{aac}\left(6^{\prime}\right)-\operatorname{aph}\left(2^{\prime \prime}\right), \operatorname{van} A$, ermA, ermC and $m s r A$. The use of this novel antibiotic resistance testing assay in combination with rapid identification could drastically improve the diagnosis and therapy of bloodstream infections.

\section{Materials and Methods}

\section{Clinical samples and sample preparation}

Between September 2008 and March 2009, a total of 114 Staphylococcus spp. isolates from positive blood cultures were collected at the department of Medical Microbiology, Maastricht University Medical Center (MUMC+, Maastricht, The Netherlands), and included in this study. For the identification, all samples were analyzed with standard conventional testing including culture, Gram-staining and biochemical tests (catalase, coagulase and DNase production). A limited sample preparation step was performed prior to analysis of the staphylococcal isolates with the PCR-based identification assay, and our new antimicrobial resistance testing method. Briefly, an aliquot $(0.1 \mathrm{ml})$ of the blood cultures was $1: 100$ diluted in sterile $0.9 \% \mathrm{NaCl}$. After a centrifugation step of $5 \mathrm{~min}(13,400 \times \mathrm{g})$, the bacterial pellet was resuspended in $100 \mu \mathrm{l}$ of nuclease-free water. All samples were used according to the code for proper use of human tissue as formulated by the Dutch Federation of Medical Scientific Societies.

\section{Bacterial identification with multi-probe assay}

As previously described in Hansen et al., we developed a real-time PCR supplemented with molecular probes for the identification of different bacterial pathogens. For this study, one universal 16S rDNA probe and two specific probes targeting Staphylococcus spp. and $S$. aureus were used ${ }^{13}$. In addition, 
the primers and probe for femA were included in the assay for the identification of $S$. aureus ${ }^{14}$.

\section{Conventional antimicrobial susceptibility testing}

AST was performed using routine phenotypic methods according to the CLSI guidelines. A standard inoculum in Phoenix ID Broth (BD Diagnostic Systems) was prepared from the bacteria grown on the agar medium and inoculated into Phoenix panels, following the manufacturer's recommendations. In case of discrepancies between the phenotypic and genotypic method, microbroth dilution was used, as described in the CLSI guidelines ${ }^{15}$.

\section{New antimicrobial resistance testing real-time PCR assay}

We selected five antibiotic resistance phenotypes as target, including oxacillin, penicillin, gentamicin, vancomycin and erythromycin, and these were represented by seven antibiotic resistance genes (i.e., $\operatorname{mec} A$, blaz, $\operatorname{aac}(6)$ )aph(2"), vanA, ermA, ermC and msrA, respectively). The real-time PCR assay was based on non-specific fluorescent dye-based chemistries using the EvaGreen ${ }^{\circledR}$ dye. The primers for the antibiotic resistance genes blaz, aac(6)aph(2"), mecA, ermA, ermC, msrA and vanA were described previously (Table 1). Each reaction contained a $5 \mu \mathrm{l}$ purified sample and a $20 \mu \mathrm{l}$ reaction mixture. The reaction mixture contained $5 \mu$ HOT FIREPol ${ }^{\circledR}$ EvaGreen qPCR Mix Plus (Rox) (Solis BioDyne, Tartu, Estonia) and 0.6 $\mu \mathrm{M}$ forward and reverse primer. The real-time PCR was performed using the Bio-Rad IQ5 real-time PCR Detection System (Bio-Rad Laboratories, Hercules, CA). The following optimal thermal cycling conditions were used: cycle $1\left(95^{\circ} \mathrm{C}\right.$ for $\left.30 \mathrm{~s}\right)$, cycle $2\left(95^{\circ} \mathrm{C}\right.$ for $5 \mathrm{~min}$ ), cycle $342 \times$ (step 1: $95^{\circ} \mathrm{C}$ for $15 \mathrm{~s}-\operatorname{step} 2: 60^{\circ} \mathrm{C}$ for $1 \mathrm{~min}$ ), data collection, cycle $4\left(95^{\circ} \mathrm{C}\right.$ for $\left.1 \mathrm{~min}\right)$, cycle $5\left(50^{\circ} \mathrm{C}\right.$ for $\left.1 \mathrm{~min}\right)$, cycle $660 \times\left(65^{\circ} \mathrm{C}\right.$ $94.5^{\circ} \mathrm{C}$ for $10 \mathrm{~s}$ ) with increasing the set point temperature after cycle 2 by 0.5 ${ }^{\circ} \mathrm{C}$, melt curve data collection. The cycle threshold $(\mathrm{Ct})$ value and melting peak $\left(\mathrm{Tm} \pm 0.5^{\circ} \mathrm{C}\right)$ specific for each target was recorded for all samples $(\mathrm{Tm} b l a z$ $: 80^{\circ} \mathrm{C}, \mathrm{Tm}$ aac(6) $-\operatorname{aph}\left(2^{\prime \prime}\right): 78^{\circ} \mathrm{C}, \mathrm{Tm} \operatorname{mec} A: 77^{\circ} \mathrm{C}, \mathrm{Tm}$ ermA: $81.5^{\circ} \mathrm{C}, \mathrm{Tm}$ ermC: $\left.78.5^{\circ} \mathrm{C}, \mathrm{Tm} m s r A: 83^{\circ} \mathrm{C}\right)$.

\section{Data analysis}

The results of our new genotypic method for antimicrobial resistance testing (susceptible or resistant) were compared with the results of conventional AST (susceptible, intermediate or resistant) for categorical agreement. Performance characteristics of our new test were determined and included sensitivity, specificity, positive predictive value (PPV) and negative predictive value (NPV). 
Additionally, major errors (false-resistant result) and very majors errors (falsesusceptible result) were calculated as discussed in Jorgensen et al ${ }^{16}$. Minor errors (false result concerning an intermediate result) were not defined since real-time PCR could only be used to screen for the presence or absence of a specific resistance gene.

Table 1. Staphylococcal antibiotic resistance gene-specific primers used in this study.

\begin{tabular}{|c|c|c|c|}
\hline Oligonucleotide & $\begin{array}{l}\text { Resistance } \\
\text { phenotype }^{a}\end{array}$ & Sequence (5'-3') & Reference \\
\hline mecA_f & OXA & TGAAGTGGTAAAATGGTAATATCGACTTAA & 14 \\
\hline mecA_r & & TATTTCGACTGCTACTCTAGCAAAGAA & \\
\hline blaz $\bar{f}$ & PEN & АСTTCAACACCTGCTGCTTTC & 6 \\
\hline$b l a z r$ & & TGACCACTTTTATCAGCAACC & \\
\hline $\operatorname{aac}\left(6^{\prime}\right)-\operatorname{aph}\left(2^{\prime \prime}\right) \_f$ & GEN & TTGGGAAGATGAAGTTTTTAGA & 6 \\
\hline $\operatorname{aac}\left(6^{\prime}\right)-a p h\left(2^{\prime \prime}\right) \_r$ & & CCTTTACTCCAATAATTTGGCT & \\
\hline vanA_f & VAN & CATGAATAGAATAAAAGTTGCAATA & \\
\hline vanA_r & & CCCCTTTAACGCTAATACGATCAA & \\
\hline ermA_f & ERY & TATCTTATCGTTGAGAAGGGATT & 6 \\
\hline ermA_r & & CTACACTTGGCTTAGGATGAAA & \\
\hline ermC_f $f$ & ERY & CTTGTTGATCACGATAATTTCC & 6 \\
\hline ermC_r & & ATCTTTTAGCAAACCCGTATTC & \\
\hline$m s r A \_f$ & ERY & TCCAATCATTGCACAAAATC & 6 \\
\hline$m s r A \_r$ & & AATTCCCTCTATTTGGTGGT & \\
\hline
\end{tabular}

\section{Results}

A total of 114 staphylococcal isolates were included in this study, of which 33 isolates were identified as $S$. aureus and the remaining 81 isolates as CoNS using conventional culturing and identification techniques. Using our multi-probe identification assay, in which S. aureus and other Staphylococcus spp. could be distinguished, an agreement of $100 \%$ could be reached and this within two hours. The correlation between the AST and our real-time PCR assay is presented in Table 2. Each strain was tested for each target, and this resulted in a categorical agreement of $96 \%$. No strains were positive for the vanA resistance gene, the specificity of the primers was confirmed with a positive control (data not shown). In total, we defined 21 discrepancies as major error and one discrepancy as very major error.

The correlation between the phenotypic and genotypic approach, in which there was only one potential causative antibiotic resistance gene, did not show any false-susceptible strains. Among the 65 oxacillin-susceptible staphylococcal strains three carriers of the mecA gene were found (repeated MIC values of 106 
$\leq 0.25 \mathrm{mg} / \mathrm{L}, 0.25 \mathrm{mg} / \mathrm{L}$ and $0.12 \mathrm{mg} / \mathrm{L})$. Screening for gentamicin resistance resulted in the misidentification of five out of 82 susceptible strains (repeated MIC values of $<0.06 \mathrm{mg} / \mathrm{L},<0.06 \mathrm{mg} / \mathrm{L}, 1, \leq 0.25 \mathrm{mg} / \mathrm{L}$ and $\leq 0.25 \mathrm{mg} / \mathrm{L}$ ). Among the 27 penicillin-susceptible strains in 11 cases the blaz gene was detected (repeated MIC values between $0.015 \mathrm{mg} / \mathrm{L}$ and $0.12 \mathrm{mg} / \mathrm{L}$ ).

Table 2. Correlation between AST and the genotypic antibiotic resistance testing approach using real-time PCR.

\begin{tabular}{|c|c|c|c|c|c|c|c|c|}
\hline \multirow[b]{3}{*}{$\mathrm{AST}^{\mathrm{a}}$} & \multicolumn{8}{|c|}{ Genotypic antibiotic resistance testing } \\
\hline & \multicolumn{2}{|c|}{$\begin{array}{c}\text { mecA } \\
\text { oxacillin }\end{array}$} & \multicolumn{2}{|c|}{$\begin{array}{c}\text { blaZ } \\
\text { penicillin }\end{array}$} & \multicolumn{2}{|c|}{$\begin{array}{c}\operatorname{aac}\left(6^{\prime}\right)-\operatorname{aph}\left(2^{\prime \prime}\right) \\
\text { gentamicin }\end{array}$} & \multicolumn{2}{|c|}{$\begin{array}{c}\text { ermA/erm C/msrA } \\
\text { erythromcyin }\end{array}$} \\
\hline & $\mathrm{PCR}+$ & PCR- & $\mathrm{PCR}+$ & PCR- & $\mathrm{PCR}+$ & PCR- & $\mathrm{PCR}+$ & PCR- \\
\hline resistant & 49 & 0 & 87 & 0 & 32 & 0 & 50 & 1 \\
\hline susceptible & 3 & 62 & 11 & 16 & 5 & 77 & 2 & 54 \\
\hline Sens (\%) & \multicolumn{2}{|c|}{100} & \multicolumn{2}{|c|}{100} & \multicolumn{2}{|c|}{100} & \multicolumn{2}{|c|}{98} \\
\hline Spec (\%) & \multicolumn{2}{|c|}{95} & \multicolumn{2}{|c|}{59} & \multicolumn{2}{|c|}{94} & \multicolumn{2}{|c|}{96} \\
\hline PPV (\%) & \multicolumn{2}{|c|}{84} & \multicolumn{2}{|c|}{89} & \multicolumn{2}{|c|}{86} & \multicolumn{2}{|c|}{96} \\
\hline NPV (\%) & \multicolumn{2}{|c|}{100} & \multicolumn{2}{|c|}{100} & \multicolumn{2}{|c|}{100} & \multicolumn{2}{|c|}{98} \\
\hline
\end{tabular}

Table 3. Distribution of the different antibiotic resistance genes for the erythromycin resistance phenotype.

$$
\text { Erythromycin }
$$

Genotypic antibiotic resistance testing

ermA ermC msrA ermA+ermC ermC+msrA

\begin{tabular}{llllll} 
AST: resistant & 7 & 23 & 13 & 2 & 5 \\
\hline
\end{tabular}


To screen for resistance to erythromycin, we selected three antibiotic resistance genes including ermA, ermC and $m s r A$. A total of 51 strains were erythromycinresistant. The prevalence of the three different antibiotic resistance genes in our study collection is shown in Table 3. In seven of these strains ermA was present, in 23 strains ermC was present and thirteen strains contained the $m s r A$ gene. Additionally, two isolates carried both ermA and ermC, and another five isolates carried both ermC and $m s r A$. One resistant strain, with a MIC value of $>32 \mathrm{mg} / \mathrm{L}$, was missed using the genotypic real-time PCR. In two susceptible isolates ermA and ermC, respectively were detected. A repeated MIC determination confirmed the AST (MIC $\leq 0.25 \mathrm{mg} / \mathrm{L}$ ). Thus, the assay for erythromycin resistance testing correlated in $97 \%$ with the antibiotic susceptibility testing.

\section{Discussion}

This study described a novel diagnostic approach for the determination of both the identification as well as the antimicrobial resistance profile of staphylococcal isolates from positive blood cultures. The identification assay could distinguish S. aureus from other Staphylococcus spp., and included a universal 16S rDNA probe enabling detection of other bacteria as well. Among these, three probes (universal $16 \mathrm{~S}$ rDNA, Staphylococcus spp. and S. aureus probe) were originally included in the more extended bacterial panel of the multi-probe assay that was developed for the identification of the most clinically relevant bacteria causing bloodstream infections ${ }^{13}$. The identification assay was combined with a realtime PCR assay detecting seven antibiotic resistance genes. The panel of antibiotics was selected based on clinical importance and was not intended to provide a complete coverage of all AST results. In our study collection, a 96\% categorical agreement between phenotypic and genotypic testing was achieved. The main weakness of conventional AST is the time-consuming processing of patient specimens in order to obtain pure cultures. Previous reports that focused on antibiotic resistance determination in staphylococci were mainly performed on bacterial suspensions after subculturing ${ }^{17-19}$. Paule et al. developed a real-time PCR for positive blood cultures, but focused on the detection of the mecA gene for oxacillin resistance ${ }^{20}$. The group of Martineau et al. reported multiplex PCR assays including a more enlarged panel of antibiotic resistance genes, of which most of the primers in our study were selected ${ }^{6,21}$. To drastically improve the turnaround time, we combined staphylococcal identification with determination of the antimicrobial resistance profile, and tested this directly from positive blood cultures. In this way, after approximately two hours, a distinction between S. aureus and other Staphylococcus spp. could be made, together with the presence or absence of seven antibiotic resistance genes. We selected three genes to compare genotypic resistance, encoded by 
ermA, ermC and $m s r A$, with the erythromycin-resistant phenotype. Overall, except for one isolate, the selection of the genes ermA, ermC and msrA seemed to be sufficient for an accurate determination of erythromycin resistance in staphylococci. The presence of ermC (45\%) and $m s r A(35 \%)$ was highest in our collection of staphylococci, and these were only found in CoNS. Other reports by Westh et al. and Martineau et al. also found high incidences of ermC in erythromycin-resistant CoNS ${ }^{6,22}$. Eady et al. and Martineau et al. also included the detection of ermB, but since not one resistant strain carrying this gene could be found, we did not add this gene in our study ${ }^{21,23}$.

An important consequence of genotypic testing that one has to keep in mind is that the presence of a certain gene not necessarily results in phenotypic resistance. An example of this potential induction of resistance was seen when testing for oxacillin resistance. Whereas phenotypic testing identified three CoNS isolates as oxacillin-susceptible, all these isolates carried the mecA gene, described in literature as cryptically oxacillin-resistant strains (mecA-positive, but non-PBP2a-producing strain $)^{24}$. The unstable nature of oxacillin resistance was shown previously and could explain the lack of production of PBP2a and following the loss of resistance ${ }^{25,26}$. Therefore, the recognition of these cryptically oxacillin-resistant strains could be of use since they could regain their ability to produce PBP2a. In this context, the genetic detection of resistance can contribute to further investigation of the underlying nature of resistance in bacterial strains.

Of course, an important aspect that has to be well considered when designing a genotypic test for diagnostic purpose in a clinical setting is costs and laboratory equipment. In the past, Perreten et al. described the design of a microarray capable of detecting 90 antibiotic resistance genes involved in Gram-positive bacteria $^{27}$. Although this approach can be of major value in surveillance programs and for instance food safety, a diagnostic resistance tool for clinical specimens often does not need this high-output approach. In most cases, and depending on the pathogen involved, information about a restricted panel of antibiotics is requested for further streamlining of the initial empirical therapy. Furthermore, microarray-based technologies are associated with high costs, and are often not compatible with standard microbiology laboratory equipment. In summary, the combination of pathogen identification and antibiotic resistance determination of staphylococci, within two hours is of significant value for the diagnosis of bacterial infections. Furthermore, the $96 \%$ agreement between our genotypic test and conventional AST meets the selection criteria for an acceptable AST system, stated by Jorgensen ${ }^{16}$. In future, more bacterial pathogens could be analyzed with this rapid diagnostic assay if both more identification targets as well as more antibiotic resistance genes are added. Hence, after two hours of analysis, results can be processed by the clinician, enabling more adequate therapy decisions within less time. 


\section{References}

1. Kollef $\mathrm{MH}$. Inadequate antimicrobial treatment: an important determinant of outcome for hospitalized patients. Clin Infect Dis 2000; 31 Suppl 4: S131-8.

2. Ibrahim EH, Sherman $G$, Ward $S$ et al. The influence of inadequate antimicrobial treatment of bloodstream infections on patient outcomes in the ICU setting. Chest 2000; 118: $146-55$.

3. Tenover FC. DNA probes for antimicrobial susceptibility testing. Clin Lab Med 1989; 9: 341-7.

4. Jorgensen JH, Ferraro MJ. Antimicrobial susceptibility testing: a review of general principles and contemporary practices. Clin Infect Dis 2009; 49: 1749-55.

5. Jorgensen JH, Ferraro MJ. Antimicrobial susceptibility testing: special needs for fastidious organisms and difficult-to-detect resistance mechanisms. Clin Infect Dis 2000; 30: 799808.

6. Martineau F, Picard FJ, Lansac $\mathrm{N}$ et al. Correlation between the resistance genotype determined by multiplex PCR assays and the antibiotic susceptibility patterns of Staphylococcus aureus and Staphylococcus epidermidis. Antimicrob Agents Chemother 2000; 44: 231-8.

7. Chambers HF. Methicillin resistance in staphylococci: molecular and biochemical basis and clinical implications. Clin Microbiol Rev 1997; 10: 781-91.

8. de Lencastre HOURS, de Jonge BL, Matthews PR et al. Molecular aspects of methicillin resistance in Staphylococcus aureus. J Antimicrob Chemother 1994; 33: 7-24.

9. Hartman BJ, Tomasz A. Low-affinity penicillin-binding protein associated with beta-lactam resistance in Staphylococcus aureus. J Bacteriol 1984; 158: 513-6.

10. Sundsfjord A, Simonsen GS, Haldorsen BC et al. Genetic methods for detection of antimicrobial resistance. Apmis 2004; 112: 815-37.

11. Fluit AC, Visser MR, Schmitz FJ. Molecular detection of antimicrobial resistance. Clin Microbiol Rev 2001; 14: 836-71, table of contents.

12. Leclercq R. Mechanisms of resistance to macrolides and lincosamides: nature of the resistance elements and their clinical implications. Clin Infect Dis 2002; 34: 482-92.

13. Hansen WL, Beuving J, Bruggeman CA et al. Molecular probes for diagnosis of clinically relevant bacterial infections in blood cultures. J Clin Microbiol 2010; 48: 4432-8.

14. Donker GA, Deurenberg $\mathrm{RH}$, Driessen $\mathrm{C}$ et al. The population structure of Staphylococcus aureus among general practice patients from The Netherlands. Clin Microbiol Infect 2009; 15: 137-43.

15. Clinical and Laboratory Standards Institute. (2007) Performance standards for Antimicrobial Susceptibility Testing. Seventeenth Informational Supplement. CLSI Document M100-17: Clinical and Laboratory Standards Institute, 940 West Valley Road, Suite 1400, Wayne, Pennsylvania, 19087-1898, USA.

16. Jorgensen $\mathrm{JH}$. Selection criteria for an antimicrobial susceptibility testing system. $J$ Clin Microbiol 1993; 31: 2841-4.

17. Zmantar T, Chaieb K, Ben Abdallah F et al. Multiplex PCR detection of the antibiotic resistance genes in Staphylococcus aureus strains isolated from auricular infections. Folia Microbiol (Praha) 2008; 53: 357-62.

18. Bouchami O, Achour W, Mekni MA et al. Antibiotic resistance and molecular characterization of clinical isolates of methicillin-resistant coagulase-negative staphylococci isolated from bacteremic patients in oncohematology. Folia Microbiol (Praha) 2011; 56: 122-30.

19. Sabet NS, Subramaniam G, Navaratnam $P$ et al. Detection of methicillin- and aminoglycoside-resistant genes and simultaneous identification of $S$. aureus using triplex real-time PCR Taqman assay. J Microbiol Methods 2007; 68: 157-62. 
20. Paule SM, Pasquariello AC, Thomson RB, Jr. et al. Real-time PCR can rapidly detect methicillin-susceptible and methicillin-resistant Staphylococcus aureus directly from positive blood culture bottles. Am J Clin Pathol 2005; 124: 404-7.

21. Martineau F, Picard FJ, Grenier L et al. Multiplex PCR assays for the detection of clinically relevant antibiotic resistance genes in staphylococci isolated from patients infected after cardiac surgery. The ESPRIT Trial. J Antimicrob Chemother 2000; 46: 527-34.

22. Westh HOURS, Lisby G, Breysse F et al. Multiplex real-time PCR and blood culture for identification of bloodstream pathogens in patients with suspected sepsis. Clin Microbiol Infect 2009; 15: 544-51.

23. Eady EA, Ross JI, Tipper JL et al. Distribution of genes encoding erythromycin ribosomal methylases and an erythromycin efflux pump in epidemiologically distinct groups of staphylococci. J Antimicrob Chemother 1993; 31: 211-7.

24. Murakami K, Minamide $\mathrm{W}$, Wada $\mathrm{K}$ et al. Identification of methicillin-resistant strains of staphylococci by polymerase chain reaction. J Clin Microbiol 1991; 29: 2240-4.

25. Grubb WB, Annear DI. Spontaneous loss of methicillin resistance in Staphylococcus aureus at room-temperature. Lancet 1972; 2: 1257.

26. al-Salihy SM, James AM. Loss of methicillin-resistance from resistant strains of Staphylococcus aureus. Lancet 1972; 2: 331-2.

27. Perreten V, Vorlet-Fawer L, Slickers $\mathrm{P}$ et al. Microarray-based detection of 90 antibiotic resistance genes of gram-positive bacteria. J Clin Microbiol 2005; 43: 2291-302. 

Chapter 6

General discussion \& summary 
A wide-ranging collection of bacteria, viruses, fungi and parasites are responsible for the estimated 15 million deaths each year due to infectious diseases ${ }^{1}$. Apart from the high morbidity and mortality numbers, infectious diseases can cause severe disability and have also been associated with a high socio-economic burden on the society ${ }^{1}$. Controlling infectious diseases is complicated and is depending on different aspects, including prevention, diagnosis and treatment. The success rate of therapy is partly influenced by a rapid and accurate diagnosis of the etiologic agent and therefore, rapid methods for the diagnosis of infectious diseases are important. New diagnostic techniques should contribute to the prevention of deaths and improve quality of life drastically. Furthermore, a rapid intervention is needed to ensure the prevention of disease spread and to anticipate on the development of drugresistant strains of certain pathogens. Although culture-based methods are commonly considered as the gold standard for the detection and identification of pathogens, the substantial delay in time to results and the insensitivity towards fastidious or slow-growing microorganisms has challenged researchers to improve current pathogen diagnostics. Molecular methods for detection and identification of bacterial and fungal microorganisms have been widely developed, and already changed the clinical practice of infectious diseases. Both protein-based (e.g., mass spectroscopy) and nucleic acid-based (amplification and/or hybridization) identification assays were introduced and are associated with increased sensitivity and specificity, detection of fastidious and slow-growing microorganisms and decreased turnaround time. But, these novel techniques are also hampered by some limitations such as the potential of false-positive results due to contamination, the impossibility to distinguish between dead and viable cells, the lack of a reference standard, and the inability to provide a full antimicrobial resistance profile. Therefore, further studies are needed to expand the current knowledge and experience related to molecular diagnostics of bacteria and fungi in infectious diseases.

From that perspective, the studies performed in this thesis focused on the improvement of detection methods for bacterial and fungal microorganisms. For this purpose, new techniques for implementation in microbiological diagnostics were searched in terms of extraction of bacterial and fungal DNA from different clinical samples, identification of pathogens using nucleic acid amplification, and determination of drug resistance using genotypic detection of antibiotic resistance genes. 


\section{The extraction of bacterial and fungal DNA from different patient specimens}

Initially, a closer look was taken at sample preparation methods for the selective extraction of microbial DNA. We studied the effect of different sample preparation and DNA isolation methods for the selective extraction of bacterial DNA from whole blood samples (Chapter 2a, 2b). Implementation of rapid molecular testing methods directly from whole blood specimens instead of using cultured materials, could contribute to a strikingly faster diagnosis of bacterial and fungal infections permitting an earlier administration of the appropriate antimicrobial therapy. Both, delayed antibiotic administration ${ }^{2}$ and use of inappropriate antimicrobial therapy $\mathrm{y}^{3-5}$ is associated with an increased mortality in patients, Furthermore, inappropriate use of antibiotics has led to emerging antibiotic resistance amongst microbial pathogens, which poses as a global health concern causing prolonged illness, greater risk of death and increased risk of infection spread ${ }^{6,7}$. The detection limit of the most optimal DNA extraction procedure in our studies was 50 colony-forming units (cfu) per $\mathrm{ml}$ of whole blood. We found that the removal of inhibitory human DNA, bacteria enrichment and use of a larger volume of blood improved the rate of successful pathogen recovery from whole blood. Though, the question remains whether this detection limit is sufficient for bacterial identification from direct specimens. Therefore, we conducted a pilot study to investigate the bacterial load in pediatric whole blood samples. Contradictory findings exist concerning the amount of circulating microorganisms in the bloodstream of pediatric patients. Although it was previously thought that the bacterial or fungal load was higher in children compared to adults ${ }^{8}$ a report by Kellogg et al. presented the occurrence of low-level bacteremia in the majority of their population ${ }^{9}$. This can be problematic since the diagnostic yield is directly related to the volume of blood sampled in both adults ${ }^{10-12}$ and children ${ }^{13,14}$. For this purpose, 20 to $30 \mathrm{ml}$ of blood per culture is recommended in adults ${ }^{15,16}$, but obviously cannot be obtained in children $(<10 \mathrm{ml})$. Overall, a low amount of bacteria was found. In $85 \%$, less than $50 \mathrm{cfu}$ per $\mathrm{ml}$ of whole blood were present, which would be below the detection limit of our real-time PCR assay following an optimized DNA extraction protocol, and result in failure of detection.

In summary, we could show that the combination of different factors i.e. blood volume, human DNA elimination and bacteria enrichment can improve the detection limit of bacterial DNA extraction methods. On the other hand, our findings together with other reports demonstrated that the bacterial load in adult $^{8}$ and pediatric samples ${ }^{9}$ are rather low, hampering the current capabilities of methods for bacterial detection directly from whole blood. 


\section{The detection and identification of bacterial and fungal pathogens}

Following bacterial and/or fungal DNA extraction, different molecular techniques can be used for the detection and identification of microorganisms. Nucleic acid amplification methods such as real-time PCR can generate results within hours, thereby anticipating on the need for rapid diagnosis of infection. In order to enable detection of the most frequently observed bacterial microorganisms found in our hospital, a real-time PCR assay was designed for the identification of both Gram-positive (Staphylococcus spp., Staphylococcus aureus, Enterococcus spp., Streptococcus spp. and Streptococcus pneumonia) and Gram-negative bacteria (Escherichia coli, Pseudomonas spp. and Pseudomonas aeruginosa). In addition, the presence or absence of any bacterial DNA (others than the targets in the panel) could be confirmed using a broad-range probe for the eubacterial 16S rDNA gene. Testing of 248 blood cultures resulted in an overall agreement of $97 \%$ with conventional culturebased bacterial identification (Chapter 3a). Since the genotypic identification of microorganisms from whole blood can be hampered by the occurrence of low bacterial loads, giving rise to false-negative results, blood cultures were used as starting material for real-time PCR analysis. The identification of the included Gram-positive and Gram-negative bacterial targets could be established within two hours, which could be used as indicator for the guidance of antimicrobial therapy. A similar approach was used for the design of a real-time PCR assay identifying four clinically relevant Candida spp. from blood culture material (Chapter 3b). Invasive infections with Candida spp. have been associated with high mortality rates, ranging from $38 \%$ to $74 \%{ }^{17}$. In a pilot experiment, blood cultures which presented with fungal cells in Gram-staining, were tested with the molecular assay. All Candida-positive blood cultures were correctly identified at species level. In addition, the assay was able to identify Candida albicans in blood culture bottles which remained culture-negative, emphasizing the additive effect of molecular identification to phenotypic identification.

In both real-time PCR assays, priority was given to the genera or species most frequently found in blood cultures and/or those that could direct the choice of a suitable antibiotic therapy. For instance, in fungal infections, the detection of non-albicans Candida spp. is important because of the observed reduced susceptibility to frequently used antifungal agents. The use of a limited target panel did not offer a full laboratory report defining the exact etiologic agent, but did offer preliminary results covering bacterial pathogens which are frequently observed and this within two to three hours from positively flagged blood cultures. In contrast, conventional culture-based identification involving Gramstaining and biochemical testing, requires the generation of single colonies, usually reached after overnight growth. In the past, many broad-range PCR 
assays were combined with time-consuming sequencing of the 16S rDNA region ${ }^{18-21}$. More recently, commercial assays such as SeptiFast (Roche Diagnostics, Mannheim, Germany) and SepsiTest (MolZym, Bremen, Germany) were developed and evaluated ${ }^{21-26}$, and are intended for analysis of whole blood samples. These methods enable the detection of 25 to 40 sepsis-related pathogens, and can be completed within six to eight hours. An alternative is the Prove-it Sepsis (Mobidiag, Helsinki, Finland), a microarray-based system detecting 80 pathogens from blood cultures, and this within 3.5 hours ${ }^{27}$. Although these diagnostic tools offer a more extended panel of targets, and some can be directly applied to whole blood samples, more studies will have to be performed to assess their implementation in routine diagnostics. Until now, these can only be used in parallel to conventional culture-based identification, and thus lead to more costs. Our bacterial and fungal multiprobe assays were adapted to the prevalence of the most frequently encountered bacteria and fungi in our hospital, but can be streamlined and adjusted, offering both flexibility and reduced costs. Taking into account a 15 hours median time to positivity of blood cultures ${ }^{28-30}$, the turnaround time until initial results using a real-time PCR assay was approximately 18 hours. In the past, traditional phenotypic manual identification methods required a turnaround time until final result of approximately 63 and 72 hours for bacteria and fungi, respectively ${ }^{31}$. Nowadays, automated microdilution broth assays (e.g., Vitek (BioMérieux), Phoenix (Becton Dickinson) are used, offering full pathogen identification and antibiotic susceptibility testing (AST) with a turnaround time of $41.5-48$ hours $^{31}$. Next, we suggested that the determination of the bacterial load could also be of clinical value for other sample materials or applications (Chapter 4). For instance, quantification of uropathogens is essential as different bacterial loads $\left(>10^{3}\right.$ or $\left.10^{5} \mathrm{cfu} / \mathrm{ml}\right)$ are used in combination with clinical symptoms to identify urinary tract infections (UTIs) in different population groups ${ }^{32}$. The multiprobe real-time PCR assay presented in Chapter 3 was now used for both identification and semi-quantification of uropathogens. Our findings have shown the capability to categorize into no bacteriuria $\left(<10^{3} \mathrm{cfu} / \mathrm{ml}\right)$, low-level bacteriuria $\left(10^{3}-10^{4} \mathrm{cfu} / \mathrm{ml}\right)$ and significant bacteriuria $\left(\geq 10^{5} \mathrm{cfu} / \mathrm{ml}\right)$. Additionally, the molecular screening of urinary specimens would have reduced the amount of urine specimens to be cultured with $47 \%$. The potential of new less-time consuming methods was shown in previous studies ${ }^{33-36}$, especially since up to $80 \%$ of urine cultures are negative ${ }^{37}$.

To conclude, the development of rapid and highly specific real-time PCR assays has enabled identification and semi-quantification of microorganisms starting from positive blood cultures and urine specimens within two hours. Both assays were designed for clinically important bacteria and fungi and showed to be promising tools for the rapid and accurate diagnosis of infections, Implementation of these novel assays in the clinical microbiology laboratory 
could be beneficial for the patients' outcome in terms of rapid and appropriate therapy, but clinical studies are obligatory to assess the value (e.g., reduction in time to diagnosis, modification of therapy, hospital lengths of stay) of rapid diagnostics in patients settings.

\section{The genotypic detection of staphylococcal antibiotic resistance}

During recent years, a wide range of diagnostic options for the rapid identification of bacterial and fungal microorganisms from different clinical samples were developed. However, the role of conventional culture-based methods remained prominent, not only because of the inability of each novel test to be implemented as unique tool for identification and solely replace culturing, but also because of the need for further subculturing to perform antimicrobial susceptibility testing (AST). Because of the large amount of genes involved in antibiotic resistance, microarray-based technologies, in which genespecific probes are deposited on a solid surface, were presented as promising tools for the detection of large panels of antibiotic resistance genes ${ }^{38,} 39$. However, these are often not appropriate in terms of costs,laboratory equipment and user-friendly format ${ }^{40}$. As a proof of principle, we developed a real-time PCR offering a panel of the most requested and clinically relevant antibiotics to treat staphylococci and found it to be highly correlated with phenotypic AST methods (Chapter 5 ). The assay fulfilled the selection criteria for an acceptable AST system ( $>90 \%$ categorical agreement) stated by Jorgensen ${ }^{41}$, and could be performed within two hours starting from a positive blood culture. In our study, the use of blood cultures was of added value since previous reports that focused on antibiotic resistance detection in staphylococci were mainly performed on bacterial suspensions after subculturing ${ }^{42-46}$.

To conclude, if genotypic antibiotic resistance in staphylococci was combined with genotypic identification, as presented in chapter 3a, the turnaround time to results could be drastically reduced. Gaining knowledge about the etiologic agent together with a partial antibiotic resistance profile could enable more adequate therapy guidance at an earlier time point compared to conventional identification and AST. However, this field of diagnostics is still in its infancy, requiring further investigation in terms of antibiotic resistance mechanisms and prevalence of antibiotic resistance determinants. Currently, the genotypic approach can provide more rapid detection of well-established antibiotic resistance determinants such as $m e c A^{47}$, particularly of importance in the control and surveillance of methicillin-resistant $S$. aureus (MRSA), but cannot solely replace the phenotypic methods used in routine AST. 


\section{Conclusions and future perspectives}

In summary, the data presented in this thesis show the potential of molecular testing methods for the detection and identification of bacterial and fungal microorganisms in terms of rapidity, sensitivity and specificity. Also, in order to achieve maximum pathogen recovery from whole blood samples, the importance of an optimal DNA extraction method was demonstrated. Although we established an improvement in bacterial detection limit by the elimination of human DNA, and the use of larger sample volumes, further studies comparing the positivity rate between blood cultures and whole blood samples should be done in order to assess the use of direct patient specimens (i.e., without enrichment by culture). As addressed in previous papers, the administration of adequate antimicrobial therapy is correlated with a decrease in mortality, 48-50. From that perspective, the developed real-time PCR assays for the detection and identification of bacteria and fungi, together with the detection of important antibiotic resistance determinants could be important for the rapid diagnosis of certain infectious diseases. Overall, they achieved a drastic reduction in turnaround time, and offered a high sensitivity and specificity that could contribute to an improvement of current pathogen diagnostics in the clinical microbiology laboratory. Though, future studies are required that support and elaborate our findings, and prove their usefulness in clinical settings.

\section{References}

1. World Health Organization. WHO global burden of disease: 2004 update. 2008.

2. Valles J, Rello J, Ochagavia A et al. Community-acquired bloodstream infection in critically ill adult patients: impact of shock and inappropriate antibiotic therapy on survival. Chest 2003; 123: 1615-24.

3. Harbarth S, Garbino J, Pugin J et al. Inappropriate initial antimicrobial therapy and its effect on survival in a clinical trial of immunomodulating therapy for severe sepsis. Am $J$ Med 2003; 115: 529-35.

4. Ibrahim EH, Sherman G, Ward S et al. The influence of inadequate antimicrobial treatment of bloodstream infections on patient outcomes in the ICU setting. Chest 2000; 118: $146-55$.

5. Kumar A, Ellis $\mathrm{P}$, Arabi $\mathrm{Y}$ et al. Initiation of inappropriate antimicrobial therapy results in a fivefold reduction of survival in human septic shock. Chest 2009; 136: 1237-48.

6. Cosgrove SE, Sakoulas G, Perencevich EN et al. Comparison of mortality associated with methicillin-resistant and methicillin-susceptible Staphylococcus aureus bacteremia: a meta-analysis. Clin Infect Dis 2003; 36: 53-9.

7. Engemann JJ, Carmeli Y, Cosgrove SE et al. Adverse clinical and economic outcomes attributable to methicillin resistance among patients with Staphylococcus aureus surgical site infection. Clin Infect Dis 2003; 36: 592-8.

8. Yagupsky P, Nolte FS. Quantitative aspects of septicemia. Clin Microbiol Rev 1990; 3: 269-79.

9. Kellogg JA, Manzella JP, Bankert DA. Frequency of low-level bacteremia in children from birth to fifteen years of age. J Clin Microbiol 2000; 38: 2181-5. 
10. Bouza $E$, Alvarado N, Alcala $L$ et al. A randomized and prospective study of 3 procedures for the diagnosis of catheter-related bloodstream infection without catheter withdrawal. Clin Infect Dis 2007; 44: 820-6.

11. Cockerill FR, 3rd, Wilson JW, Vetter EA et al. Optimal testing parameters for blood cultures. Clin Infect Dis 2004; 38: 1724-30.

12. Jonsson B, Nyberg A, Henning C. Theoretical aspects of detection of bacteraemia as a function of the volume of blood cultured. Apmis 1993; 101: 595-601.

13. Isaacman DJ, Karasic RB, Reynolds EA et al. Effect of number of blood cultures and volume of blood on detection of bacteremia in children. $J$ Pediatr 1996; 128: 190-5.

14. Kaditis AG, O'Marcaigh AS, Rhodes KH et al. Yield of positive blood cultures in pediatric oncology patients by a new method of blood culture collection. Pediatr Infect Dis J 1996; 15: 615-20.

15. Clinical and Laboratory Standards Institute. Principles and Procedures for Blood Cultures; Approved Guideline. CLSI Document M47-A (ISBN 1-56238-641-7): Clinical and Laboratory Standards Institute, 940 West Valley Road, Suite 1400, Wayne, Pennsylvania, 19087-1898, USA, 2007.

16. Mermel LA, Maki DG. Detection of bacteremia in adults: consequences of culturing an inadequate volume of blood. Ann Intern Med 1993; 119: 270-2.

17. Chen SC, Halliday CL, Meyer W. A review of nucleic acid-based diagnostic tests for systemic mycoses with an emphasis on polymerase chain reaction-based assays. Med Mycol 2002; 40: 333-57.

18. Duan QJ, Shang SQ, Wu YD. Rapid diagnosis of bacterial meningitis in children with fluorescence quantitative polymerase chain reaction amplification in the bacterial $16 \mathrm{~S}$ rRNA gene. Eur J Pediatr 2009; 168: 211-6.

19. Mignard S, Flandrois JP. 16S rRNA sequencing in routine bacterial identification: a 30 month experiment. J Microbiol Methods 2006; 67: 574-81.

20. Qian Q, Tang YW, Kolbert CP et al. Direct identification of bacteria from positive blood cultures by amplification and sequencing of the 16S rRNA gene: evaluation of BACTEC 9240 instrument true-positive and false-positive results. J Clin Microbiol 2001; 39: 357882.

21. Wellinghausen N, Kochem AJ, Disque $C$ et al. Diagnosis of bacteremia in whole-blood samples by use of a commercial universal 16S rRNA gene-based PCR and sequence analysis. J Clin Microbiol 2009; 47: 2759-65.

22. Lehmann LE, Hunfeld KP, Steinbrucker $M$ et al. Improved detection of blood stream pathogens by real-time PCR in severe sepsis. Intensive Care Med 2010; 36: 49-56.

23. Lucignano B, Ranno S, Liesenfeld $O$ et al. Multiplex PCR allows rapid and accurate diagnosis of bloodstream infections in newborns and children with suspected sepsis. $J$ Clin Microbiol 2011; 49: 2252-8.

24. Obara HOURS, Aikawa N, Hasegawa $\mathrm{N}$ et al. The role of a real-time PCR technology for rapid detection and identification of bacterial and fungal pathogens in whole-blood samples. J Infect Chemother 2011; 17: 327-33.

25. Tsalik EL, Jones D, Nicholson B et al. Multiplex PCR to diagnose bloodstream infections in patients admitted from the emergency department with sepsis. J Clin Microbiol 2010; 48: 26-33.

26. Yanagihara $\mathrm{K}$, Kitagawa $\mathrm{Y}$, Tomonaga $\mathrm{M}$ et al. Evaluation of pathogen detection from clinical samples by real-time polymerase chain reaction using a sepsis pathogen DNA detection kit. Crit Care 2010; 14: R159.

27. Gaibani P, Rossini G, Ambretti $S$ et al. Blood culture systems: rapid detection--how and why? Int J Antimicrob Agents 2009; 34 Suppl 4: S13-5.

28. Marra AR, Edmond MB, Forbes BA et al. Time to blood culture positivity as a predictor of clinical outcome of Staphylococcus aureus bloodstream infection. J Clin Microbiol 2006; 44: $1342-6$. 
29. Peralta G, Rodriguez-Lera MJ, Garrido JC et al. Time to positivity in blood cultures of adults with Streptococcus pneumoniae bacteremia. BMC Infect Dis 2006; 6: 79.

30. Shah SS, Downes KJ, Elliott MR et al. How long does it take to "rule out" bacteremia in children with central venous catheters? Pediatrics 2008; 121: 135-41.

31. Klouche M, Schroder U. Rapid methods for diagnosis of bloodstream infections. Clin Chem Lab Med 2008; 46: 888-908.

32. Nicolle LE, Bradley S, Colgan R et al. Infectious Diseases Society of America guidelines for the diagnosis and treatment of asymptomatic bacteriuria in adults. Clin Infect Dis 2005; 40: 643-54.

33. Brilha S, Proenca HOURS, Cristino JM et al. Use of flow cytometry (Sysmex) UF-100) to screen for positive urine cultures: in search for the ideal cut-off. Clin Chem Lab Med 2010; 48: 289-92.

34. Broeren MA, Bahceci S, Vader HL et al. Screening for urinary tract infection with the Sysmex UF-1000i urine flow cytometer. J Clin Microbiol 2011; 49: 1025-9.

35. Jolkkonen S, Paattiniemi EL, Karpanoja $P$ et al. Screening of urine samples by flow cytometry reduces the need for culture. J Clin Microbiol 2010; 48: 3117-21.

36. Okada HOURS, Sakai $\mathrm{Y}$, Miyazaki $\mathrm{S}$ et al. Detection of significant bacteriuria by automated urinalysis using flow cytometry. J Clin Microbiol 2000; 38: 2870-2.

37. Kellogg JA, Manzella JP, Shaffer SN et al. Clinical relevance of culture versus screens for the detection of microbial pathogens in urine specimens. Am J Med 1987; 83: 739-45.

38. Call DR, Bakko MK, Krug MJ et al. Identifying antimicrobial resistance genes with DNA microarrays. Antimicrob Agents Chemother 2003; 47: 3290-5.

39. Sundsfjord A, Simonsen GS, Haldorsen BC et al. Genetic methods for detection of antimicrobial resistance. Apmis 2004; 112: 815-37.

40. Perreten V, Vorlet-Fawer L, Slickers $\mathrm{P}$ et al. Microarray-based detection of 90 antibiotic resistance genes of gram-positive bacteria. J Clin Microbiol 2005; 43: 2291-302.

41. Jorgensen $\mathrm{JH}$. Selection criteria for an antimicrobial susceptibility testing system. $J$ Clin Microbiol 1993; 31: 2841-4.

42. Bouchami O, Achour W, Mekni MA et al. Antibiotic resistance and molecular characterization of clinical isolates of methicillin-resistant coagulase-negative staphylococci isolated from bacteremic patients in oncohematology. Folia Microbiol (Praha) 2011; 56: 122-30.

43. Sabet NS, Subramaniam G, Navaratnam $P$ et al. Detection of methicillin- and aminoglycoside-resistant genes and simultaneous identification of $S$. aureus using triplex real-time PCR Taqman assay. J Microbiol Methods 2007; 68: 157-62.

44. Zmantar T, Chaieb K, Ben Abdallah F et al. Multiplex PCR detection of the antibiotic resistance genes in Staphylococcus aureus strains isolated from auricular infections. Folia Microbiol (Praha) 2008; 53: 357-62.

45. Martineau F, Picard FJ, Grenier L et al. Multiplex PCR assays for the detection of clinically relevant antibiotic resistance genes in staphylococci isolated from patients infected after cardiac surgery. The ESPRIT Trial. J Antimicrob Chemother 2000; 46: 527-34.

46. Martineau F, Picard FJ, Lansac $\mathrm{N}$ et al. Correlation between the resistance genotype determined by multiplex PCR assays and the antibiotic susceptibility patterns of Staphylococcus aureus and Staphylococcus epidermidis. Antimicrob Agents Chemother 2000; 44: 231-8.

47. Hallin M, Maes N, Byl B et al. Clinical impact of a PCR assay for identification of Staphylococcus aureus and determination of methicillin resistance directly from blood cultures. J Clin Microbiol 2003; 41: 3942-4.

48. Garnacho-Montero J, Garcia-Garmendia JL, Barrero-Almodovar A et al. Impact of adequate empirical antibiotic therapy on the outcome of patients admitted to the intensive care unit with sepsis. Crit Care Med 2003; 31: 2742-51. 


\section{CHAPTER 6}

49. Garnacho-Montero J, Ortiz-Leyba C, Herrera-Melero I et al. Mortality and morbidity attributable to inadequate empirical antimicrobial therapy in patients admitted to the ICU with sepsis: a matched cohort study. J Antimicrob Chemother 2008; 61: 436-41.

50. Kollef $\mathrm{MH}$. Inadequate antimicrobial treatment: an important determinant of outcome for hospitalized patients. Clin Infect Dis 2000; 31 Suppl 4: S131-8. 




\section{Samenvatting}



Een grote verscheidenheid aan bacteriën, virussen, schimmels en parasieten is verantwoordelijk voor de naar schatting 15 miljoen sterfgevallen per jaar als gevolg van infectieziekten. Infectieziekten gaan gepaard met een hoge morbiditeit en mortaliteit en vormen bijgevolg een hoge sociaal-economische last voor de maatschappij. De bestrijding van infectieziekten is complex en afhankelijk van verschillende aspecten, waaronder preventie, diagnose en behandeling.

Het slagingspercentage van de behandeling wordt beïnvloed door diverse factoren, waaronder de snelheid en de precisie van de diagnose en daarom zijn snelle en gevoelige methoden voor de diagnose van infectieziekten essentieel. Nieuwe diagnostische technieken moeten bijdragen tot het voorkomen van sterfgevallen en tot het verbeteren van de kwaliteit van leven. Bovendien is een snelle interventie cruciaal om verspreiding van de ziekte te voorkomen en om de ontwikkeling van resistente stammen van bepaalde ziekteverwekkers te vermijden. Hoewel de op kweek gebaseerde methoden algemeen beschouwd worden als de gouden standaard voor de detectie en identificatie van ziekteverwekkers, dragen deze ook nadelen zoals het (relatief) lange tijdsbestek tussen de afname van een patiëntstaal en het verkrijgen van de uitslag van het microbiologisch onderzoek van moeilijk groeiende microorganismen met zich mee. Moleculaire methoden bieden een alternatieve strategie, waarbij er zowel op niveau van eiwitten als nucleïnezuren wordt gezocht naar onderscheid tussen de verschillende soorten micro-organismen. Studies hebben aangetoond dat deze alternatieve methoden een verhoogde sensitiviteit en specificiteit bezitten, en daarnaast kunnen ze ook een aanzienlijke winst in tijd opleveren. Toch zijn er verdere studies en ontwikkelingen nodig om onder meer het gebrek aan onderscheid tussen dode en levende micro-organismen, en het gebrek aan een snelle bepaling van het antimicrobiële resistentie profiel te elimineren.

De studies uitgevoerd en beschreven in deze thesis zijn gericht op het ontwikkelen van moleculaire methoden voor de snelle diagnose van potentieel pathogene bacteriën en schimmels. Verschillende technieken, gaande van extractie tot detectie en identificatie van het bacteriële of fungale DNA, werden ontwikkeld, geoptimaliseerd en gevalideerd op verschillende klinische patiëntstalen.

\section{De extractie van bacterieel en fungaal DNA uit verschillende lichaamsvloeistoffen}

In de eerste studies werd er ingegaan op het belang van preanalytische methoden voor de selectieve extractie van microbieel DNA uit volbloed (hoofdstuk 2a, 2b). De implementatie van een snelle, moleculaire test biedt 
immers een aanzienlijke winst in tijd wanneer deze rechtstreeks toepasbaar is op volbloed. De detectiegrens van de meest optimale DNA extractie methode bedroeg 50 kolonievormende eenheden (kve) per $\mathrm{ml}$ volbloed. Zowel het elimineren van remmende substanties aanwezig in bloed, als het gebruiken van grotere volumes zorgden voor een toename van de sensitiviteit. Om na te gaan of deze detectiegrens geschikt is voor klinische stalen, werd de bacteriële concentratie onderzocht in pediatrische volbloedstalen. Voorheen werd er gesuggereerd dat de concentratie micro-organismen in het bloed hoger was bij kinderen dan bij volwassenen. Maar er bestaan echter ook tegenstrijdige bevindingen die wijzen op het voorkomen van zeer lage aantallen van microorganismen bij kinderen. Dit kan problematisch zijn omdat de diagnostische opbrengst direct gerelateerd is aan de hoeveelheid bloed die afgenomen wordt. Bij volwassenen is het aanbevolen om 20 tot $30 \mathrm{ml}$ bloed per bloedkweekfles af te nemen, maar bij kinderen bedraagt dit minder dan $10 \mathrm{ml}$. Tijdens ons onderzoek werden er lage aantallen bacteriën gevonden in bloedstalen van kinderen. In $85 \%$ van de stalen waren er minder dan 50 kve per $\mathrm{ml}$ bloed aanwezig, wat erop wijst dat onze geoptimaliseerde DNA extractie methode in deze gevallen geen ziekteverwekker zou aantonen. In conclusie, de combinatie van verschillende factoren d.w.z. groter bloed volume, het elimineren van remmende substanties (m.n. humaan DNA) en de verrijking van bacterieel DNA heeft geresulteerd in het verbeteren van de detectiegrens van bestaande DNA extractie methoden die worden aangewend voor de diagnose van ziekteverwekkers. Daarnaast hebben we aangetoond dat de bacteriële concentratie in kinderen net zoals bij volwassenen eveneens laag kan zijn, wat het gebruik van deze methoden voor de rechtstreekse detectie van microorganismen rechtstreeks uit volbloed belemmert.

\section{De detectie en identificatie van bacteriële en fungale micro- organismen}

Nadat het bacteriële of fungale DNA wordt geïsoleerd uit het patiëntstaal, kan het opgezuiverde materiaal gebruikt worden voor de volgende stap in de analyse, namelijk de precieze identificatie van de ziekteverwekker. Hiervoor worden moleculaire technieken zoals de polymerase ketting reactie (PCR) toegepast. Deze is gebaseerd op het vermenigvuldigen van het aanwezige DNA tot een analyseerbare concentratie. Deze methode is uitermate snel, en kan binnen enkele uren resultaten genereren, waardoor een snelle detectie van pathogenen mogelijk is. In een van onze studies werd er een PCR methode ontwikkeld om de meest voorkomende bacteriële ziekteverwekkers op te sporen in bloedkweken (Hoofdstuk 3a). De test was bestemd om in de eerste plaats een bacteriële infectie te diagnosticeren. Daarnaast is het mogelijk om met deze test de volgende micro-organismen te identificeren: Staphylococcus 
species, Staphylococcus aureus, Enterococcus species, Streptococcus species, Streptococcus pneumonia, Escherichia coli, Pseudomonas species en Pseudomonas aeruginosa. Er werden 248 bloedkweken onderzocht op aanwezigheid van bacteriën, en in $97 \%$ konden de resultaten van de referentiemethode (kweekgebaseerde identificatie) bevestigd worden met onze nieuwe identificatietest. De analyse met behulp van deze nieuwe methode neemt in totaal 2 uur in beslag, hetgeen een drastische verbetering betekent ten opzichte van de huidige bacteriële diagnostiek die 18 - 24 uur in beslag neemt.

Een soortgelijke test werd er ontwikkeld voor de diagnose van relevante schimmelinfecties, veroorzaakt door Candida species (Hoofdstuk 3b). Invasieve infecties met Candida species zijn geassocieerd met hoge sterftecijfers, variërend van $38 \%$ tot $74 \%$. In onze experimenten werden alle Candida-positieve bloedkweken correct geïdentificeerd op species niveau. Daarbij zijn we er met onze nieuwe methode in geslaagd om Candida albicans te identificeren in bloedkweken die als negatief werden beschouwd met de referentiemethode. Het is alom bekend dat schimmels vaak traag en moeilijk te kweken micro-organismen zijn, waardoor onze alternatieve, moleculaire methode een belangrijk voordeel oplevert ten opzichte van de kweekgebaseerde methode. Ook moleculaire methoden hebben in de loop der jaren een grondige evolutie doorstaan. In het verleden werd de PCR techniek voornamelijk gecombineerd met een tijdrovende sequentieanalyse van het bacteriële 16S rDNA gebied. Hier kwam recent verandering in door het op de markt brengen van commerciële kits zoals SeptiFast (Roche Diagnostics) en SepsiTest (Molzym) voor de analyse van bloedstalen. Deze methoden zijn bestemd voor de detectie van 25 tot 40 sepsis-gerelateerde pathogenen, en kunnen worden afgerond binnen de 6 tot 8 uur. Prove-It Sepsis (Mobidiag) is een gelijkaardig systeem voor de diagnose van 80 micro-organismen uit bloedkweken, en dit binnen de 3,5 uur. Hoewel deze veelbelovende technologieën een meer uitgebreid panel van micro-organismen aanbieden, en sommigen zelfs rechtstreeks kunnen worden toegepast op volbloedstalen, zullen studies hun mate van implementatie in routine diagnostiek nog moeten uitwijzen. Ondanks alle onderzoek is het duidelijk dat de huidige moleculaire technieken nog niet voldoende in staat zijn om de kweekgebaseerde referentiemethoden te vervangen.

Naast identificatie van de ziekteverwekker is het in bepaalde gevallen ook noodzakelijk om kennis te hebben over de mate van infectie, met andere woorden de hoeveelheid micro-organismen aanwezig in het patiëntstaal. In een studie waarbij we gekeken hebben naar urineweginfecties, hebben we getracht om zowel identificatie als kwantificatie van het micro-organisme te bewerkstellingen (Hoofdstuk 4). De bepaling van de hoeveelheid microorganismen is essentieel omdat verschillende afkappunten $\left(>10^{3}\right.$ of $\left.10^{5} \mathrm{kve} / \mathrm{ml}\right)$ worden gebruikt in combinatie met klinische symptomen als diagnose van 
urineweginfecties in verschillende bevolkingsgroepen. Het toepassen van de nieuwe moleculaire methode gebruik makende van de PCR laat ons toe om te categoriseren in: normale urine $\left(<10^{3} \mathrm{kve} / \mathrm{ml}\right)$, bacteriurie $\left(10^{3}-10^{4} \mathrm{kve} / \mathrm{ml}\right)$ en significante bacteriurie $\left(\geq 10^{5} \mathrm{kve} / \mathrm{ml}\right)$. Bovendien zou deze snellere screening van urinestalen ervoor zorgen dat identificatie met behulp van kweek gereduceerd wordt met $47 \%$.

In conclusie, de ontwikkeling van een snelle, sensitieve en specifieke real-time PCR methode heeft de identificatie en semi-kwantificatie van klinisch relevante bacteriën en schimmels uit bloedkweken en urine mogelijk gemaakt, en dit binnen de 2 uur. Er is echter nog wel behoefte aan klinische studies die de waarde (impact van m.n. reductie in tijd tot diagnose en versnelde bijstelling van therapie, hospitalisatieduur, complicaties,...) en rol van moleculaire methoden in het verbeteren en versnellen van zowel diagnose als behandeling van patiënten aantonen.

\section{De genotypische detectie van antibiotica resistentie in Staphylococcus species}

Veel studies in het verleden hebben zich toegelegd op het ontwikkelen van een snelle methode voor de identificatie van bacteriële en fungale infecties uit verschillende patiëntstalen. Toch is steeds de rol van de kweekgebaseerde referentiemethode prominent aanwezig gebleven, ten gevolge van het gebrek aan een alternatieve methode voor het bepalen van een antibiogram. Het ontwikkelen van een alomvattende genotypische test voor antibioticaresistentie wordt bemoeilijkt door het voorkomen van de grote hoeveelheid genen die betrokken zijn in de verschillende resistentiemechanismen. Eerdere studies gebruik makende van micro-arrays hebben laten zien dat deze technologie geschikt is voor dergelijke toepassingen. Het feit ook dat deze technologie een hoge capaciteit heeft, maakt hem aantrekkelijk voor dit type onderzoek. Vaak is deze micro-array technologie echter niet geschikt in termen van kosten, benodigde laboratoriumapparatuur en gebruiksvriendelijkheid.

In het laatste experimentele hoofdstuk hebben we getracht een PCR methode te ontwikkelen voor de bepaling van antibioticaresistentie in staphylococcen (Hoofdstuk 5). Een panel van de meest gevraagde en klinisch relevante antibiotica werden zowel genotypisch als fenotypisch bepaald. De resultaten voldeden aan de selectiecriteria (> 90\% categorische overeenkomst tussen referentiemethode en nieuwe test) opgesteld door Jorgensen, en waren beschikbaar binnen de 2 uur nadat een bloedkweek positief bevonden was. Het aanbieden van zowel identificatie van het micro-organisme als bepaling van resistentie kan de analyse sterk versnellen en stelt de aanvrager in staat de keuze van de juiste therapie te starten op een eerder tijdstip dan verkregen na de conventionele kweekgebaseerde methode. We moeten ons echter bewust 
zijn dat het onderzoek naar moleculaire methoden voor antibiotica resistentie bepaling zich in een beginstadium bevindt en dat nog meer studies vereist zijn wat betreft resistentiemechanismen en antibiotica resistentie determinanten. Toch bestaan er reeds enkele voorbeelden van genotypische testen die reeds in de kliniek toegepast worden zoals de detectie van het mecA gen, karakteristiek voor methicilline-resistente Staphylococcus aureus (MRSA). De verwachting is dan ook dat dit in de toekomst voor meerdere resistente microorganismen het geval zal zijn.

\section{Conclusie}

Samenvattend hebben onze bevindingen aangetoond dat moleculaire methoden voor wat betreft snelheid, sensitiviteit en specificiteit de huidige referentiemethoden kunnen overtreffen en zeker kunnen aangewend worden voor de detectie en identificatie van bacteriële en fungale micro-organismen. We hebben kunnen aantonen dat bepaalde elementen in het DNA extractie proces, met name grotere bloedvolumes, en het elimineren van humaan DNA, de detectiegrens van moleculaire testen drastisch kan verlagen. Daarnaast heeft de ontwikkeling van een identificatietest voor zowel klinisch relevante bacteriën als schimmels een snelle analyse (binnen één werkdag) van patiëntstalen zoals bloedkweken mogelijk gemaakt. Al deze verbeteringen moeten er op termijn toe leiden dat zowel de diagnose als de behandeling van patiënten met verdenking op infectie sneller verlopen, waardoor ook de morbiditeit en mortaliteit zal afnemen. Er zullen echter meer studies moeten uitgevoerd worden waarbij de implementatie van deze testen onderzocht wordt, en of het op termijn mogelijk zal zijn om patiëntstalen rechtstreeks te analyseren, zonder voorafgaande kweek. 



\section{List of publications}

Wendy LJ Hansen, Cathrien A Bruggeman, Petra FG Wolffs. Evaluation of new preanalysis sample treatment tools and DNA isolation protocols to improve bacterial pathogen detection in whole blood. Journal of Clinical Microbiology (2009) 47(8):2629-2631.

Wendy LJ Hansen, Judith Beuving, Cathrien A Bruggeman, Petra FG Wolffs. Molecular probes for diagnosis of clinically relevant bacterial infections in blood cultures. Journal of Clinical Microbiology (2010) 48(12):4432-4438.

Wendy LJ Hansen, Cathrien A Bruggeman, Petra FG Wolffs (2012). PCR Detection of Microbial Pathogens. In M. Wilks (Ed.), Methods in Molecular Biology. Totowa, NJ: Humana Press. In press.

Wendy LJ Hansen, Judith Beuving, Annelies Verbon, Petra FG Wolffs. One-day workflow scheme for bacterial pathogen detection and antimicrobial resistance testing from blood cultures. Accepted for publication in Journal of Visualized Experiments.

Wendy LJ Hansen, Christina FM van der Donk, Cathrien A Bruggeman, Ellen E Stobberingh, Petra FG Wolffs. A real-time PCR-based semi-quantitative breakpoint to aid in molecular identification of urinary tract infections. Submitted for publication.

Wendy LJ Hansen, Judith Beuving, Cathrien A Bruggeman, Ellen E Stobberingh, Petra FG Wolffs. Genotypic antibiotic resistance determination of Staphylococci. Submitted for publication.

Wendy LJ Hansen, Judith Beuving, Cathrien A Bruggeman, Petra FG Wolffs.Pathogen diagnostics for bloodstream infections: bacterial load issues. In preparation.

Özlem Güven, Wendy LJ Hansen, Astrid Oude Lashof, Frank van Tiel, Cathrien A Bruggeman, Petra FG Wolffs. Rapid identification of Candida species in blood cultures by multiprobe TaqMan PCR assay. In preparation. 